IBERÊ ANSELMO GARCIA

A SEGURANÇA NA IDENTIFICAÇÃO:

A BIOMETRIA DA ÍRIS E DA RETINA

Dissertação apresentada no Departamento de Direito Penal, Medicina Forense e CRIMINOLOGIA

Orientadora Profa. Dra. IRENE BATISTA MUAKAD

FACULDADE DE DIREITO DA USP

SÃO PAULO, 2009 
IBERÊ ANSELMO GARCIA

\section{A SEGURANÇA NA IDENTIFICAÇÃO: \\ A BIOMETRIA DA ÍRIS E DA RETINA}

Dissertação apresentada no Departamento de Direito Penal, Medicina Forense e Criminologia da Faculdade de Direito da Universidade de São Paulo, como requisito parcial para obtenção do título de Mestre, sob a orientação da Profa. Dra. Irene Batista Muakad

\section{FACULDADE DE DIREITO DA USP}

SÃO PAULO, 2009 
Para MÔNICA, meu amor, meu exemplo para esta e tantas outras realizações.

Para ANA CAROLINA e RODRIGO, motivos de minhas maiores alegrias.

Em memória de meu pai, JOÃO BAPTISTA GARCIA FILHO, que me ensinou a gostar de aprender. 


\section{AGRADECIMENTOS}

À Professora IRENE BATISTA MUAKAD, pelos preciosos conselhos e orientação.

Aos professores do DEPARTAMENTO DE DIREITO PENAL, MEDICINA FORENSE E CRIMINOLOGIA do glorioso Largo São Francisco, que nas disciplinas cursadas na pósgraduação indicaram os caminhos a percorrer.

Aos meus familiares, amigos e colegas de pós-graduação pelo apoio durante a elaboração deste trabalho. 


\section{SUMÁRIO}

INTRODUÇÃO 1

PARTE I

IDENTIDADE E IDENTIFICAÇÃO

CAPÍTULO I - IDENTIDADE 4

1.1. IDENTIDADE COMO CONCEITO FILOSÓFICO ….....................................................

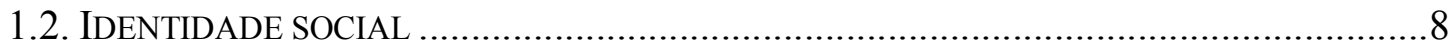

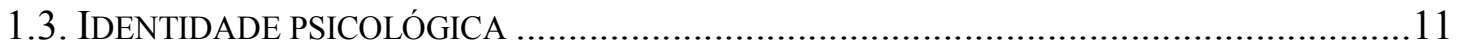

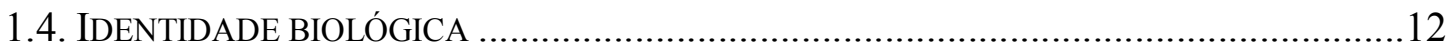

1.5. IDENTIDADE DA PESSOA DO PONTO DE VISTA JURÍDICO ..........................................16

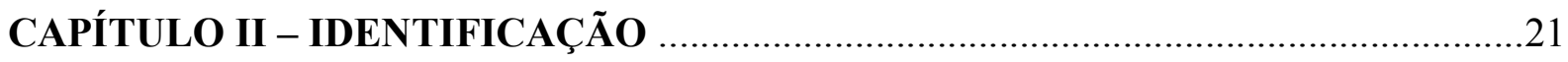

2.1. CONCEITO, CLASSIFICAÇÃO E REQUISITOS DE VALIDADE .......................................21

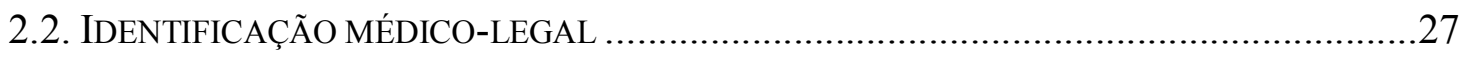

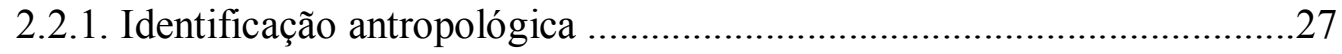

2.2.1.1. Identificação antropológica e identificação

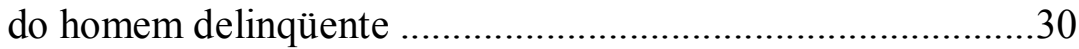

2.2.2. Identificação por marcadores sangüíneos e de histocompatibilidade .....32

2.2.3. Identificação pelo DNA ….....................................................................33

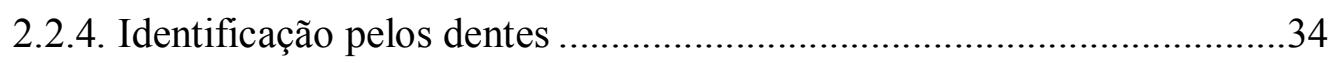

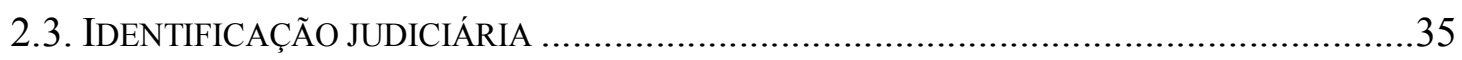

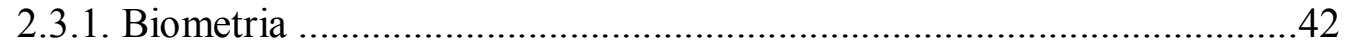

2.3.2. Biometria e ciências forenses ............................................................49

PARTE II

BIOMETRIA OCULAR - ASPECTOS TÉCNICOS

CAPÍTULO III - BASES BIOLÓGICAS PARA A BIOMETRIA OCULAR …............54

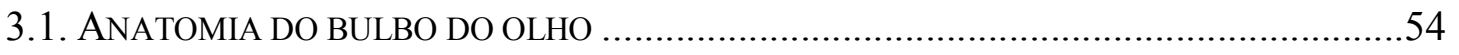

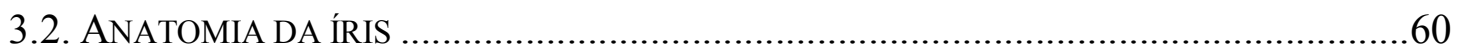

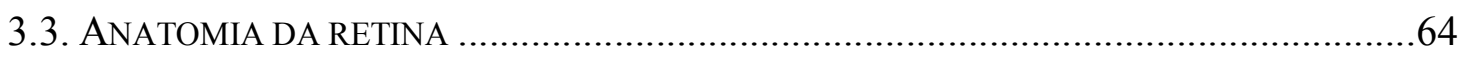

CAPÍTULO IV - BASES TECNOLÓGICAS PARA A BIOMETRIA OCULAR .........68

4.1. OBTENÇÃO E PROCESSAMENTO DA IMAGEM DAS ESTRUTURAS OCULARES PARA FINS

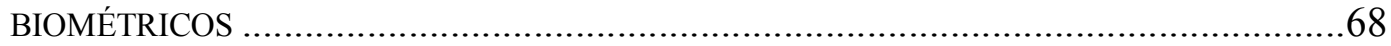

4.2. ANÁLISE INFORMÁTICA DOS DADOS BIOMÉTRICOS OCULARES ..............................71 
5.1. TIPOS DE BIOMETRIA OCULAR .75

5.1.1. Biometria da íris .75

5.1.2. Biometria da retina 76

5.2. EQUIPAMENTOS UTILIZADOS NA BIOMETRIA OCULAR .78

5.3. MODO DE OPERAÇÃO DA BIOMETRIA OCULAR .84

5.4. UTILIZAÇÃO DA BIOMETRIA OCULAR 85

PARTE III

\section{BIOMETRIA OCULAR E PERÍCIA JUDICIAL}

\section{CAPÍTULO VI - PERÍCIA E BIOMETRIA OCULAR} 87

6.1. PERÍCIA DA IDENTIDADE PELA BIOMETRIA DAS ESTRUTURAS OCULARES ..................88

6.2. PERÍCIA DA VALIDADE DO SISTEMA DE IDENTIFICAÇÃO BIOMÉTRICO .......................91

6.3. IDENTIFICAÇÃO CIVIL E CRIMINAL E BIOMETRIA OCULAR 93

\section{CAPÍTULO VII - UTILIZAÇÃO DA BIOMETRIA OCULAR COMO MEIO}

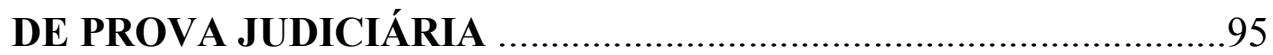

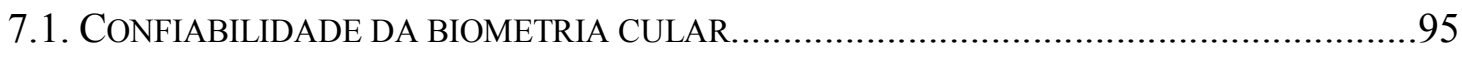

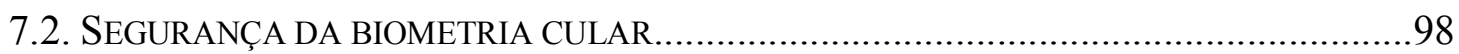

CAPÍTULO VIII - PRIVACIDADE E BIOMETRIA OCULAR .................................102

CONCLUSÃO

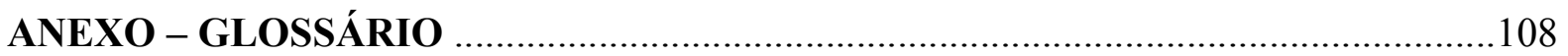

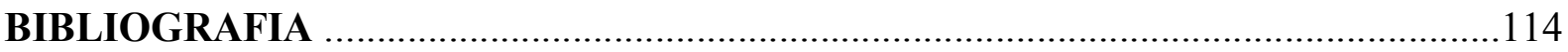

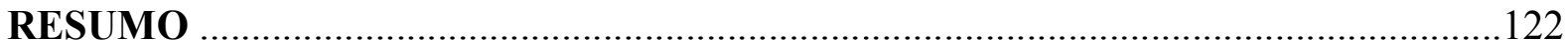

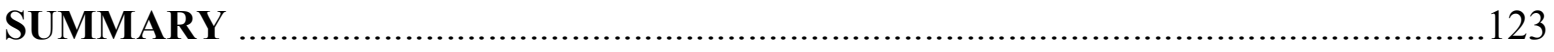




\section{INTRODUÇÃO}

A identificação humana sempre foi uma necessidade e um desafio. Do reconhecimento de um indivíduo entre os seus semelhantes pode depender a segurança em uma transação comercial ou a segurança de um grupo de pessoas contra um agressor. Ser identificado é essencial para ter seus direitos reconhecidos. Identificar alguém é também essencial para exigir dele o cumprimento de um dever. Seja para um homem, seja para uma instituição, identificar as pessoas significa relacionar-se com segurança.

Identifica-se alguém por características de seu corpo. O homem como organismo vivo ou morto distingue-se como indivíduo por características biológicas, ai incluídos os padrões de comportamento e resposta a estímulos externos. A história de seus hábitos e atividades escreve-se em seu corpo servindo também para seu reconhecimento. Confiando na permanência de algumas características ao longo do tempo, civilizações antigas ou mais recentes marcaram os corpos de alguns para serem mais facilmente reconhecidos posteriormente.

A Medicina Legal sempre se ocupou da identificação do homem, suas partes, seus restos mortais. As formas de realizar essa identificação evoluiram lado a lado à evolução tecnológica nas diferentes épocas. Se no passado marcava-se a pele para identificação de condenados ou escravos, hoje, pela análise molecular pode-se reconhecer um corpo ou um indivíduo.

Em uma sociedade informatizada em que decisões importantes podem ser tomadas em segundos e as comunicações aproximam os indivíduos sem considerar as distâncias, novas formas de identificação fizeram-se necessárias. A própria tecnologia da informação e a eletrônica forneceram as respostas para essa necessidade, com a criação das técnicas de biometria.

Biometria é a ciência do reconhecimento da identidade de alguém por meio de atributos físicos ou comportamentais, como a face, impressões digitais, voz e íris utilizando para isso tecnologia eletrônica e recursos informáticos. A utilização de técnicas biométricas tem sido cada vez maior, como por exemplo, em documentos de identidade nacional e internacional, controle de acesso físico ou de dados, controle da identidade para 
fins de transações comerciais, finalidades criminais e etc. As evoluções desse campo acompanham o ritmo de evolução da tecnologia contemporânea, ou seja, são extremamente aceleradas.

Entre as técnicas de biometria encontram-se as que se baseiam em atributos oculares como as características da íris e da retina. Sobretudo a primeira, a biometria da íris, tem encontrado uma utilização cada vez mais freqüente no dia a dia do cidadão comum, e tende a ter cada vez maior utilização prática.

A presente dissertação procura estudar a biometria ocular, suas técnicas, características, aplicações, limitações e, sobretudo sua confiabilidade e sua segurança para aplicações jurídicas. O trabalho está dividido em três partes. Na primeira, serão estudados o conceito de identidade em seus diversos significados (Capítulo I) e as técnicas de identificação e sua evolução histórica até as técnicas biométricas (Capítulo II). Na segunda parte, discorrer-se-á sobre a biometria ocular, abordando suas bases anatômicas e tecnológicas (Capítulos III e IV) e sua operacionalização (Capítulo V). A terceira parte referese à relação entre biometria ocular e perícia judicial (Capítulo VI), sendo abordadas questões concernentes à utilização da biometria ocular como meio de prova judiciária (Capítulo VII) e à proteção da privacidade frente a essas novas possibilidades (Capítulo VIII). Seguem, finalmente, as conclusões, um anexo contendo o glossário e a bibliografia. 
PARTE I

IDENTIDADE E IDENTIFICAÇÃO 


\section{CAPÍTULO I. IDENTIDADE}

Identidade deriva do latim Idem que significa "o mesmo". O termo chegou às línguas neolatinas por meio do latim tardio identicu, (idêntico) ${ }^{2}$. Identidade é definida como "a qualidade do idêntico", ou seja, a qualidade de cada um de dois ou mais conceitos iguais entre si.

Para Aurélio, a qualidade de "ser o mesmo" ou a "mesmice" (como a chamava Odon Ramos Maranhão ${ }^{3}$ ) "é o conjunto dos caracteres próprios e exclusivos de uma pessoa" ou "o conjunto das características pelas quais algo é definitivamente reconhecível ou conhecido".

Essa definição destaca dois aspectos do conceito de identidade. A identidade deriva do conjunto de características exclusivas e próprias de alguma coisa e esse conjunto permite o seu reconhecimento "definitivo" ou seguro. Os seres vivos, como é fácil concluir, identificam-se primeiramente por características biológicas. Os seres humanos identificam-se por seus nomes, por sua idade, sexo, aspectos físicos e orgânicos que lhes são próprios e exclusivos.

Para a Medicina Legal a identidade de uma pessoa é um tema importante. Odon Ramos Maranhão definia identidade como "o conjunto de propriedades que tornam alguém essencialmente diferente de todos os demais, com quem se assemelhe ou possa ser confundido". Para Hermes Rodrigues de Alcântara identidade "é o conjunto de caracteres físicos, funcionais e psíquicos, natos ou adquiridos, porém, permanentes, que fazem com que uma pessoa seja ela mesma e não outra" ${ }^{5}$. Almeida Júnior salienta que o "conceito de identidade abrange dois elementos: a unicidade e a imutabilidade" Fávero $^{7}$ conceitua identidade como o conjunto de "propriedades, sinais, marcas que

\footnotetext{
${ }^{1}$ Identidade: In: André LALANDE, Vocabulário técnico e crítico da filosofia, p. 504.

${ }^{2}$ Identidade e idêntico in: Aurélio BUARQUE DE HOLANDA FERREIRA, Novo Aurélio século XXI, p. 1071.

${ }^{3}$ Curso básico de medicina legal, p. 53.

${ }^{4}$ Odon Ramos MARANHÃO, Curso básico de medicina legal, p. 53.

${ }^{5}$ Perícia médica judicial, p. 24.

${ }^{6}$ Lições de medicina legal, p. 11.

${ }^{7}$ Medicina legal, p. 62.
} 
caracterizam alguma coisa ou alguém, seja em vida, quer depois da morte". A maioria dos autores médico-legais tem definido identidade de maneira semelhante ${ }^{8}$.

Essas diversas definições demonstram que o termo identidade é polissêmico. Fala-se de identidade a partir de conceitos filosóficos, sociais, psicológicos, biológicos, médico-legais e jurídicos. Um breve estudo desses conceitos permite uma compreensão ampla do termo. É o que se verá a seguir.

\subsection{IDENTIDADE COMO CONCEITO FILOSÓFICO}

Em filosofia, a palavra identidade tem diversos significados. Identidade refere-se à situação em que dois conteúdos do pensamento correspondem a apenas um ser. Identidade também se refere ao fato de algo se manter idêntico a si mesmo apesar de ter sofrido diversas mudanças ao longo do tempo. É também o reconhecimento qualitativo de indivíduos de uma mesma espécie. Além disso, é sinônimo de igualdade relativa entre seres diferentes de um ponto de vista subjetivo. Serão abordados aqui alguns desses conceitos.

O conceito de "mesmo" é um conceito fundamental do pensamento. Por essa razão é impossível defini- $10^{9}$. Se identidade for definida como o fato de ser o mesmo, a definição se impõe como auto-evidente ${ }^{10}$. Algo é perfeitamente igual apenas a si mesmo, ou seja, só existe identidade nesse sentido se os seres que se comparam são um só. Essa é a definição de Aristóteles: os seres só são idênticos se forem unos em essência ou substância $^{11}$. De fato, por vezes, as coisas são percebidas ou nomeadas de diferentes maneiras, sendo, no entanto, claro que são o mesmo ser. Assim, refere-se ao planeta Vênus como Vésper, Estrela da Manhã, Estrela Dalva, mas reconhece-se a unidade do ser além da multiplicidade de nomes ${ }^{12}$. Deriva-se desse conceito o Princípio da Identidade, que é enunciado como "toda coisa (ser) é idêntica a si mesma. O que é, é; o que não é, não é" ${ }^{13}$.

\footnotetext{
${ }^{8}$ Para Hélio Gomes, "identidade é a soma de caracteres que individualizam uma pessoa, distingüindo-a das demais" Medicina legal, p.45, para CROCE, "identidade o conjunto de caracteres próprios e exclusivos das pessoas, dos animais, das coisas e dos objetos. É a soma de sinais, marcas e caracteres positivos e negativos que, no conjunto, individualizam o ser humano ou uma coisa, distinguindo-a dos demais" p.36.

${ }^{9}$ Identidade in: André LALANDE, Vocabulário técnico e crítico da filosofia, p. 504.

10 “Identité: Le fait d'etre le même. Mais le même de quoi? Le même que le même: il n'y aurai pás autrement identité. Ainsi l'identité est d'abord une relation de soi a soi".André COMTE-SPONVILLE, Dictionnaire philosophique, p. 289.

${ }^{11}$ Identidade in: Nicola ABBAGNANO, Dicionário de filosofia, p. 528.

${ }^{12}$ Identidade in: André LALANDE, Vocabulário técnico e crítico da filosofia, p. 504; André COMTESPONVILLE, Dictionnaire philosophique, p. 289.

${ }^{13}$ Alaôr Caffé ALVES, Lógica, p. 150-151.
} 
Deste mesmo princípio lógico derivam outros, como o da contradição, o princípio do terceiro excluído, o princípio do terceiro equivalente e o princípio de capacidade ${ }^{14}$.

Por outro lado, no segundo sentido, identidade é a qualidade do indivíduo $^{15}$ (ou do objeto do pensamento) que o torna idêntico a si próprio nos diversos momentos de sua existência, "não obstante as mudanças por vezes consideráveis que podem nele acontecer ${ }^{16}$ ". Diz-se, assim, que o autor de Dom Casmurro é o mesmo que o de Memórias Póstumas de Brás Cubas, embora quase vinte anos separem o surgimento das duas obras. Ou que a cidade que abriga hoje o Congresso Nacional é a mesma Brasília fundada em 1960 por Juscelino Kubitschek, em que pesem as mudanças que sofreu desde então. Ou ainda, que aquelas folhas envelhecidas são o mesmo documento que a Princesa Regente assinou ao sancionar a Lei Áurea.

Esses dois conceitos de identidade são conhecidos como identidades numéricas. Nos dois casos trata-se de um só ser que é objeto do pensamento de maneiras diferentes sem que se perca a unidade de sua essência ${ }^{17}$. Lalane et al. ${ }^{18}$ criticam essa denominação porque para eles o termo é "equívoco". Esses autores preferem referir-se à permanência do ser ao longo do tempo como identidade temporal ou identidade jurídica, reservando o termo identidade numérica para o reconhecimento do mesmo ser sob diferentes denominações.

Identidade também pode ser igualdade. Diz-se que dois seres são idênticos ou iguais se podem substituir-se sem conseqüências significativas. Se A é igual a B, e $\mathrm{A}+\mathrm{C}=\mathrm{D}, \mathrm{B}+\mathrm{C}$ também é igual a $\mathrm{D}$. Esta é a identidade qualitativa ou específica. A identidade qualitativa é convencional, porque qualquer critério pode ser utilizado para estabelecê-la. É a experiência e percepção humanas que sugerem a identidade qualitativa ao pensamento. Por exemplo, quando se diz que duas pessoas têm o mesmo carro, quer-se dizer

\footnotetext{
${ }^{14}$ O princípio da contradição ou da não-contradição afirma que "duas proposições contraditórias não podem ser verdadeiras nem falsas ao mesmo tempo". O do terceiro excluído ou da alternativa lógica, afirma que "duas proposições contraditórias não podem ser as duas, ao mesmo tempo, falsas". O princípio do terceiro equivalente afirma que "duas coisas idênticas a uma terceira são idênticas entre si". O princípio de capacidade afirma que "tudo o que contém uma coisa contém seu conteúdo". Ver Alaôr Caffé ALVES, Lógica, p. 151 a 155.

${ }^{15}$ Identidade como fenômeno entre indivíduos da mesma espécie exige a compreensão do termo indivíduo. Entende-se por indivíduo o que não pode ser dividido. Corresponde à idéia de singular em oposição ao genérico, universal. Do ponto de vista biológico, é o ser vivo cujas partes atuam em coordenação, dependendo a sua existência desse fato. Ou seja, se as partes que mantém o organismo vivo deixam de atuar em sinergia, este desaparece. Assim, indivíduo de uma determinada espécie representa as unidades mínimas desse grupo, estável o bastante para ser reconhecido como pertencendo a espécie, estando esse conceito ligado a propriedade de manter-se vivo.

${ }^{16}$ Identidade in: André LALANDE, Vocabulário técnico e crítico da filosofia, p. 504.

${ }^{17}$ Identité in: André COMTE-SPONVILLE, Dictionnaire philosophique, p. 290.

${ }^{18}$ Identidade in: André LALANDE, Vocabulário técnico e crítico da filosofia, p. 506-507.
} 
que ambas possuem automóveis da mesma marca, mesmo modelo, mesmo ano de fabricação, cor, e etc., mas evidentemente, fala-se de dois objetos distintos. Diz-se que João é igual a Pedro em suas posições políticas, apesar de inúmeras outras diferenças que possa haver entre eles. É claro que, nesse exemplo, João só é igual a Pedro se não se exigir na comparação nada além da opinião política, pois se vistos mais atentamente, as diferenças entre eles os tornam cada vez mais semelhantes e menos idênticos ${ }^{19}$.

A primeira das acepções filosóficas de identidade segundo a qual identidade é a propriedade do "mesmo" tem relevância puramente especulativa. A essência do ser é inatingível para a razão humana. Assim também, o conceito de mesmo, como já foi dito acima, é indefinível. As outras acepções, no entanto, aproximam-se do senso comum da identidade no plano concreto. Para a razão humana, a concretização da identidade se origina da multiplicidade e variabilidade dos seres. Há seres vivos se houver os sem vida, há seres humanos se houver seres que não são humanos. Por isso, ao se falar em identidade, também se refere à diferença.

Cabe aqui discutir a relação entre identidade e diferença. A identidade é um conceito percebido pelas comparações entre os seres. Só se pode identificar uma mulher em relação ao conjunto de indivíduos que não são mulheres. Quando se diz "ele é argentino", também está se dizendo que ele não é um brasileiro, não é um boliviano e etc. Os seres são, portanto, identificados tanto por caracteres afirmativos como pelos negativos. A impressão mais forte, a princípio, parece ser que a identidade determina a diferença, já que a identidade designa a natureza da coisa. Entretanto, o processo de identificação de algo se inicia com o reconhecimento das diferenças deste com os demais. Se não houver características distintas entre eles estes são indistinguíveis. Por essa razão, a identidade surge no mesmo momento em que a diferença aparece. Outro exemplo: ninguém sente a necessidade, senão em raras situações, de declarar-se ser humano, já que esta característica é comum a todos os seres que se comunicam ${ }^{20}$.

Além de simultâneos, os conceitos de identidade e diferença são construídos pela linguagem. Já que a linguagem confunde-se com cultura, pode-se dizer que identidade e diferença são produtos culturai ${ }^{21}$. Não existe nenhuma identidade baseada

\footnotetext{
${ }^{19}$ Identidade in: André LALANDE, Vocabulário técnico e crítico da filosofia,p. 506.

${ }^{20}$ Tomaz T. da SILVA, A produção social da identidade e da diferença in Identidade e diferença, p.76. No entanto, há quem defenda a proeminência da identidade sobre a diferença do ponto de vista conceitual, já que a diferença pura é impensável. Ver crítica de L. BOISE em Identidade in: André LALANDE, Vocabulário técnico e crítico da filosofia, p.505.

${ }^{21}$ Tomaz T. da SILVA, A produção social da identidade e da diferença in Identidade e diferença, p.76.
} 
exclusivamente em caracteres naturais, essenciais ao ser, já que estes caracteres são filtrados pela nossa percepção e julgamento. Mesmo as identidades construídas a partir de características biológicas são construtos sociais. Tome-se como exemplo as raças no Brasil. Há muita miscigenação, e algumas pessoas que são consideradas da raça negra em alguns lugares são vistas como da raça branca em outros. Há ainda os que se dizem negros ou brancos sem que as demais concordem unanimemente com essa identidade ${ }^{22}$.

As identidades são assim marcadas pelos símbolos lingüísticos e culturais $^{23}$. São também, portanto, influenciadas pelo controle social. Vale dizer, sofrem influência dos mecanismos de poder na sociedade. Tanto a normalidade quanto os critérios de diferenciação são construídos sob o ponto de vista dos grupos ou das opiniões dominantes ${ }^{24}$. Em sociedades excludentes, é natural que as diferenças sirvam por vezes para justificar a exclusão social de alguns. Ocorrem também mecanismos de exclusão dentro dos grupos, agindo, nesse caso, para que seus membros rejeitem os que não pertencem a ele.

Refletindo sobre o mecanismo da formação da identidade a partir das diferenças, deve-se questionar se em toda determinação de uma identidade não há na verdade uma dose de poder excludente embutido no processo. Essa reflexão parece pertinente mesmo com relação a processos de identificação aparentemente baseados em critérios objetivos, como os envolvidos na determinação da identidade biológica ou especulativa.

\subsection{IDENTIDADE SOCIAL}

Em seus contatos sociais cada pessoa assume um determinado "status" em relação aos demais. Esse "status" inclui, mas não se limita aos papéis que o indivíduo desempenha. Na escola, os professores são reconhecidos como tais pelos alunos, mas ao mesmo tempo um professor pode freqüentar um curso e ser, naquele momento, um aluno. Alguém pode ser reconhecido como pertencente a uma determinada classe social, e ser tratado de uma certa forma pelos demais da mesma classe e pelos das outras. $\mathrm{Na}$ verdade, o reconhecimento da posição social é feito tanto pelo indivíduo como pelos demais, podendo em certos casos ocorrer discrepâncias. Por exemplo, alguém pode pretender fraudulentamente ter muitas posses, por alguma razão e passar como uma pessoa rica para outras pessoas. Outra

\footnotetext{
${ }^{22}$ O sistema de cotas em vestibulares e concursos para alguns grupos raciais tem adotado o critério da autoclassificação racial do candidato o que vem causando diversos problemas justamente pela falta de consenso dessa classificação dentro da sociedade brasileira. Ver Maria Rosário G.de CARVALHO, Breves reflexões suscitadas pelo artigo... "Horizontes antropológicos" vol. 11 nº 23 jan/jun 2005 p. 264-267.

${ }^{23}$ Tomaz T. da SILVA, A produção social da identidade e da diferença in Identidade e diferença, p. 81-83.

${ }^{24}$ Ibid., p. 76.
} 
pessoa, por outro lado, apesar de ter posses, pode não ter esse status reconhecido pelos outros em razão de símbolos não confirmadores de sua condição, tais como vestimentas ou posturas.

Identidade social, assim, é o conjunto dos atributos dos participantes em determinado contexto social que são reconhecidos e/ou assumidos pelos agentes na relação. Este conceito implica uma grande variabilidade da identidade social. Em um determinado contexto um indivíduo é cliente de alguém em um estabelecimento comercial, podendo, logo a seguir, em outro estabelecimento, tornar-se o comerciante e atender o comerciante que o atendia anteriormente como seu cliente.

Goffman salienta que as identidades sociais são veículos de expectativas de comportamento nas relações, já que o reconhecimento do "status" dos agentes coordena suas ações ${ }^{25}$. Um dos agentes pode ocultar ou procurar minimizar uma característica indesejada ou negativa que possua dos demais participantes para que seja obtido um dado resultado. Assim, este autor classifica as identidades sociais como virtuais e reais. As virtuais são as identidades que se baseiam nas expectativas geradas pelas preconcepções que todos trazem de suas experiências e aprendizagem passados. As reais são aquelas que os indivíduos provem efetivamente possuir ao longo da interação, seja esta momentânea ou duradoura.

Dessa forma, um indivíduo bem vestido e com vocabulário refinado pode ser considerado uma pessoa de boa posição social e de bom nível intelectual, recebendo tratamento condizente com esses atributos na relação. Porém, ao longo desta, é possível que seus reais atributos surjam, desnudando um indivíduo diferente desse estereótipo, que por alguma razão, quer passar uma impressão mais aceitável socialmente naquele momento. Dessa forma, se o indivíduo possui algum atributo considerado negativo por consenso naquele grupo social, é possível que quem o possua tente dissimulá-lo. É o indivíduo chamado de desacreditável por Goffman, em oposição ao desacreditado, que não consegue ocultar seus atributos negativos, chamados pelo autor estigmas ${ }^{26}$.

Como parte da identidade social, as instituições e organizações conferem aos indivíduos papéis, que são funções que eles assumem diante de determinadas instituições. Por exemplo, a família é formada dos pais, filhos, avós, tios e etc. que são papeis não excludentes que todos assumem ao longo da vida. Há também professores, alunos funcionários, responsáveis pelos alunos e outras funções exercidas em um ambiente escolar.

\footnotetext{
${ }^{25}$ Erving GOFFMAN, Estigma, p. 12-14.

${ }^{26}$ Ibid., p.12-14.
} 
O papel social é um importante elemento da expectativa gerada nas relações sociais, na medida e na razão direta da função desempenhada pelo indivíduo. Mas não é o único e muitas vezes não é o mais importante, porque os pais e professores diferem consideravelmente em seu desempenho social. Quanto ao desempenho de um papel por alguém, distinguem-se o papel prescrito e o papel desempenhado. O papel descrito é o comportamento padrão esperado do seu portador para cada função social. Já o papel desempenhado é o comportamento que alguém realmente assume nas interações sociais ${ }^{27}$. O desempenho pode desconfirmar o papel, como quando alguém diz "ele não é um pai de verdade". O papel prescrito faz parte da identidade social virtual e o desempenhado da identidade social real.

Como ficou claro e já foi dito, a identidade social é freqüentemente múltipla. Pode-se ser um professor, pai, fumante, jogador de basquete e devedor insolvente ao mesmo tempo. Essa característica da identidade social a torna diferente da identidade considerada como as características únicas, imutáveis e reconhecíveis de qualquer coisa. A identidade conferida pelas instituições oficiais do Estado procura elementos de estabilidade como os atributos físicos (traços biológicos que serão vistos adiante), o histórico de vida (cursos, cargos, estado familiar e etc.) e certamente ao reconhecer estes atributos estáveis para identificar o indivíduo, essa identidade "oficial” também contribui para a identidade social, ao gerar expectativas nos agentes que conhecem estes atributos identificadores. Apesar desses elementos mais estáveis a identidade social permanece variável e fluída, resultado de uma construção contínua e frágil ${ }^{28}$.

Castells diferencia a identidade definida pelas instituições, ou seja, o papel social, da identidade social que é reconhecida por cada indivíduo como sua própria identidade, no sentido de ser uma fonte de significado construída pelos autores sociais no processo de individuação, tratado a seguir. Este processo é realizado pela assimilação de elementos culturais obtidos pelos indivíduos na sociedade que ele próprio reconhece como seus. Tais elementos são a língua, os costumes, a etnia real ou criada de cada povo, a história comum e $\operatorname{etc}^{29}$.

A importância relativa dos papéis, da identidade pessoal e da identidade como identificação nos atos sociais depende de negociações infinitas dentro da

\footnotetext{
${ }^{27}$ Ana Mercês B. BOCK, Odair FURTADO e Maria de Lourdes T. TEIXEIRA, Psicologias, p. 139-140.

${ }^{28}$ Zygmunt BAUMAN, Identidade, p. 33-34.

${ }^{29}$ Ibid., p.23.
} 
sociedade. Tal fato é fonte de tensão para os indivíduos tanto com relação aos demais, quanto à sua auto-imagem ${ }^{30}$.

É no processo de individuação que a(s) identidade(s) social(is) participa $(m)$ da identidade psicológica, o que será visto a seguir.

\subsection{IDENTIDADE PSICOLÓGICA}

A identidade psicológica corresponde ao autoconceito, à resposta que cada um dá a si próprio ao perguntar-se "quem sou eu? ${ }^{31}$ ". É a percepção da permanência ao longo do tempo do núcleo dessa resposta. Faz parte dessa percepção, como já visto, a identidade social, mas também a história de vida de cada um, sua carga biológica enquanto organismo vivo e sua construção como indivíduo em um processo conhecido como individuação.

A individuação é o processo de tornar-se um sujeito, tornar-se um indivíduo. Em termos psicológicos é o processo de criar uma identidade. Essa identidade é o conjunto das representações e de sentimentos que cada um desenvolve a respeito de si próprio a partir de sua vivência. O palco dessa construção é a consciência de cada um, consciência aqui entendida como o saber que o homem adquire no mundo e o faz agir nele de determinada maneira $^{32}$.

A construção da identidade inicia-se com a descoberta do outro, em primeiro lugar a mãe e posteriormente seus outros parentes. É a chamada percepção social. Percebe o indivíduo o limite de seu corpo e, depois, de sua atividade na sociedade. Posteriormente, de acordo com sua cultura e língua, o indivíduo comunica-se com os demais e adquire uma experiência pessoal. Tudo isso o leva a adotar uma atitude, entendida como forma de agir até certo ponto previsível e que é determinada por sua individualidade $(\text { identidade) })^{33}$.

Nos encontros sociais a identidade psicológica assume um personagem dramático que desempenha o papel de alguém dentro de regras complexas

\footnotetext{
${ }^{30}$ Manuel CASTELLS, O poder da identidade, p. 22-23.

${ }^{31}$ Ibid., p. 22

${ }^{32}$ Ana Mercês B. BOCK, Odair FURTADO e Maria de Lourdes T. TEIXEIRA, Psicologias, p. 142-145.

${ }^{33}$ Ibid., p.135-138.
} 
assemelhadas no geral a uma representação teatral. A identidade social é parte desse papel, influenciando os atores e os personagens a partir das identidades psicológicas de cada $\mathrm{um}^{34}$

Como todo processo, a construção da identidade psicológica não é estática. Por essa razão, a identidade psicológica não é imutável. É um processo contínuo de representações da natureza pessoal de cada indivíduo ${ }^{35}$. Assim, a identidade psicológica, tal como a social, não se presta a uma identificação absoluta, mas apenas auxilia a identificação de um indivíduo por traços de seu comportamento.

Os seres vivos apresentam características que os distinguem entre si. É a identidade biológica, tratada a seguir, que fornece os atributos mais utilizados na identificação médico-legal e judiciária.

\subsection{IDENTIDADE BIOLÓGICA}

É observação intuitiva que os seres vivos agrupam-se em muitas espécies diferentes. O homem primitivo percebeu essas diferenças e desenhou em suas pinturas rupestres animais de diferentes espécies facilmente reconhecíveis. Também na Antigüidade já se tinha esta noção. No relato bíblico do Gênesis, Deus criou todas as espécies animais para cada ecossistema e ordenou ao primeiro homem que nomeasse cada ser vivo de acordo com sua vontade ${ }^{36}$. A identidade das espécies animais é estabelecida há séculos pelas características regulares que seus indivíduos apresentam. O mesmo pode-se dizer das espécies vegetais. Sabiam os antigos que animais da mesma espécie podiam cruzar entre si produzindo indivíduos com as mesmas características e que eram férteis.

Também por analogia consigo próprio o homem reconhecia entre os indivíduos da mesma espécie variações capazes de distinguir um determinado animal de outro. No Gênesis, há referência de um sinal físico que foi colocado sobre Caim para que este fosse reconhecido por todos em castigo pelo homicídio que cometeu. Em outra passagem bíblica, Jacó distinguia pelas características físicas seus cordeiros e suas cabras dos animais de seu sogro. Os antigos hebreus escolhiam os animais a serem sacrificados no templo pelas características físicas que demonstravam um critério de pureza ${ }^{37}$.

\footnotetext{
${ }^{34}$ Erving GOFFMAN, A representação do eu na vida cotidiana, p. 9-10.

${ }^{35}$ Ibid., p. 145.

${ }^{36}$ Gênesis 1,11 e 12, 20-25; 2,19

${ }^{37}$ Gênesis 4,15; 30, 32-46; Levítico 22, 21-25.
} 
Comumente, tanto os animais quanto os indivíduos eram identificados por marcas em seus corpos, fossem marcas adquiridas ou marcas congênitas. Assim, os escravos recebiam marcas de sua condição e da identidade de seus donos, os que transgrediam as leis podiam receber marcas a ferro quente, o chamado ferrete. Ainda na Antigüidade foram utilizadas diversas formas de mutilação para se identificarem os $\operatorname{criminosos}^{38}$. Bentham propôs que os apenados recebessem uma tatuagem que os identificasse (sistema dermográfico) $)^{39}$. A permanência dessas marcas no organismo dos assim assinalados garantia sua identificação futura.

A identidade biológica baseia-se, portanto, em dois princípios: o da individualidade e o da permanência. O princípio da individualidade anuncia que todos os seres de uma espécie não são absolutamente idênticos entre si, em razão da variabilidade da herança que recebem e das diversas influências do meio que seus organismos sofrem ${ }^{40}$. Pelo princípio da permanência, por sua vez, algumas dessas características apresentam-se de forma mais ou menos permanente no organismo ao longo dos anos, por mais que surjam mudanças pela passagem do tempo nesses indivíduos ${ }^{41}$. Na verdade, como se verá, o princípio da permanência está implícito no princípio da individualidade biológica.

O princípio da individualidade biológica é derivado do próprio conceito de um indivíduo sob o ponto de vista biológico, já exposto acima ${ }^{42}$. Em geral, distingue-se um indivíduo em relação ao todo, ao universal. Já ao individualizar um ser, a razão descobre particularidades dele em relação aos demais seres do grupo. Um espécime distingue-se sempre dos demais membros da espécie. Para ser considerado um indivíduo biológico, o ser vivo deve ter estruturas ou partes internas que agem de forma coordenada e que não têm existência independente do conjunto; deve manter-se em uma forma relativamente estável ao longo do tempo e ter ainda um período de existência definido, ou seja, deve nascer, crescer e morrer. É fácil deduzir dessas características que um indivíduo de uma espécie biológica só pode ser assim considerado se se mantiver inalterado em algum aspecto ao longo do tempo, até sua desagregação ${ }^{43}$.

\footnotetext{
${ }^{38}$ Adriano R. L. FIGINI e José Roberto L. e SILVA, Identificação Humana, p.137 - 141.

${ }^{39}$ Eduardo R.A. DEL-CAMPO, Medicina Legal, p.58.

${ }^{40}$ Karla CHEDIAK, O problema da individuação na biologia à luz determinação da unidade de seleção natural in Scientle studia, v.3 n1 p. 67-68.

${ }^{41}$ Eduardo R.A. DEL-CAMPO, Medicina Legal, p.139.

${ }^{42}$ Ver nota 15.

${ }^{43}$ Karla CHEDIAK, O problema da individuação na biologia à luz determinação da unidade de seleção natural in Scientle studia, v.3 n1 p. 67-68.
} 
No passado, a individualidade biológica era atribuída à forma de transmissão dos caracteres hereditários. De fato, para Aristóteles a hereditariedade dos caracteres biológicos era produto da influência tanto do pai quanto da mãe. Estas contribuições, segundo ele, ocorriam por uma mistura de "sangues". Para ele o sêmen é sangue purificado, sendo a fonte da vida e da forma (causa formal), enquanto o sangue feminino seria menos puro, participando apenas da matéria do embrião (causa material) ${ }^{44}$. $\mathrm{O}$ indivíduo seria formado assim, por contribuições de cada um dos pais em proporções diferentes, tendendo o indivíduo a ter maior semelhança com o genitor que mais contribuiu para a formação do embrião. O que determinaria a proporção da contribuição de cada genitor seriam fatores como temperatura, momento da concepção, e etc. Tantos fatores diferentes explicariam a variabilidade imensa entre os seres vivos ${ }^{45}$.

Além disso, Aristóteles acreditava que a permanência dos caracteres dos seres vivos ao longo do tempo seria explicada pelas suas causas, especificamente a causa formal e causa final. A causa formal é o princípio que leva cada ser a assumir determinada forma de acordo com sua natureza e posição na harmonia do cosmo. A causa final explica a finalidade do ser no universo. Assim, para cumprir sua finalidade e manter sua forma no cosmo, os seres apresentam uma permanência geral de suas características.

Somente no século XIX é que se iniciou, com Gregor Mendel, o estudo científico da hereditariedade. Descobriu-se que os gametas masculinos e femininos continham os genes, estruturas responsáveis pela transmissão das características herdadas, de diversos tipos, passando-se a entender as variações individuais dos organismos como expressão das inúmeras combinações possíveis entre os diferentes tipos de gametas existentes ${ }^{46}$.

\footnotetext{
${ }^{44}$ As quatro causas para Aristóteles são a causa material, formal, eficiente e a final. A causa material refere-se à substância ou aproximadamente ao tipo de matéria de que é constituído o ser. A causa formal corresponde à configuração do ser. Para o filosófo, a forma é que define o ser e não a "matéria". Daí a maior importância da participação masculina na geração dos seres. Betrand RUSSEL, História do pensamento ocidental, p. 111-112. ${ }^{45}$ Sérgio Danilo PENA, Aristóteles, nosso contemporâneo in Ciência Hoje in http://www.cienciahoje.uol.com.br/54575 acesso em 23/03/2007.

${ }^{46} \mathrm{Na}^{\mathrm{a}}$ edição do livro Lições de Medicina Legal, de A.ALMEIDA JÚNIOR, que é de 1953, lemos o seguinte na p.11, "Na maturação das células reprodutoras masculinas de cada homem, existe a possibilidade de formação de 16.777.216 tipos diferentes de espermatozóides; o que quer dizer que não serão muito comuns, no mesmo homem, os espermatozóides iguais...também na mulher ocorre a possibilidade de 16.777.216 óvulos diferentes...Ora, cada um dos 16.777.216 tipos de espermatozóides poderá combinar-se, ao acaso, com qualquer dos 16.777.216 tipos possíveis de óvulos, para formar um ovo-ovo esse que poderá, assim, pertencer a um de tantos tipos quantos os contidos no produto do número de espermatozóides pelo de óvulos...aproximadamente trezentos trilhões".
} 
Posteriormente, foram desvendadas as estruturas químicas de cada produto orgânico, o que permitiu o estudo mais rigoroso das estruturas celulares. Marcadores moleculares da superfície celular que variam em cada tipo de célula foram descobertos, (sistema HLA), permitindo o conhecimento íntimo da distinção entre todas as células e tecidos ${ }^{47}$. Essas características que, por meio de infinitas combinações, tornavam cada ser diferente dos demais no nível elementar da matéria, confirmaram o princípio da individualidade biológica.

Já no século XX, a descoberta do papel dos ácidos nucléicos na hereditariedade, a individualização dos cromossomos e o estudo morfológico dos genes foram etapas que permitiram que o DNA fosse reconhecido como a substância orgânica responsável pela transmissão das características hereditárias. Estudando-se a molécula de DNA, desvendou-se o código genético, conhecimento que esclareceu as bases moleculares da hereditariedade e dos fatores envolvidos na individualidade biológica. Principalmente, demonstrou-se de forma científica a impossibilidade de repetição exata de cada indivíduo, exceção feita aos gêmeos univitelinos e a certos organismos unicelulares, sendo também estabelecidas as bases para a permanência das características biológicas durante a vida.

O papel do meio ambiente, que de forma intuitiva há muito tempo tinha sido percebido, passou a ser mais bem compreendido, já que esse fator também participa na configuração final de cada ser vivo. No caso dos gêmeos univitelinos, que apresentam mesmos genes, as diferenças surgem principalmente devido a fatores ambientais. A exteriorização das determinações genéticas de um indivíduo, que se denomina genótipo, sofre a influência do meio-ambiente e fatores externos, resultando nas características individuais do ser biológico, produto que é chamado fenótipo.

A individualidade biológica surge da interação do genótipo singular de cada ser vivo com o meio ambiente. A singularidade genética não é suficiente para explicar totalmente a individualidade biológica, mas certamente hoje é reconhecida como seu elemento mais importante ${ }^{48}$.

Na verdade, o processo de formação de cada ser vivo a partir de sua herança genética e da influência ambiental é um processo estocástico e não completamente determinístico, o que o torna sujeito a variáveis aleatórias múltiplas causadoras de um produto

\footnotetext{
${ }^{47}$ Sérgio Danilo PENA, Pequena história da individualidade genética in Ciência Hoje in http://www.cienciahoje.uol.com.br/59470 acesso em 24/03/2007.

${ }^{48}$ Ibid. passim.
} 
final virtualmente impossível de se repetir, mesmo no caso de seres com a mesma carga genética, como os gêmeos univitelinos ${ }^{49}$.

Os procedimentos de determinação da identidade dos indivíduos do ponto de vista jurídico baseia-se em procedimentos de reconhecimentos de seu fenótipo e de sue genótipo. Como exemplos de determinação do fenótipo temos as técnicas datiloscópicas, biométricas, e odontológicas e como exemplos de técnicas que estudam o genótipo temos as análises sanguíneas e de DNA.

\subsection{IDENTIDADE DA PESSOA DO PONTO DE VISTA JURÍDICO}

A importância de se estabelecer a identidade dos indivíduos na sociedade é facilmente percebida. A segurança dos atos e negócios jurídicos depende da comprovação da identidade dos indivíduos e entidades envolvidos. Em matéria criminal, há que se estabelecer as identidades da vítima e do agressor, para que o processo atinja seus objetivos. O Código de Processo Penal, inclusive, determina em seu artigo $6^{\circ}$, inciso VIII, que se deve fazer no inquérito policial a "identificação do indiciado pelo processo datiloscópico, se possível".

Croce pondera que a identidade é ao mesmo tempo um dever e um direito $^{50}$. Pode-se, com efeito, reconhecer o direito de obter uma identidade civil reconhecida pelo ordenamento jurídico, bem como o direto de ter sua identidade protegida pela lei. Por outro lado, o reconhecimento dessa identidade impõe alguns deveres aos seus possuidores. E o Estado pode exigir que seus cidadãos declarem sua identidade junto aos órgãos oficiais.

Como direito, o reconhecimento da identidade é um Direito Humano Fundamental. De fato, a Declaração Universal dos Direitos Humanos aprovada pela Assembléia Geral das Nações Unidas em 10 de dezembro de 1948, em seu artigo VI, declara que "todo homem tem direito de ser, em todos os lugares, reconhecido como pessoa perante a lei”. Esse direito de ser reconhecido como pessoa só pode ser compreendido como o reconhecimento pelos governos da dignidade humana de cada indivíduo em sua manifestação única e insubstituível. Em outras palavras, só se concebe a pessoa humana como uma pessoa individual e, portanto titular de uma identidade. O conceito de dignidade humana, como se verá, implica o conceito de identidade.

\footnotetext{
${ }^{49}$ Processo estocástico é sinônimo de processo aleatório, definido em matemática como "uma família de variáveis aleatórias". Um exemplo de processo estocástico são os resultados obtidos por uma série de lançamentos de dados.

${ }^{50}$ Manual de medicina legal, p.36.
} 
Comparato conceitua a dignidade humana como o caráter comum a todos os homens, independentemente de "suas diferenças biológicas e culturais que os distinguem entre si, que os torna capazes de amar, descobrir a verdade e criar a beleza" ${ }^{51}$. Esse caráter comum passou a ser reconhecido sucessivamente pelo pensamento religioso, pelo pensamento filosófico e pelo pensamento científico. As religiões monoteístas, a começar pelo judaísmo, colocaram o homem como o mais importante fruto da criação divina, tendo sido dado a ele poder sobre todas as criaturas e toda a criação ${ }^{52}$. A importância do homem entre todas as criaturas deriva do reconhecimento de sua natureza única, que o torna "semelhante aos Deuses, versado no bem e no mal" "53. As reflexões filosóficas da civilização grega identificaram essa capacidade com a razão, o que torna o homem capaz de compreender o universo e a si mesmo. O cristianismo adiantou mais um passo nesse reconhecimento da dignidade humana ao criar o conceito de indivíduo capaz de receber a graça divina. Por fim, a própria evolução biológica e cultural do homem que é demonstrada pela ciência, aponta-o como um ser único em toda a cadeia biológica ${ }^{54}$. Ele é um ser único porque sempre está transformando suas características biológicas e culturais, de tal forma que o homem é um constante vir-a-ser, porque é moldado por seu passado e está sempre recriando sua personalidade diante das circunstâncias em que vive. Assim, o próprio conceito de dignidade humana reconhece o caráter único da identidade humana como o fator que torna todo e cada homem detentor dos Direitos Humanos Fundamentais. Nos dizeres de Comparato, "O caráter único e insubstituível de cada ser humano, portador de um valor próprio, veio demonstrar que a dignidade da pessoa existe singularmente em todo indivíduo" ${ }^{55}$.

A declaração dos Direitos da Criança, aprovada pela assembléia Geral das Nações Unidas em 20 de novembro de 1959 estabelece em seu artigo $3^{\circ}$ que "Desde o dia em que nasce, toda criança tem direito a um nome e uma nacionalidade, ou seja, ser cidadão de um país". Esse direito a um nome e nacionalidade é o reconhecimento do direito à individualização e, portanto à identidade.

A Constituição Brasileira reconhece em seu artigo $1^{\circ}$ que a dignidade da pessoa humana é um dos fundamentos da república (art. $1^{\mathrm{o}}$, III). Também estabelece no art. $5^{\circ}, \mathrm{X}$, como um dos direitos e garantias concedidos pelo Estado o respeito à intimidade, à vida privada, à imagem das pessoas e à sua honra. Essa garantia inclui, portanto

\footnotetext{
${ }^{51}$ Fábio K. COMPARATO, A afirmação histórica dos direitos humanos, p.1.

52 Gênesis 1, 26-30.

${ }^{53}$ Gênesis 3, 22.

${ }^{54}$ A afirmação histórica dos direitos humanos, p.1-30.

${ }^{55}$ Fábio K. COMPARATO, A afirmação histórica dos direitos humanos, p.29.
} 
os direitos personalíssimos, entre os quais o direito a identificação correta do cidadão. Em consonância a essas garantias, o Código Civil ${ }^{56}$ também reconhece em seu Capítulo II intitulado "Dos Direitos da Personalidade", artigos 11 a 21, o direito a um nome e o respeito à identidade pessoal e à integridade física, que nada mais é que a identidade biológica. A Lei da Execução Penal (Lei 7.210/1984), no artigo 41, inciso XI, reconhece o direito do preso receber chamamento nominal.

O respeito à identidade garante o direito de não violação dos dados pessoais e biológicos. Os dados pessoais são inclusive passíveis de consulta e retificação pelo instituto do Habeas Data, consagrado pela Constituição em seu artigo $5^{\circ}$, inciso LXXII. O sigilo dos dados pessoais biológicos é garantido pelo respeito ao sigilo profissional estabelecido no Código de Ética Médica, artigos 102 a 109 e protegido pelo crime insculpido no artigo 154 do Código Penal. Essas informações incluem o patrimônio genético de cada um, que, como foi visto acima, representa a forma mais íntima de identidade biológica. Os dados biométricos de cada indivíduo também são protegidos quanto ao seu uso indevido, pois são considerados sigilosos.

$\mathrm{O}$ artigo $5^{\circ}$, inciso LVIII, por outro lado, garante que aquele que se identificar civilmente, ou seja, por meio de documento de identidade legalmente reconhecido, tem o direito de ser dispensado da identificação criminal, salvo nas hipóteses previstas em lei. Essa necessidade de identificação criminal existe, como já visto, por força do o artigo $6^{\circ}$, inciso VIII, do Código de Processo Penal.

O dever de identificar-se ${ }^{57}$ (declarar sua identidade) não é abraçado por todos os ordenamentos, havendo aqueles que consideram a identificação compulsória uma ingerência do estado na vida privada, só justificável em situações de exceção. É essa a posição de alguns países como Austrália, Dinamarca, Irlanda, Japão, Coréia do Sul, Noruega e Estados Unidos, que fazem sérias restrições à identificação datiloscópica para fins civis, com o argumento que a identificação exata e minuciosa deve ser relegada às pessoas consideradas nocivas à sociedade, razão pela qual uma simples coleta de impressões digitais pode, nesses países, constituir sério agravo aos direitos individuais ${ }^{58}$. Esse argumento tem peso relativo em

\footnotetext{
${ }^{56}$ Capítulo II Dos Direitos da Personalidade, artigos 11 a 21.

${ }^{57}$ Como será visto a seguir, identificação é o processo de determinação da identidade de algo ou alguém. Neste ponto do texto o termo quer expressar o ato do próprio indivíduo declarar sua identidade.

${ }^{58}$ Instituto Nacional de Identificação, informação do sítio http://www.dpf.gov.br/centrais/ini/ini continuacao.htm acesso em $24 / 03 / 2007$.
} 
razão do princípio da igualdade entre as pessoas, que não admite definiç̧ões discriminatórias como a de ser "nocivo à sociedade".

A revelação da identidade é considerada no ordenamento brasileiro um dever em algumas situações, e as leis assim a prevêem. A Constituição em seu artigo $5^{\circ}$, inciso IV, determina que só é livre manifestação do pensamento se não houver anonimato. $\mathrm{Ou}$ seja, para livremente manifestar-se o autor tem o dever de identificar-se. Os que realizam interrogatórios policiais ou prisões também têm o dever de identificar-se aos que a se submetem a essas ações, no teor do artigo $5^{\circ}$, LXIV da Carta Magna. Os indiciados e interrogados por seu turno devem identificar-se civilmente, se não quiserem ser submetidos à identificação criminal, o que lhes é facultado pelo artigo 5 $5^{\mathrm{a}}$, LVIII. O mesmo artigo determina que leis regulamentarão essa identificação criminal.

A Lei 9034/1995, a chamada lei do Crime Organizado, no seu artigo $5^{\circ}$, estabelece que "a identificação criminal de pessoas envolvidas com a ação praticada por organizações criminosas será realizada independentemente da identificação civil". Também a Lei 10.054/2000 estabeleceu, em seu artigo $3^{\circ}$, que a identificação civil não impede a identificação datiloscópica nos casos de indiciados por homicídio, crimes contra o patrimônio que envolvam violência ou ameaça, receptação qualificada, crimes contra a liberdade sexual ou crime de falsificação de documento público, e quando houver suspeitas fundadas da falsificação do documento, inclusive se o documento tiver sido registrado como extraviado. Também se o documento estiver deteriorado ou tiver sido expedido há tempo suficiente para dificultar a identificação de suas características essenciais, se o indiciado tiver em seu registro policial indícios de uso anterior de outros nomes ou qualificações deverá ser criminalmente identificado pela datiloscopia e fotografia. Por outro lado, a lei admite o prazo de 48 horas para que no caso da dúvida exposta acima, o indiciado comprove sua identificação civil.

Civilmente, deve-se comprovar a identidade dos indivíduos no início e do fim da vida, no reconhecimento da filiação e na comprovação da idade e para a realização de certos negócios jurídicos. O exercício de certos direitos exige a verificação da identidade por documentos ou senhas. No entanto, a identificação por cédula de identidade é opcional $^{59}$.

\footnotetext{
${ }^{59}$ Mário Sérgio SOBRINHO, Identificação criminal, p. 63.
} 
São documentos de identidade civil: a Cédula de Identidade, expedida pelos Órgãos de Identificação, vinculados às Secretarias de Segurança Pública, na sua maioria, no quadro da Polícia Civil e da Secretaria de Segurança Pública de cada estado; a Carteira Nacional de Habilitação, expedida pelos Departamentos Estaduais de Trânsito; as diversas cédulas de identidade profissionais, emitidas por entidades reguladoras de classes como a $\mathrm{OAB}^{60}$; documentos identificadores de autoridades como as policiais, Ministério Público e etc. a Carteira de Trabalho e o passaporte. Estes documentos contêm além da fotografia, a impressão digital do polegar direito do portador como registro identificador. $\mathrm{Na}$ ocasião da expedição desses documentos o indivíduo apresenta seu registro civil, dados pessoais biográficos e fotografia recente e fornece suas impressões digitais para registro datiloscópico a ser arquivado no Órgão de Identificação do estado. Existe a nível federal o Instituto de Identificação Nacional, ligado à Polícia Federal que coordena as informações da identidade fornecidas pelos órgãos identificadores estaduais. No entanto, a disponibilidade e o intercâmbio dessas informações aos institutos participantes ainda é insuficiente, sendo possível para o mesmo indivíduo obter diversas Cédulas de Identidade em estados diferentes. A proposta de uma cédula de identificação nacional única ainda não vingou no Brasil, embora haja lei prevendo-a (Lei 9.454/1997). O temor de que a implementação de número de identidade único possa levar à ingerência indevida do Estado na vida privada tem retardado a adoção da mesma em nosso país, assim como tem sido em muitos outros ${ }^{61}$.

\footnotetext{
${ }^{60}$ Lei 6206/75.

${ }^{61}$ Luís Renato COSTA et alli. Identificação humana, Volume II. P. 106. Mário Sérgio SOBRINHO, Identificação criminal, p. $62-74$.
} 


\section{CAPÍTULO II. IDENTIFICAÇÃO}

\subsection{CONCEITO, CLASSIFICAÇÃO E REQUISITOS DE VALIDADE}

Diferencia-se a identidade da identificação. Identidade, como já visto, é um conceito, uma definição da "mesmice". ${ }^{62}$ Identificação é um processo: o processo por meio do qual se determina a identidade de algo ou alguma coisa. Alcântara a define como a prova "por meio técnico e/ou científico que aquela pessoa é ela e não outra ${ }^{63 "}$. Para Odon Ramos Maranhão, identificação é “exatamente o processo, método ou técnica, usado para evidenciar as propriedades exclusivamente individuais ${ }^{64 \%}$. Nesse mesmo diapasão, Flamínio Fávero chama a atenção para o caráter de processo ou sucessão de atos que é característico da identificação, que é por este autor considerado uma forma de diagnóstico ${ }^{65}$. Para Hélio Gomes ${ }^{66}$, "é o emprego de meios adequados para determinar a identidade ou a não identidade". Esse mesmo autor cita uma definição de Littré ${ }^{67}$, para quem a identificação é "a descrição da pessoa que se quer fazer reconhecer".

Almeida Júnior ${ }^{68}$ avança na definição ao descrever o processo de identificação do homem como a demonstração que "certo corpo humano, que em dado momento se apresenta a exame, é o mesmo que em ocasião anterior já havia se apresentado". Em outras palavras, o autor conclui que identificar é "reconhecer". Mas esse reconhecer não é um reconhecimento empírico, mas sim um reconhecimento científico ${ }^{69}$. Importa diferenciar os dois conceitos, pois o reconhecimento empírico dos indivíduos, baseado em testemunhos e memória pessoal, não tem a mesma precisão científica ou fé jurídica do processo de identificação. Dessa forma, os autores conceituam o reconhecimento como o processo identificador baseado no conhecimento anterior da pessoa $^{70}$. Fernando da Costa Tourinho ${ }^{71}$ chama a atenção para a pequena validade do reconhecimento empírico em juízo, ao dizer que “o reconhecimento é, de todas as provas, a mais falha, a mais precária. A ação do tempo, o

\footnotetext{
${ }^{62}$ Odon Ramos MARANHÃO, Curso básico de medicina legal, p. 53.

${ }^{63}$ Perícia médica judicial, p. 24.

${ }^{64}$ Curso básico de medicina legal, p. 53.

${ }^{65}$ Medicina legal, p. 62.

${ }^{66}$ Medicina legal, p. 45.

${ }^{67}$ Medicina legal, p. 45.

${ }^{68}$ Lições de medicina legal, p. 12.

${ }^{69}$ Odon Ramos MARANHÃ̃, Curso básico de medicina legal, p. 54

${ }^{70}$ Hermes R. ALCÂNTARA, Perícia medico judicial, p. 24.

${ }^{71}$ Fernando da Costa TOURINHO Fo ${ }^{\circ}$, Manual de processo penal, p.494.
} 
disfarce, as más condições de observação, os erros por semelhança, a vontade de reconhecer, tudo, absolutamente tudo, torna o reconhecimento uma prova altamente precária”.

Em comum com o reconhecimento empírico, no entanto, o processo identificador tem três fases. Existe um primeiro registro ou fichamento em que são armazenados, de forma precisa, determinados caracteres únicos e permanentes que possam assegurar, no futuro, a distinção desse indivíduo dos demais. No reconhecimento, essa fase ocorre pela fixação na memória, ou por meios não científicos, como fotos comuns, de determinadas características do indivíduo a ser reconhecido no futuro. Em outra fase, há um segundo registro, ou inspeção, em que os mesmos caracteres são examinados em um indivíduo em momento posterior. Finalmente, há um julgamento, em que mediante a comparação entre os dois registros emite-se uma opinião sobre a identidade ou não entre os dois indivíduos. O que diferencia os dois processos é presença de rigor técnico-científico em todas as fases da identificação, rigor ausente no reconhecimento leigo ${ }^{72}$.

Identificar também tem o aspecto de validar a pretensão à identidade. Ou seja, identificar pode significar a confirmação da pretensão de alguém ser determinada pessoa ${ }^{73}$. Esse processo é chamado de verificação. Exemplificativamente, se alguém se apresenta em uma agência bancária para sacar quantia depositada em determinada conta deve demonstrar ser o titular da mesma por meio de assinaturas, uso de cartões exclusivos e senhas, por vezes, até fornecendo dados pessoais de conhecimento mais íntimo do titular. Esse processo de identificação é chamado comparação "um para um" ou 1-1". Comparam-se características do indivíduo atualmente presente, com o registro de identidade de alguém que esse indivíduo afirma ser, julgando-se simplesmente se a identidade se confirma ou não.

Por outro lado, podem-se comparar os dados de alguém com os dados de todos os membros de um grupo de indivíduos registrado em momento anterior para tentar-se estabelecer uma correspondência suficientemente segura para identificar essa pessoa. É a comparação "um para muitos" ou 1-n. Este processo é a identificação propriamente dita, pois tenta definir as características da individualidade de alguém em comparação com os seus semelhantes ${ }^{75}$.

\footnotetext{
${ }^{72}$ A. ALMEIDA Jr., Lições de medicina legal, p. 12.

${ }^{73}$ Ver a definição de LITTRÉ citada acima, que vai ao encontro de identificação como verificação.

${ }^{74}$ Douglas VIGLIAZZI, Biometria: medidas de segurança, p. 4

${ }^{75}$ Ibid., p. 4.
} 
As técnicas de identificação podem ser classificadas de acordo com a natureza dos conhecimentos exigidos para sua execução, de acordo com sua utilização jurídica, de acordo com a natureza dos caracteres a serem registrados, entre outros.

Pelo critério da natureza dos conhecimentos exigidos para sua execução, as técnicas podem ser classificadas em identificação policial (ou judiciária) e identificação médico-legal. A identificação policial, nos dizeres de Hélio Gomes é realizada por policiais "não exigindo, para seu emprego, conhecimentos médicos obrigatórios" ${ }^{76}$. Para Flamínio Fávero esta identificação "visa, sobretudo, à caracterização de delinqüentes em operações rápidas" ${ }^{77}$. Já a identificação médico-legal, deve ser realizada por médicos por exigir conhecimentos especializados para sua adequada execução. Exemplificam a identificação policial a datiloscopia e a fotografia sinalética. São técnicas médico-legais a determinação científica da raça, sexo, idade, e etc.

Essa classificação tem uma base metodológica frágil, já que, técnicas baseadas em conhecimentos médicos podem ser realizadas por não médicos desde que efetivamente treinados para tanto. Além disso, outros profissionais da área médicobiológica podem realizar técnicas úteis para a identificação, como exames de DNA e estudos antropológicos.

$\mathrm{Na}$ verdade, na formulação das técnicas de identificação humana são muitas vezes necessários conhecimentos biológicos e médicos para conferir-lhes validade científica. Após esta etapa ter sido transposta, porém, é possível operacionalizar o uso dessas técnicas de tal forma que os que as aplicam não necessitem de conhecimentos médicos avançados.

As técnicas de identificação biométrica, objeto do presente estudo, são exemplos de utilização de conhecimentos da área médica em um processo identificador realizado por leigos. Uma das maiores vantagens dessas técnicas é justamente a possibilidade de realizar a identificação sem a intervenção de especialistas, seja médicos ou não médicos no processo de fichamento ou de reconhecimento posterior.

Também a associação da identificação não-médica com procedimentos policiais ou judiciais de natureza criminal é criticável. Ora, na vida civil é cada vez mais necessário validar a identidade de alguém junto a entidades de todas as naturezas,

\footnotetext{
${ }^{76}$ Medicina legal, p. 45.

${ }^{77}$ Hélio GOMES, Medicina legal, p. 63.
} 
desde escolas, empresas, até instituições bancárias. Não é somente ao Estado que interessa identificar alguém. Por isso, não só leigos policiais podem utilizar-se dessas técnicas.

É mais relevante observar que há perícias de identificação que requerem atos médicos, assim entendidos como atribuições exclusivas desses profissionais, como necropsias, exames físicos especializados e etc. Outras prescindem não tanto de conhecimentos médicos, mas sim da competência profissional médica legalmente estabelecida, ressalvando-se em seu âmbito de atuação a identificação realizada por odontólogos por meio da análise de dentes ${ }^{78}$. A identificação realizada por médicos por meio de atos médicos é denominada identificação médico-legal.

Pelo critério da utilização jurídica, podem-se classificar os métodos de identificação em identificação civil e identificação criminal ${ }^{79}$. A primeira tem por objetivo a identificação do indivíduo para que possa ser sujeito de direitos e obrigações na vida civil. A segunda reveste-se de importância na atuação do Estado na repressão das condutas ofensivas aos bens jurídicos de dignidade penal, identificando os autores ou suspeitos e as vítimas de delitos, para fins penais. Como já visto anteriormente, a identificação civil é um direito e um dever ao mesmo tempo, obstaculizando a identificação criminal em determinadas situações.

Finalmente, do ponto de vista dos caracteres a serem registrados, podem-se classificar os processos de identificação em fisiológicos ou biológicos, e psíquicocomportamentais. Os caracteres fisiológicos ou biológicos são aqueles obtidos diretamente das propriedades físicas orgânicas dos indivíduos. Já os psíquico-comportamentais não dependem diretamente das propriedades orgânicas da pessoa, mas sim, do seu comportamento ou resposta psíquica. Por exemplo, a identificação pela dinâmica do andar ou pela dinâmica da digitação em teclado é realizada por meio da observação dos comportamentos da pessoa ao caminhar ou ao trabalhar em um micro-computador. Já a identificação pela utilização de senhas ou segredos é uma identificação por caracteres psíquicos. Há sistemas intermediários,

\footnotetext{
${ }^{78}$ Para a Associação Médica Brasileira, ato médico é "todo procedimento técnico-profissional praticado por médico legalmente habilitado e dirigido para a promoção da saúde e prevenção da ocorrência de enfermidades ou profilaxia (prevenção primária); a prevenção da evolução das enfermidades ou execução de procedimentos diagnósticos ou terapêuticos (prevenção secundária); a prevenção da invalidez ou reabilitação dos enfermos (prevenção terciária)". Por essa definição, a identificação médico-legal atende a segunda parte da definição procedimentos diagnósticos.
}

${ }^{79}$ Adriano R. L. FIGINI e José Roberto L. e SILVA, Identificação Humana, p. 140. 
no entanto, como a identificação pela assinatura e a identificação pela voz, que dependem de características comportamentais e físicas ${ }^{80}$.

De outra parte, para que tenham validade científica, os métodos de identificação precisam atender a alguns requisitos. São requisitos de validade dos métodos de identificação a unicidade, a imutabilidade (perenidade), a variabilidade (classificabilidade) e a praticabilidade ${ }^{81}$. Alguns desses requisitos referem-se à característica base do processo identificador, outras ao processo em si mesmo. Assim, a unicidade, a imutabilidade e a variabilidade são atributos da característica utilizada e a classificabilidade e a praticabilidade são qualidades do método identificador.

A unicidade é a propriedade de cada característica ou de um conjunto de características serem únicas. Ao pretender identificar um indivíduo, admite-se que este ser é único em relação aos seus semelhantes, se não em um caractere isolado, pelo menos em um conjunto dado de caracteres. O método científico de identificação, por essa razão, deve utilizar e ser capaz de reconhecer um conjunto de dados único daquele indivíduo, irrepetível nos demais da mesma espécie ${ }^{82}$.

A imutabilidade é o atributo daquilo que não se modifica enquanto existe. Evidentemente é atributo relativo porque tudo o que existe modifica-se com a passagem do tempo. Mas, se comparado com outro objeto ou ser, algo pode não sofrer mudanças importantes ao longo do tempo. Perenidade, que alguns consideram sinônimo de imutabilidade, na verdade não o é. Perene é aquilo que existe sempre, não estando essa qualidade relacionada a modificações com a passagem do tempo, mas sim com a existência infinita do objeto ou ser.

De qualquer forma, o método de identificação ideal utiliza características que não sofrem mudanças significativas ao longo do tempo para que o segundo registro do processo identificador (ver acima) possa ser realizado de forma confiável ${ }^{83}$. Além disso, idealmente, o caractere observado deve existir pelo mais longo tempo possível, para permitir sua utilização indefinidamente ${ }^{84}$.

\footnotetext{
${ }^{80}$ Douglas VIGLIAZZI, Biometria: medidas de segurança, p. 12.

${ }^{81}$ A. ALMEIDA Jr., Lições de medicina legal, p. 13-15, Odon Ramos MARANHÃO, Curso básico de medicina legal, p. 55-57, Eduardo R. A. DEL-CAMPO, Medicina legal, p. 61-62.

${ }^{82}$ Odon Ramos MARANHÃO, Curso básico de medicina legal, p.55.

${ }^{83}$ Ibid., p.55.

${ }^{84}$ Eduardo R. A. DEL-CAMPO, Medicina legal, p. 61
} 
A variabilidade permite o reconhecimento de uma dada característica em diferentes indivíduos. Assim, uma característica que varia pouco não serve para identificação. Um exemplo seria o "branco dos olhos". Além disso, a variabilidade facilita a classificação dos indivíduos. Isso porque justamente as diferentes formas do caractere permitem a disposição dos indivíduos em grupos classificáveis ${ }^{85}$. Essa classificação é o que viabiliza a recuperação dos dados individuais na segunda fase do processo de identificação. Com o avanço das técnicas informáticas a etapa da classificabilidade, entendida como possibilidade de arquivamento e localização de indivíduos, tornou-se mais acessível e rápida.

A praticabilidade é o requisito segundo o qual o método de identificação deve ser prático, para que suas três fases sejam cumpridas com eficiência ${ }^{86}$. Também este requisito é relativo. Um método de identificação pode ser viável para uma finalidade e não para outra. Assim, a identificação pela "DNA fingerprint" é excelente para a identificação do pai de um indivíduo, mas impraticável para a validação da identidade de um usuário de um sítio restrito da Internet. $\mathrm{O}$ avanço tecnológico também pode modificar esse requisito, por exemplo, em um passado recente, as técnicas de identificação pela biometria eram impraticáveis pela sua complexidade, o que se tornou diferente com o avanço da tecnologia da informação e da captação de imagens.

Ao longo da história diversos métodos de identificação foram utilizados. A partir do século XIX, os métodos passaram a ter bases científicas, e tornaram-se progressivamente mais eficientes. Serão a seguir descritos alguns destes métodos dividindo-os em identificação médico-legal e judicial, apesar da já referida impropriedade da última denominação.

\footnotetext{
${ }^{85}$ A. ALMEIDA Jr., Lições de medicina legal, p. 14.

${ }^{86}$ Ibid., p. 14.
} 


\subsection{IDENTIFICAÇÃO MÉDICO-LEGAL}

Como acima referido, a identificação médico-legal é a que depende da competência atribuída legalmente aos médicos na realização de atos médicos de identificação. Flaminio Fávero a divide em três partes: a física, a funcional e a psíquica. A física refere-se à parte biológica orgânica propriamente dita. É a determinação de parâmetros biotipológicos de relevo, como por exemplo, a identificação da espécie animal da amostra, do sexo, da idade, e etc., realizada na espécie humana principalmente por meios antropológicos. A funcional refere-se aos movimentos e às funções orgânicas do indivíduo, como seu modo de andar, de escrever, sua voz, sua identidade social e sua forma de apresentar-se na sociedade. E por fim, a identidade psíquica estuda as características e sinais individualizadores de cada pessoa por meio de conhecimentos psiquiátricos ou psicológicos ${ }^{87}$. Atualmente, a avaliação funcional é objeto de algumas técnicas de biometria, como a avaliação do modo de andar, ou de digitar em teclados de computador, o que a aproxima da identificação judiciária ${ }^{88}$.

São métodos de identificação médico-legal as técnicas baseadas em antropologia forense, identificação por marcadores sangüíneos e de histo-compatibilidade, a identificação pelo DNA, e a identificação odonto-legal.

\subsubsection{Identificação antropológica}

Denomina-se identificação antropológica a utilização dos conhecimentos da antropologia médica para estabelecer a identidade de restos humanos ou determinar algumas características de interesse jurídico em organismo vivo ou morto, especialmente quando métodos mais imediatos de identificação não podem ser realizados ${ }^{89}$. Os ossos são a principal estrutura orgânica analisada em perícias antropológicas médicolegais, embora outros tecidos sejam também analisados, como pelos e dentes.

As questões periciais em que mais freqüentemente se utilizam conhecimentos de antropologia forense são relacionadas aos citados aspectos biotipológicos, como a determinação da espécie que originou o fragmento orgânico estudado, a idade do indivíduo, à sua raça, ao sexo do doador da amostra, sua estatura e a presença de possíveis

\footnotetext{
${ }^{87}$ Flamínio FÁVERO, Medicina legal, p. 63, 123 e 130.

${ }^{88}$ Douglas VIGLIAZZI, Biometria: medidas de segurança, p. 11-12.

${ }^{89}$ Luiz Fernando JOBIM et. al., Identificação humana vol. II, p. 109.
} 
sinais congênitos ou adquiridos. De acordo com a amostra orgânica residual tais questões podem ser respondidas por diferentes técnicas. Por exemplo, em corpos carbonizados, pode-se tentar localizar os órgãos sexuais internos do cadáver para determinar seu sexo, o que é evidentemente impossível de se realizar em ossadas. Em corpos em estado de decomposição, por vezes, é possível estimar-se a idade provável pelo aspecto macroscópico.

A determinação da espécie impõe-se na análise de fragmentos orgânicos isolados que não têm procedência humana comprovada. Estes fragmentos podem ser pelos, unhas, dentes, sangue, saliva, secreções, restos teciduais, ossos isolados ou ossadas e outros. ${ }^{90}$. O aspecto morfológico é o primeiro elemento de análise na diferenciação do material humano do não-humano, o que é de relevo para os ossos e para os anexos cutâneos. Já para a identificação do sangue humano existe uma série de reações imunológicas e químicas específicas $^{91}$. Também é possível identificar restos humanos pelas características próprias dos ossos, dos pelos e dos dentes ${ }^{92}$.

A perícia antropológica da idade é relativamente imprecisa pelos métodos atualmente em uso. Alguns fatores contribuem para essa imprecisão. Por exemplo, o ritmo de envelhecimento não é uniforme para todos os indivíduos e etnias. Além disso, os padrões atuais de identificação são médias estatísticas, e por isso, aplicáveis com restrições a cada caso particular. A estimativa da idade tem importância jurídica não só para auxiliar na identificação de um indivíduo, mas também para finalidades civis e criminais. Por exemplo, é importante saber se um indivíduo atingiu a idade biológica de 18 anos e assim adquiriu a capacidade civil para validar certos atos jurídicos, ou se um indivíduo vítima de um delito tem mais de 60 anos porque esta é uma circunstância agravante para a pena ${ }^{93}$.

A determinação da raça é procedimento auxiliar na identificação médico legal. Isto porque o conceito de raça vem sofrendo progressivo descrédito após as pesquisas genéticas terem demonstrado as similaridades ao nível do DNA entre grupos

\footnotetext{
${ }^{90}$ Luiz Fernando JOBIM et. al., Identificação humana vol. II, p. 120.

${ }^{91}$ Algumas delas são: a anafilaxia, o desvio do complemento, soros precipitantes, eletroforese, hemaglutinação passiva, método citológico e o método enzimático. Odon Ramos MARANHÃO, Curso básico de medicina legal, p. 116.

${ }_{92}$.Hermes Rodrigues ALCÂNTARA, Perícia médica judicial, p. 24; A. ALMEIDA Jr., Lições de medicina legal, p. 104; Flamínio FÁVERO, Medicina legal, p. 68-70.

${ }^{93}$ Do ponto de vista jurídico, as idades mais importantes são 12 anos (início da adolescência para o Estatuto da Criança e do Adolescente, art $2^{\circ}$ ), 14 anos (idade de presunção de inocência para o Código Penal ver art. $121 \S$ $4^{\circ}, 126$ parágrafo único e etc.), 16 anos, (início da capacidade civil relativa art. $4^{\circ}$ do Código Civil), 18 anos, (maioridade civil e penal art. $5^{\circ}$ do Código Civil e 27 do Código Penal), 21 anos (menoridade penal como circunstância atenuante, Código Penal art. 65 e 115), 60 anos (idade de início da velhice para o Estatuto do Idoso L. 10.741/2003 art. $1^{\circ}$ e idade em que o regime de separação de bens no casamento é obrigatório art. 1641 II do Código Civil).
} 
étnicos e raciais antes considerados completamente distintos ${ }^{94}$. Pode-se, no entanto, a partir de determinada amostra biológica, procurar-se identificar o fenótipo cor da pele. Em países de população tão miscigenada como o Brasil essa identificação é difícil. Preliminarmente, se o estado do indivíduo permitir, o aspecto dos cabelos, face, mãos e etc. possibilitam a identificação do fenótipo com facilidade. Se a amostra for óssea, o estudo do crânio é o mais adequado para essa identificação, devendo utilizar-se diversos índices para aumentar a precisão da perícia ${ }^{95}$.

A perícia médico-legal do sexo nem sempre é fácil. Isso porque muitas vezes o único material para a perícia é uma ossada ou um osso isolado. Além disso, existem estados intersexuados que apresentam características mistas dos dois sexos. Para indivíduos vivos, em geral, o exame físico é suficiente para identificação médico-legal do sexo. Se houver dúvida, pode ser preciso solicitar um exame de cariótipo ${ }^{96}$, que estudará o sexo genético do indivíduo. Os testes de DNA são também importantes nessa pesquisa. É possível também determinar o sexo em ossadas com certa precisão porque quase todos os ossos apresentam dimorfismo sexual. Os resultados mais confiáveis são obtidos por meio do estudo dos ossos do crânio, da pelve, o fềmur, o rádio, a clavícula, o calcâneo e a primeira vértebra cervical ${ }^{97}$.

Sinais particulares congênitos e adquiridos, estes em razão de doenças, de fatores ambientais ou da atividade profissional, podem ser detectados em ossos ou restos orgânicos auxiliando sua identificação. São exemplos de sinais congênitos as alterações dos dedos da mão, como sindactilia (união de dois dedos) ou dedos extranumerários. Como doenças hereditárias podem-se citar o estrabismo, as patologias cardíacas e as da face (lábio leporino, por exemplo). As fraturas, a perda de membros, as cirurgias sofridas e as doenças profissionais, como a silicose e o saturnismo ${ }^{98}$, são exemplos de alterações adquiridas que podem ser detectadas em ossadas e restos humanos para identificá-los.

\footnotetext{
${ }^{94}$ Michael J. BAMSHAD e Steve E. OLSEN, Ambigüidades que limitam uma definição de raça, in http:// www2.uol.com.br/sciam/conteudo/materia/matéria_38html acesso em 23 de abril de 2004.

${ }^{95}$ Luiz Fernando JOBIM et. al., Identificação humana vol. II p.135 e 136. Alguns desses índices são: o índice facial superior, o índice nasal, medida do prognatismo, e o índice cefálico horizontal.

${ }^{96}$ Cariótipo é o conjunto dos cromossomos de um indivíduo. O exame do cariótipo pode ser realizado pelo estudo das células com a maior taxa de multiplicação do organismo, como as células da série sangüínea.

${ }^{97}$ Luiz Fernando JOBIM et. al., Identificação humana vol. II p. p. 128-133.

${ }^{98}$ Silicose é doença profissional adquirida pelos trabalhadores que manipulam a sílica seja em forma de minério, seja em forma de compostos da indústria do vidro. Saturnismo é a intoxicação pelo minério chumbo. Odon Ramos Maranhão, Curso básico de medicina legal, p.477, 479.
} 
A história da identificação antropológica confunde-se, nos seus primórdios, com a Criminologia positivista. Esta relação será brevemente discutida a seguir.

\subsubsection{Identificação antropológica e a identificação do homem delinqüente}

A evolução da Criminologia como disciplina científica apresenta, segundo alguns autores, uma fase pré-científica ${ }^{99}$. Durante esse período, alguns estudiosos substituíram métodos abstratos especulativos por métodos analíticos baseados na observação de fatos particulares que, por indução, levariam a conclusões gerais. Essas práticas não visavam à compreensão específica do fenômeno criminoso, mas ao estudo do que hoje chamaríamos a psique do indivíduo. De todo modo, o criminoso enquanto homem "anormal", segundo a visão da época, era uma das personalidades doentias a serem estudadas e caracterizadas. Inicia-se nesses tempos a pesquisa de características físicas que poderiam identificar alguém como um "criminoso nato", em outras palavras, alguém que por disposições orgânicas estaria propenso a cometer crimes. Este processo identificador do criminoso por suas características físicas é também precursor dos processos de identificação médico-legal e judiciária, especialmente daqueles que utilizam conhecimentos de antropologia médica. A seguir, serão vistos de forma breve, alguns dados históricos dessa evolução da Criminologia e dos métodos de identificação antropológica.

Os estudos realizados por estes pioneiros da Criminologia, a partir do século XVI, eram pré-científicos por estarem fundamentados em observações empíricas não controladas que serviam para generalizações indevidas. Os autores conhecidos como Fisionomistas consideravam a aparência externa do indivíduo como indicadora de seu caráter, fiando-se na inter-relação entre o somático e o psíquico. Faziam-se avaliações de condenados em vida ou após sua morte para julgar se os mesmos apresentavam sinais de "maldade natural", conforme definido por um desses autores, Lavater ${ }^{100}$. O exame do rosto e corpo do criminoso servia como uma análise de um retrato mágico de sua vida ${ }^{101}$.

A Frenologia representa uma evolução das idéias dos fisionomistas, e procura situar nas diversas regiões cerebrais a sede das emoções e instintos

\footnotetext{
${ }^{99}$ Antônio García-Pablos de MOLINA e Luís Flávio GOMES Criminologia, p. 175; Sérgio S. SHECAIRA, Criminologia, p. 73-77.

${ }^{100}$ Os principais autores fisionomistas que se ocuparam do crime e criminosos são Dell Porta (italiano 153516161) e Lavater (francês 1741-1801). Na prática houve o "Édito de Valério" que instituía que entre dois possíveis culpados o mais feio deveria ser condenado. Antônio García-Pablos de MOLINA e Luís Flávio GOMES Criminologia, p. 178; Sérgio S. SHECAIRA, Criminologia, p. 78 e 79.

${ }^{101} \mathrm{Na}$ novela The Picture of Dorian Gray do autor irlandês Oscar Wilde, a personagem principal goza da juventude eterna enquanto todos os seus vícios e crimes ficam registrados em um quadro mágico que o retrata.
} 
humanos. Degenerações ou atrofias dessas regiões cerebrais poderiam ser diagnosticadas pela análise do crânio dos indivíduos utilizando-se a técnica da cranioscopia. Assim, é possível identificar o criminoso como um indivíduo que apresenta degenerações crânio-cerebrais que o associam a indivíduos primitivos ou não evoluídos. Haveria, segundo o autor espanhol Cubí Y Soler o "criminoso nato" nascido com as características orgânicas que determinariam seu futuro delinqüente. Tais concepções foram criticadas já por autores contemporâneos de seus formuladores por serem baseadas em empirismos primários ${ }^{102}$.

Os estudos craniológicos para identificarem-se criminosos ganharam um novo impulso com o desenvolvimento da antropologia no século XIX, muito influenciada pelas idéias de Charles Darwin sobre a evolução das espécies e de Spencer, sobre a evolução das sociedades humanas. $\mathrm{O}$ autor paradigmático dessa tendência é Cesare Lombroso, que com sua obra L'uomo delinqüente de 1876 tornou-se para alguns o pai da Criminologia científica. Lombroso analisou o crânio de criminosos vivos e mortos para identificar as alterações anatômicas que revelariam o absoluto determinismo desses indivíduos para tornarem-se delinquentes, já que estes seriam como elos perdidos da evolução entre os antepassados dos seres humanos e o homem moderno. Adotou também a idéia do criminoso nato. $\mathrm{O}$ criminoso teria um atavismo orgânico do homem primitivo que o impediria de internalizar as regras sociais ${ }^{103}$.

A íntima relação entre a Criminologia e a Antropologia aproximou a primeira também da Antropometria. Esta, entendida como a técnica de avaliar as dimensões ósseas e corporais teve como um de seus precursores Bertillon, criador de um dos primeiros métodos científicos de identificação humana.

A antropometria de Bertillon surgiu como método em 1878 (contemporânea, portanto, da obra de Lombroso) e serviu como suporte de identificação dos criminosos natos reconhecidos pelas idéias de Lombroso e seus seguidores. Em sua essência, porém, a técnica de identificação de Bertillon não pretendia explicar o fato criminoso nem o delinqüente como um homem doente ou degenerado. Resta apenas a ligação histórica entre uma das correntes Criminológicas e esse método de identificação precursor dos atuais, inclusive da Biometria moderna que será estudada à frente ${ }^{104}$.

\footnotetext{
102 Antônio García-Pablos de MOLINA e Luís Flávio GOMES Criminologia, p. 179 e 180; Sérgio S. SHECAIRA, Criminologia, p. 80 e 81

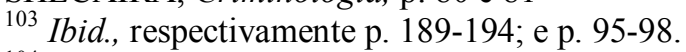

${ }^{104}$ Antônio García-Pablos de MOLINA e Luís Flávio GOMES Criminologia, p.219.
} 
O posterior desenvolvimento da Criminologia como disciplina científica levou à rejeição desses conceitos iniciais que não apresentavam qualquer conteúdo verdadeiramente científico. A identificação médico-legal, por sua vez, cada vez mais desconfirma supostas marcas orgânicas de comportamento criminoso ou de grupos de indivíduos naturalmente delinqüentes, sendo apenas um instrumento utilizado na individualização da pessoa.

A vertente sociológica da Criminologia trouxe alguns aportes para uma reflexão mais ampla da identificação médico-legal. A teoria do Label Approach considera o papel criminogênico da identificação e reconhecimento de alguém como um criminoso. Essa identificação é realizada pelas instâncias oficiais do sistema de controle social, ou seja, a polícia e o sistema penal. Ao ser "rotulado" como delinqüente o indivíduo passa a desempenhar esse papel na sociedade, seja por exclusão, seja pela identificação com outros indivíduos com quem passa a conviver nos presídios e guetos sociais. Além dos mecanismos de individuação e identificação psicológica que o título de criminoso desencadeia em seus destinatários ${ }^{105}$. É o já citado processo de estigmatização descrito acima. Essas considerações devem estar presentes aos que operam a identificação médico-legal ou judiciária em área penal, para que o exercício técnico sirva o menos possível a esses mecanismos de exclusão e aplicação de estigmas.

\subsubsection{Identificação por marcadores sangüíneos e de histocompatibilidade}

A descoberta dos tipos sangüíneos por LANDSTEINER em 1900 permitiu não só a utilização da transfusão sangüínea como tratamento de diversas doenças como também abriu a possibilidade de se identificar alguém a partir de restos de sangue ou de algumas secreções orgânicas. Isso se tornou possível pela descoberta de substâncias situadas na membrana das hemácias e de algumas outras células que permitem a classificação dos indivíduos pelo tipo de sangue que apresentam. Comparando-se assim, o tipo de sangue ou de outras substâncias orgânicas encontradas em uma amostra com o sangue de um suspeito poder-se-ia descartar ou não esse indivíduo como o doador da amostra. A hereditariedade da transmissão desses tipos, descoberta em 1930, aumentou a utilidade dessa informação por permitir a realização de testes de paternidade mais precisos dos que até então havia. Há outros sistemas de tipagem de hemácias que também podem ser utilizados aumentando a precisão, como o sistema Rh, Mn e etc. Atualmente, no entanto, métodos mais precisos substituíram o

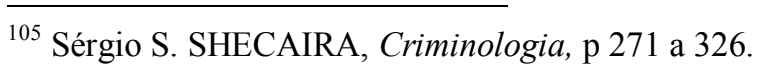


sistema $\mathrm{ABO}$ para a maioria das finalidades, servindo este como exame primário de exclusão dos suspeitos ${ }^{106}$.

O sistema de histocompatibilidade foi descoberto na década de 50 do século passado em pesquisas de transplantes em animais de laboratório. Descobriu-se então que o receptor de tecidos transplantados poderia rejeitá-los se as células de defesa reconhecessem as células transplantadas como originadas de outro organismo por meio das proteínas da membrana celular destas células. Essas proteínas foram denominadas HLA (Human Leukocyte Antigen). As proteínas são específicas de cada indivíduo por serem codificadas por genes com grande variabilidade (polimorfismo) localizados no cromossomo 6. O estudo dessas proteínas é importante para a compreensão de muitas doenças imunológicas, endócrinas, reumáticas e infecciosas. Além disso, pode ser utilizado como fator de identificação de doadores de secreções e de paternidade com certa precisão só superada atualmente pelos estudos do $\mathrm{DNA}^{107}$.

\subsubsection{Identificação pelo DNA}

O DNA é a porção codificadora dos genes, corpúsculos presentes no núcleo das células que são responsáveis pelo comando de toda a atividade celular e da transmissão dos caracteres hereditários ${ }^{108}$. Cada pessoa recebe genes de seu pai e de sua mãe, sendo que a combinação desses genes irá determinar a característica física final, ou fenótipo do indivíduo. Os diferentes fenótipos são determinados pela combinação de genes diferentes para a mesma característica. Cada um destes diferentes genes é denominado alelo. A base para a utilização dos testes de DNA na identificação humana encontra-se na diversidade dos diferentes alelos, que permite tanto identificar um indivíduo específico como relacioná-lo aos seus pais ${ }^{109}$.

A identidade biológica mais autêntica é a estrutura gênica de cada indivíduo, em outras palavras, é a estrutura molecular de seu DNA. Os milhares de genes humanos combinam-se em cada indivíduo de maneira aleatória tornando cada ser humano somente igual a si mesmo. Somente por exceção a estrutura gênica de dois indivíduos é idêntica (gêmeos univitelinos). A regra é que cada organismo apresente uma configuração molecular única em seu material hereditário genético.

\footnotetext{
${ }^{106}$ Hermes R. ALCÂNTARA, Perícia medico judicial, p. 154-155.

${ }^{107}$ Eduardo R.A. DEL-CAMPO, Medicina legal, p. 229-231.

${ }^{108}$ Norma BONACCORSO, Análise Forense de DNA disponível em http://www.peritocriminal.com.br/dnaforense.htm acesso em 28/04/2007.

${ }^{109}$ Luiz Fernando JOBIM et. al., Identificação humana vol. II, p. 8
} 
O material genético é formado por partes que codificam caracteres orgânicos e por partes que têm função estrutural e de regulação da própria estrutura do gene. Entre estas últimas encontram-se seqüências repetidas de bases conhecidas como VNTR (Variable Number of Tandem Repeat) ou mini-satélites, que contêm repetições de 9 a 80 pb, STR (Short tandem repeats) ou micro-satélites, que são constituídos de 2 a 5 pb e cadeias ainda menores conhecidas como SNPs (Single nucleotide polymorphism). Essas seqüências apresentam grande polimorfismo, isto é, há diversos tipos de seqüências nos diversos indivíduos.

O estudo dessas seqüências genéticas permite a identificação do indivíduo justamente por não codificarem nenhuma característica comum a todos os seres da mesma espécie, o que ocorreria se fossem utilizados genes que codificam, por exemplo, a insulina ou a hemoglobina. Outra vantagem do estudo dessas porções do DNA é que há muitos tipos de seqüências para cada gene, o polimorfismo, o que amplia as possibilidades de individualização de cada cadeia de DNA.

\subsubsection{Identificação pelos dentes}

A identificação pelos dentes é realizada pelos odontólogos legais sendo de competência exclusiva dos mesmos segundo a Lei 5081/66 (artigo $6^{\circ}$ ). O Conselho Federal de Odontologia reconheceu, por meio da resolução CFO-185 de 26 de abril de 1993, a odontologia legal como especialidade odontológica, cabendo a ela, entre outras atribuições a identificação humana (art. 55 a da CFO-185) ${ }^{110}$. Não é, portanto, a rigor, uma identificação médico-legal que o odontólogo legal realiza, mas a esta se compara em seu âmbito de ação e no rigor científico. Cabe aqui assinalar apenas as inúmeras possibilidades que o estudo das arcadas dentárias, do palato e dos dentes individualmente fornece para a identificação humana. É possível identificar a origem humana de dentes, a idade do indivíduo, o sexo, e por meio de registros profissionais das arcadas identificar-se o indivíduo a que pertenciam ${ }^{111}$.

\footnotetext{
${ }^{110}$ Luiz Fernando JOBIM et. al., Identificação humana vol. II p. 213 e 214.

${ }^{111}$ Hermes R. ALCÂNTARA, Perícia médica judicial, p. 40 e 226; Delton CROCE e Delton CROCE Jr., Manual de medicina legal, p. 65 e 66; Luiz Fernando JOBIM et. al., Identificação humana vol. II, p. 222- 230.
} 


\subsection{IDENTIFICAÇÃO JUDICIÁRIA}

A identificação judiciária é a realizada por leigos e por isso independente de atos médicos. Os técnicos judiciários podem realizá-las após treinamento específico. Constitui-se de métodos e processos técnicos que se baseiam essencialmente nas características físicas do indivíduo, o que torna essa identificação uma forma de reconhecimento técnico-objetivo ${ }^{112}$. Para que tenham validade e constituam meio de prova forense, os métodos de identificação judiciária devem atender os já citados requisitos de todo método de identificação científica, a saber: a unicidade, a imutabilidade (perenidade), a variabilidade (classificabilidade) e a praticabilidade ${ }^{113}$.

Os autores costumam citar os métodos que historicamente foram utilizados na identificação dos indivíduos como exemplos de identificação judiciária, já que não eram métodos médico-legais.

$\mathrm{Na}$ Antigüidade os métodos de identificação confundiam-se com a punição, sendo que serviam basicamente para identificar, reconhecer e punir criminosos ${ }^{114}$. $\mathrm{O}$ ferrete, por exemplo, consistia na imposição de uma queimadura característica em alguma parte do corpo, como o ombro ou a fronte para identificar o criminoso e o crime cometido ${ }^{115}$. Esse método foi utilizado na Grécia antiga, em Portugal e também no Brasil Império para marcar escravos fugitivos ${ }^{116}$. Também mutilações foram realizadas como forma de punição/identificação desde a Antigüidade até a Idade Média e Brasil colônia ${ }^{117}$. Nas colônias inglesas da América do Norte, os infratores eram forçados a utilizar letras em suas vestes para identificar a falta praticada $^{118}$.

Como forma de marcação corporal não exclusiva de infratores Bentham idealizou seu método dermográfico, que consistia na tatuagem de todas as pessoas desde o nascimento. Icard preconizou a marcação dos indivíduos por meio de injeções de parafina que não desapareceriam e não poderiam ser retiradas sem deixar marcas ${ }^{119}$.

\footnotetext{
112 Adriano R. L. FIGINI e José Roberto L. e SILVA, Identificação humana, p. 141.

113 Odon Ramos MARANHÃO, Curso básico de medicina legal, p. 55.

${ }^{114}$ Eduardo R.A. DEL-CAMPO, Medicina Legal, p. 58.

115 Adriano R. L. FIGINI e José Roberto L. e SILVA, Identificação humana, p. 141.

${ }_{116}^{116}$ A. ALMEIDA Jr., Lições de medicina legal, p. 15.

${ }^{117}$ Ibid., p. 16.

${ }^{118}$ No livro A letra escarlate de Nathanael Hawthorn, a personagem principal Hester Prynne é obrigada a usar uma letra escarlate "A" em sua roupa indicativa de seu pecado, o adultério.

${ }^{119}$ Delton CROCE, Delton CROCE Jr., Manual de medicina legal, p. 78.
} 
É significativo que os métodos de assinalamento por meio de roupas e de tatuagens tenham sido utilizados pelos nazistas em suas práticas criminosas contra os judeus no século passado. Tais métodos não apresentam por evidência qualquer pretensão científica ou critério de validade aceitável para uma análise técnica rigorosa ${ }^{120}$.

O assinalamento sucinto ou sumário consiste na descrição das características físicas pretensamente mais evidentes e imutáveis para a identificação do indivíduo. Desde sempre usada, desde a Antigüidade até nossos dias, serve como ponto de partida para a identificação judiciária. Dados como o sexo, a cor da pele, cabelos, altura, idade, cor dos olhos são elencados e registrados no primeiro registro de identificação para posterior verificação e julgamento de identificação. Este método apresenta praticidade e variabilidade, mas não atende aos demais requisitos científicos da identificação. No entanto, continua a ser amplamente usado ${ }^{121}$.

A fotografia, especialmente a sinalética, que procura padronizar a exposição para posterior identificação do indivíduo também é muito utilizada por sua praticidade, mas não atende os requisitos da unicidade (há muitos sósias) e da imutabilidade, já que intencionalmente os indivíduos modificam sua aparência, além da possibilidade de alterações da imagem fotográfica obtida ${ }^{122}$. Também se utiliza o retrato falado, técnica que procura tornar objetiva a descrição de alguém por meio de um desenho realizado por técnico a partir dos dados descritos por testemunhas visuais. Cabem aqui as mesmas críticas já feitas ao reconhecimento leigo, em que pese a semelhança de certos retratos falados com os indivíduos $\operatorname{descritos}^{123}$.

Outros métodos foram propostos para identificar os indivíduos, alguns baseados nas medidas de características físicas. Podem-se citar os métodos de Mathew e Anfosso, em que se mediam diâmetros cranianos (o de Anfosso utiliza também a medida do ângulo entre os dedos polegar e indicador direitos) e o de Levinsohn, que media os ossos do carpo e metatarso. Outros foram propostos baseados em características morfológicas de estruturas como o umbigo, na onfalografia de Bert e Vianay, o pavilhão auditivo, na identificação otométrica de Frigério, o padrão vascular das veias da mão, no processo flebográfico de Tamássia, e nos vasos da fronte, no sistema flebográfico de Ameuille. Todos

\footnotetext{
${ }^{120}$ Odon Ramos MARANHÃO, Curso básico de medicina legal, p. 57.

${ }^{121}$ Adriano R. L. FIGINI et al. Identificação humana, p. 142.

${ }^{122}$ Hélio GOMES, Medicina legal, p. 60.

${ }^{123}$ Fernando da Costa TOURINHO Fo ${ }^{\mathrm{o}}$, Manual de processo penal, p.494.
} 
esses métodos caíram em desuso por sua dificuldade de execução ou pela ausência dos critérios científicos na sua aplicação ${ }^{124}$.

De maior interesse são os métodos que procuraram identificar o indivíduo por características oculares, que são precursores dos métodos biométricos a serem estudados a seguir. O processo oftalmométrico de Capdeville preconizava a identificação pelas medidas da curvatura das córneas, da distância pupilar, da distância interorbitária máxima e do assinalamento de particularidades oculares como a cor da íris. Já o sistema oftalmoscópico de Levinsohn, identificava os indivíduos pelo padrão vascular dos vasos retinianos $^{125}$. Esses métodos não se tornaram universais pelas dificuldades técnicas de execução e classificação envolvidas quando de sua proposição. No entanto, de certa forma, a biometria ocular moderna utiliza os mesmos métodos hoje possíveis pelas novas técnicas existentes.

Alguns antigos métodos judiciais foram precursores do método de identificação judicial mais utilizado, a datiloscopia. Pode-se citar entre outros a poroscopia de Locard, que se baseava na imutabilidade dos poros da pele e o sistema palmar de Stockes e Wilo que utilizava os sulcos da palma da mão para identificação.

O sistema antropométrico de Bertillon é considerado o mais importante método precursor da moderna identificação judicial, base dos métodos atuais ${ }^{126}$. O sistema de Bertillon buscava atender aos critérios científicos de validade dos processos de identificação e baseava-se na associação de diversos métodos para aumentar a precisão do resultado final. Foi apresentado em 1878, sendo utilizado em Paris a partir de 1882 e finalmente adotado oficialmente em $1893^{127}$.

O sistema de Bertillon era constituído por três tipos de procedimentos: a avaliação antropométrica, o assinalamento descritivo e o assinalamento das particularidades. A avaliação antropométrica consistia na execução de medidas de diversas partes do corpo cujas dimensões eram consideradas invariáveis após a fixação da ossatura na fase adulta. Além deste motivo, esse procedimento justificava-se pela grande variabilidade dessas medidas, pela facilidade de sua obtenção e por sua classificabilidade.

\footnotetext{
${ }^{124}$ Eduardo R.A. DEL-CAMPO, Medicina legal, p. 58.

${ }^{125}$ Ibid., p. 58.

${ }^{126}$ Adriano R. L. FIGINI et al. Identificação humana, p. 144.

${ }^{127}$ Flamínio FÁVERO, Medicina legal, p. 141.
} 
As medidas utilizadas eram os diâmetros longitudinal e transversal do crânio, o diâmetro bizigomático, o tamanho dos dedos mínimo e médio, o do antebraço e do pé esquerdos, a altura da orelha direita, a estatura, a envergadura e a altura do busto, todas medidas expressas em milímetros ${ }^{128}$.

O assinalamento descritivo e o das particularidades como os sinais profissionais e individuais, tatuagens, deformidades, malformações e cicatrizes, e as características da face, eram anotados em palavras simples e convencionais, o que permitia pelo conjunto das expressões descritivas a obtenção de um verdadeiro retrato falado do indivíduo. Agregava-se a estes dados a fotografia sinalética de frente e perfil com redução constante de $1 / 7$ do original.

Ao final, esses dados eram dispostos de forma ordenada e regular a fim de permitir o arquivamento dos dados e sua recuperação para a realização do processo identificador $^{129}$.

$\mathrm{Na}$ operacionalização desse método, porém, as dificuldades surgiram $^{130}$. Ao contrário do que previa Bertillon, havia grande dificuldade na obtenção das medidas, além de apresentarem baixa reprodutibilidade, pois os resultados variavam excessivamente em diferentes ocasiões. Bertillon reconheceu essas dificuldades e na tentativa de contornar o problema adotou escalas de tolerância para a validação da comparação entre medidas. No entanto, isso não aumentou a eficiência do processo.

Tais dificuldades, porém, tornaram-se menos aceitáveis quando uma nova técnica de identificação judiciária surgiu: a datiloscopia. Essa técnica superou o sistema antropométrico de Bertillon por apresentar inúmeras vantagens em relação ao método francês ${ }^{131}$. Em todo o mundo a Bertillonagem foi substituída pela datiloscopia ${ }^{132}$, técnica realmente superior.

\footnotetext{
${ }^{128}$ Delton CROCE, Delton CROCE Jr., Manual de medicina legal, p. 79; Flamínio FÁVERO, Medicina legal, p. 141.

${ }^{129}$ Adriano R. L. FIGINI et al. Identificação humana, p. 146. A classificação se fazia dividindo-se as medidas antropométricas em três grupos, grande, médio e pequeno, classificando os indivíduos sucessivamente em cada grupo. A combinação de todas as características levava a criação de 10.206 grupos diferentes! Flamínio FÁVERO, Medicina legal, p. 141.

${ }^{130}$ Flamínio FÁVERO elenca quatro desvantagens do método: a técnica não prova a identidade apenas a exclui, as medidas dependem de fator pessoal, é processo que exige tempo e por fim, requer técnicos experimentados. Medicina legal, p. 141-142.

${ }^{131}$ O próprio Bertillon reconheceu a importância da datiloscopia para a identificação humana ao acrescentar uma impressão digital de um dos dedos da mão entre os dados de seu método de identificação.

${ }^{132}$ No Brasil a L. 902 de 29.12.1902 determinou a substituição da antropometria pela datiloscopia. Mário Sérgio Sobrinho, A identificação Criminal, p. 62.
} 
A datiloscopia transformou-se no padrão ouro em identificação judiciária, hoje, sendo utilizado em todo o mundo. Além de permitir a identificação de um indivíduo ou corpo, possibilita a demonstração da presença de alguém em um local de investigação. Essa técnica atende a todos os requisitos científicos para a validade dos métodos de identificação e até recentemente esta posição não recebia contestações importantes. Alguns aspectos da datiloscopia serão adiante analisados.

O uso de impressões de dedos e da palma da mão iniciou-se na préhistória, havendo marcas de mãos e dedos de homens pré-históricos em cavernas de diversas partes do mundo, como a Índia, a França e a Espanha. Na Antigüidade, os babilônios selavam contratos com a impressão dos dedos e os chineses fabricavam selos de argila com impressões digitais para uso em cartas e documentos. Não se pode afirmar, porém, que essas impressões fossem utilizadas como método de identificação. Eram, antes, usadas como uma de marca de propriedade ou de autenticação de um acordo ${ }^{133}$.

Em 1668 Marcello Malpighi, anatomista italiano, descreveu as estrias de várias formas na extremidade dos dedos em sua obra De externo tactus organus. Não fez, entretanto, nenhuma menção dessas características como forma de identificação. Outros autores desde então, estudaram as estrias cutâneas, tais como o inglês Nehemiah Grew, o holandês Govard Bidloo, e os alemães J. C. A. Meyer e Thomas Bewick. Meyer expôs a teoria de que as estrias cutâneas nunca se repetiriam entre os indivíduos. O tcheco Johannes Evangelist Purkinje (em sua língua natal Jan Evangelista Purkyně) criou em 1823 uma classificação dessas estrias por suas formas, sugerindo-as como método de identificação humana ${ }^{134}$.

A história da utilização moderna de impressões digitais como meio de identificação começou no século XIX, por obra de cidadãos britânicos em especial William Herschel, Edward Richard Henry, e Henry Faulds. Estes pioneiros utilizaram as impressões digitais como forma de identificação de criminosos e de controle dos trabalhadores. Em seus trabalhos foram reconhecidas a perenidade das estrias cutâneas e a importância das

\footnotetext{
${ }^{133}$ Note-se, que, ALMEIDA Jr. cita um texto do autor João de Barros (historiador e gramático português do século XVI, donatário no Brasil, autor das Décadas da Ásia de onde foi retirada essa observação) em que este justifica o uso dessas impressões digitais na Ásia "por ser natural da pessoa, e mais certo e verdadeiro que os artificiais, que se podem falsificar", Lições de medicina legal, p. 22.

${ }^{134}$ Adriano R. L. FIGINI et al. Identificação humana, p. 12-13.
} 
impressões digitais encontradas nas cenas de crimes como fator de identificação dos criminosos. $^{135}$.

Outro britânico, Francis Galton, tornou-se um dos pioneiros da datiloscopia com a publicação de sua obra de 1882, Finger Prints ${ }^{136}$. Nela, Galton descreveu os pontos característicos que permitiriam a identificação dos indivíduos a partir das impressões digitais. O interesse de Galton no método era o estudo da hereditariedade e dos antecedentes raciais, sua especialidade. Sustentou a imutabilidade e a perenidade das estrias cutâneas, tendo calculado que a probabilidade de ocorrência de repetições era de 1 para 64 bilhões. Além disso, propôs métodos para classificação e registro das impressões digitais, considerando esse sistema superior a Bertillonagem que surgia naquele momento como sistema de identificação ${ }^{137}$. A partir de seu trabalho criou-se o sistema de classificação conhecido como Galton-Henry. Outros sistemas surgiram, sendo importante para nós o de Vucetich, criado na Argentina e utilizado no Brasil desde 1903.

As impressões digitais, plantares ou palmares nada mais são do que o suor depositado sobre um suporte sólido. Por vezes, a depender da superfície em que foram apostas, as impressões digitais são diretamente observáveis, as chamadas impressões visíveis. Mais das vezes, porém, as impressões têm de ser reveladas por meio de técnica adequada, utilizando-se reagentes químicos que reagem com os componentes do suor ${ }^{138}$. Estas impressões são denominadas latentes.

O suor humano é constituído de compostos orgânicos e inorgânicos. Dentre os primeiros destacam-se os aminoácidos, a uréia, o ácido lático, açúcares, ácido úrico e outros. Os inorgânicos são os cloretos, amônia, sulfatos, fosfatos e íons metálicos ${ }^{139}$.

Além das impressões digitais, plantares e palmares criadas pela deposição de suor nas superfícies é possível obter o desenho das cristas papilares por impressão em materiais ou líquidos que as moldem, como sangue, pastas ou massas, areia e cimento e outras substâncias (impressões moldadas ou modeladas) ${ }^{140}$.

\footnotetext{
${ }^{135}$ Adriano R. L. FIGINI et al. Identificação humana, p. 19-20.

136 Ibid., p. 20.

${ }^{137}$ Ibid., p. 17-20.

${ }^{138}$ Ibid., p 74 a 76.

${ }^{139}$ Ibid., p. 26-29.

${ }^{140}$ Ibid., p. 165-175.
} 
As papilas cutâneas surgem a partir do $6^{\circ}$ mês de vida intrauterina $^{141}$, segundo alguns autores ou do $2^{\circ}$ ao $4^{\circ}$ mês, segundo outros ${ }^{142}$, surgindo então, os desenhos papilares que nunca mais desaparecem ou alteram-se ao longo do tempo. Mesmo se destruídas, refazem-se com o mesmo desenho anterior ${ }^{143}$. Resistem após a morte até a putrefação ${ }^{144}$. Esses desenhos são muito variáveis não se reproduzindo exatamente nem em gêmeos homozigóticos.

A variabilidade e a irrepetibilidade dos desenhos papilares explicase pela combinação de dois processos sujeitos à aleatoriedade. Um deles é sua determinação genética que é de natureza poligênica, isto é, eles são a expressão de um grande número de genes situados em diversos cromossomos diferentes. O outro é a influência do ambiente fetal, como o fluxo do líquido amniótico, a fricção de partes do feto contra os anexos embrionários, $\mathrm{pH}$ local e outros. Em outras palavras, o genótipo que determina as cristas papilares influencia o fenótipo final, mas não o determina de forma preponderante, como, aliás, ocorre com quase todas características orgânicas.

A inexistência de cristas papilares idênticas em dois indivíduos pode ser explicada pela natureza estocástica de seu processo de formação ${ }^{145}$.

Papiloscopia e datiloscopia não são sinônimas. A primeira refere-se ao estudo das papilas e cristas dérmicas em toda a superfície da pele, ao passo que a segunda é espécie da primeira, ou seja, é o estudo das papilas dérmicas da extremidade dos dedos das mãos ${ }^{146}$. Na prática, isto significa que a papiloscopia estuda as cristas dérmicas das palmas das mãos e plantas dos pés além das papilas dos dedos das mãos.

A classificabilidade dos desenhos digitais baseia-se na repetição de determinadas disposições das cristas e sulcos papilares bem como os poros existentes na ponta dos dedos. Estes elementos são as linhas albodatiloscópicas, os pontos característicos e os deltas. As linhas albodatiloscópicas são alterações patológicas adquiridas, mas não perenes dos sulcos e cristas. Os pontos característicos são acidentes nas cristas e sulcos que formam

\footnotetext{
${ }^{141}$ Flamínio FÁVERO, Medicina legal, p. 142.

142 Sebastião A.P. SAMPAIO, Raymundo M. CASTRO e Evandro A. RIVITTI, Dermatologia básica, p. 2 e 3.

${ }^{143}$ Flamínio FÁVERO, Medicina legal, p.143.

${ }_{144}$ Adriano R. L. FIGINI et al. Identificação humana, p. 160.

145 Edwards P. RICHARDS, Phenotype v. genotype: Why identical twins have different fingerprints? In http://www.forensic-evidence.com/site/ID/ID Twins.html acesso em 04 de maio de 2007.

${ }^{146}$ Eduardo R.A. DEL-CAMPO, Medicina legal, p. 72.
} 
desenhos especiais. Sua denominação é variável, havendo o ponto, a ilhota, cortada, bifurcação e outros. Alguns autores os denominam minúcias ${ }^{147}$.

Os desenhos papilares beneficiam-se de diversas tecnologias de imagem e informática para a obtenção das impressões e seu arquivamento, fato que permite sua utilização como matriz de identificação biométrica. Também a fase de comparação entre amostras e os dados do arquivo podem ser automatizados aumentando em muito o rendimento e a segurança da técnica. Como exemplo desses sistemas, pode-se citar o AFIS (Automated Fingerprint Identification System), utilizado inclusive pelo FBI norte-americano como banco de impressões digitais de indivíduos investigados criminalmente para comparações futuras ${ }^{148}$.

Recentemente, têm surgido questionamentos sobre a unicidade dos desenhos papilares e da possibilidade de reconhecimento objetivo das semelhanças entre duas impressões digitais. Essas objeções, levantadas por poucos autores e apresentadas em casos criminais julgados em cortes dos Estados Unidos, não lograram abalar a credibilidade científica e a validade jurídica da datiloscopia, já que nos casos apresentados como exemplos de falhas, houve comprovação de erro humano ou fraude ${ }^{149}$.

Entre as técnicas de identificação judiciária figura atualmente a biometria. É esta modalidade de identificação que será vista em detalhes a seguir.

\subsubsection{Biometria}

Biometria, ou sistema de identificação biométrico é "um método automatizado de reconhecimento de padrões que busca a identidade de uma pessoa por algumas de suas características físicas ou comportamentais" ${ }^{„ 150}$. Do ponto de vista da segurança das informações, ou seja, do controle do acesso e utilização de sistemas informatizados, biometria é "a verificação da identidade de um indivíduo através (sic) de uma característica única inerente a essa pessoa por meio de processos automatizados ... para autenticação de usuários" "151. Segundo Jain e Ross "biometria é a ciência da determinação da

\footnotetext{
${ }^{147}$ Eduardo R.A. DEL-CAMPO, Medicina legal, p. 87.

148 Pedro Luis Kantek Garcia Navarro, “AFIS" in http://www.pr.gov.br/batebyte/edicoes/2001/bb111/afis.htm, acesso em 25 de agosto de 2007.

149 Andre A. MOENSSENS, "The reability of fingerprinting identification: a case report" disponível em http://www.forensic-evidence.com/site/ID/pollak2002.html, acesso em 25 de agosto de 2007.

${ }^{150}$ Eduardo R.A. DEL-CAMPO, Medicina legal, p. 66.

${ }^{151}$ Douglas VIGLIAZZI, Biometria: medidas de segurança, p. 2. Ver página 19
} 
identidade de um indivíduo baseada nos atributos físicos, químicos ou comportamentais da pessoa" ${ }^{\prime 152}$.

O termo biometria é inapropriado porque, a rigor, biometria é qualquer técnica estatística de mensuração de uma característica biológica, com finalidades na maioria das vezes médicas. Em perícia médico-legal, o termo exame biométrico compreende "a avaliação do estado de higidez física e mental do periciado" com a finalidade de atender a requisitos legais em diversas áreas, como na penal, civil, administrativa, habilitadora, previdenciária e outras. $\mathrm{O}$ exame médico para a habilitação de dirigir veículos é um exame biométrico $^{153}$.

Biometria, como aqui é entendida, é uma técnica de identificação ou autenticação que utiliza características biológicas reconhecíveis, seja por suas medidas, seja por seu aspecto único e identificável. A maioria dessas técnicas não realiza propriamente uma mensuração, mas sim um registro e posterior comparação de padrões biológicos estruturais ou funcionais. Um termo mais apropriado poderia ser autenticação biométrica ${ }^{154}$.

Releva notar, na definição, o termo "automatizado" ou automático. Toda técnica biométrica é realizada por equipamentos automáticos de obtenção, registro e comparação de dados biológicos considerados únicos, perenes e classificáveis e, portanto, cientificamente válidos para a identificação humana. As características biológicas utilizadas nas técnicas biométricas foram, em sua maioria, objeto de antigos métodos de identificação. Exemplos desses métodos já foram citados, como o sistema oftalmométrico de Capdeville e o oftalmoscópico de Levihnson. Outras técnicas de biometria ampliam possibilidades de métodos consagrados, como a datiloscopia e o retrato falado. Todos os métodos biométricos são aplicações da tecnologia atual na identificação de características biológicas já reconhecidamente únicas. De certa forma são atualizações das técnicas de Bertillon ${ }^{155}$. É o avanço tecnológico que tem determinado o crescimento em número de novas técnicas e sua aplicação cada vez mais intensa em diversas atividades humanas.

As técnicas biométricas podem ser utilizadas para a identificação de um indivíduo ou para a verificação ou autenticação da identidade de alguém. A primeira finalidade é descrita como comparação "um-para-muitos" ou 1-n. A segunda é a comparação

\footnotetext{
${ }^{152}$ Anil K. JANIN, Patrick FLYNN e Arun A. ROSS, Handbook of biometrics, p. 1.

${ }^{153}$ Hermes Rodrigues ALCÂNTARA, Perícia médica judicial, p. 47.

${ }_{155}^{154}$ Ibid., p. 1-2.

${ }^{155}$ Hermes Rodrigues ALCÂNTARA, Perícia médica judicial, p. 426.
} 
"um-para-um" ou 1-1 ${ }^{156}$. Para desempenhar estas tarefas, como em qualquer método de identificação, é preciso, em primeiro lugar, recolher os dados dos indivíduos em um arquivo que será utilizado para identificá-los em comparação posterior.

Esse arquivo de dados para biometria é um arquivo informático. $\mathrm{Na}$ produção desse arquivo, emprega-se uma interface entre o sistema informático e a característica biológica utilizada pelo método. Essa interface é realizada com "scanners", microfones, câmeras, leitores ópticos e outros equipamentos variáveis conforme o método biométrico.

Uma vez mais, tome-se como exemplo a papiloscopia. $\mathrm{Na}$ biometria das impressões digitais, um "scanner" de sulcos e estrias papilares capta a imagem dessas estrias da polpa dos dedos diretamente ou indiretamente por meio de imagens das impressões digitais. As imagens assim coletadas são submetidas a alguns algoritmos ${ }^{157}$. Um algoritmo é um programa informático que comanda diversas operações a fim de obter determinado resultado, neste caso, o registro de características biológicas. Inicialmente, o programa verifica a qualidade da imagem obtida. Se a imagem não atende aos padrões de qualidade, o programa pode tentar melhorá-la ou outra amostra deve ser obtida. Se a qualidade da imagem for adequada, porém, o programa processa essas informações. A imagem digitalizada é examinada para localizar os pontos característicos - os deltas - e demais disposições das estrias papilares (tecnicamente denominadas minúcias) que servem para individualizar cada impressão digital. Localizadas e registradas as minúcias presentes, esses dados são em seguida criptografados para maior segurança. Idealmente, o volume de dados resultante desse algoritmo deve ser pequeno para facilitar seu manejo. Finalmente, são esses dados armazenados no banco de dados. Outros dados não obtidos diretamente pelo sistema também podem ser acrescentados, como por exemplo, o dedo analisado, a lateralidade da mão em que se localiza e outros ${ }^{158}$.

A identificação do indivíduo que está fornecendo a amostra inicial é necessariamente externa ao sistema biométrico. Isto é, a identidade do proprietário da amostra é garantida por um sistema de identificação oficial, como os dos institutos de identificação das Secretarias de Segurança de cada estado brasileiro. Somente se os indivíduos

\footnotetext{
${ }_{156}^{156}$ Douglas VIGLIAZZI, Biometria: medidas de segurança, p. 19.

${ }^{157}$ Algoritmo é um "Conjunto de regras ordenadas destinadas à obtenção de um resultado". Aurélio BUARQUE DE HOLANDA FERREIRA, Novo Aurélio século XXI, p. 96.

${ }^{158}$ Pedro Luis Kantek Garcia NAVARRO http://www.pr.gov.br/batebyte/edicoes/2001/bb111/afis.htm acesso em 29 de agosto de 2007.
} 
estiverem realmente assim identificados será possível fazer a comparação um entre muitos, ou em outras palavras, somente assim será possível identificá-los biometricamente. Já a verificação ou autenticação (comparação um para um) prescinde dessa medida. Será assim possível dizer que aquele indivíduo que se apresenta em uma segunda ocasião já tinha fornecido sua amostra ao sistema anteriormente ${ }^{159}$.

Cada amostra das características biológicas processadas informaticamente recebe o nome de "template", termo inglês correspondente a modelo ou gabarito $^{160}$. O modelo obtido do indivíduo a autenticar ou identificar será comparado ao modelo original armazenado sob forma criptografada no arquivo. Esse segundo molde será tratado informaticamente da mesma forma que o primeiro, por meio de um algoritmo de reconhecimento semelhante ao utilizado na elaboração do molde original ${ }^{161}$.

Os moldes são comparados por computadores denominados "match servers" ${ }^{162}$ com os dados armazenados no banco de dados. A rapidez da comparação depende da velocidade e do número desses computadores. Se o sistema operar na autenticação de alguém, os dados do molde de teste são comparados com os dados armazenados para aquele indivíduo, respondendo, em geral rapidamente, se a correspondência existe ou não. Há sistemas mais simples que armazenam um número limitado de informações no próprio equipamento de captura dos dados biométricos e realizam sem a ajuda de computadores a comparação entre os modelos biométricos analisados.

$\mathrm{Na}$ verificação ou autenticação, o objetivo do teste é comprovar que alguém é de fato quem afirma ser. Para isto, suas características biométricas são apresentadas ao sistema, que processará os dados como foi feito no registro inicial, obtendo um modelo biométrico que será comparado com o molde da pessoa cuja identidade está sendo invocada, molde esse que se encontra arquivado no banco de dados. O resultado esperado é a confirmação da identidade ou autenticação ${ }^{163}$.

Os sistemas de identificação (os que fazem a comparação "umpara-muitos") apresentam duas respostas possíveis, a identificação positiva e a negativa. $\mathrm{Na}$

\footnotetext{
${ }^{159}$ John R. VACCA, Biometric technologies and verification systems, p. 23 e 24.

160 "Gabarito: 4. Instrumento que serve de molde para a representação gráfica de elementos arquitetônicos, mobiliários e símbolos diversos" in: Aurélio BUARQUE DE HOLANDA FERREIRA, Novo Aurélio século $X X I$, p. 958.

${ }^{161}$ John R. VACCA, Biometric technologies and verification systems, p. 25 e 26.

${ }_{162}$ Pedro Luis Kantek Garcia NAVARRO http://www.pr.gov.br/batebyte/edicoes/2001/bb111/afis.htm acesso em 29 de agosto de 2007.

${ }^{163}$ Ibid., p. 24.
} 
identificação positiva, o sistema compara o modelo de teste com o universo de todos os dados do banco para ver se há correspondência com os dados de alguém ali armazenados. A resposta esperada neste caso é a confirmação dessa correspondência, ou seja, que haja uma amostra no universo das amostras armazenadas que corresponde àquela testada. É o caso da comprovação de que uma pessoa está incluída entre os usuários com direito a um benefício concedido pela seguridade social, porque sua característica biométrica corresponde às de alguém identificado no banco de dados como portador desse direito. Na identificação negativa, os dados do molde de teste são comparados com os armazenados para comprovar que não há, naquele universo de dados, nenhum que lhes corresponda. A não correspondência comprova, por exemplo, que aquele usuário não utilizou ainda determinado benefício a que tem direito ${ }^{164}$.

Os métodos de biometria devem atender aos requisitos de validade científica de qualquer método de identificação, a saber, a unicidade das características estudadas, sua imutabilidade, sua variabilidade (que engloba a classificabilidade) e sua praticabilidade. Além destes requisitos, os autores descrevem alguns específicos para a biometria: a desempenho, a universalidade, a mensurabilidade, a aceitação e a segurança ${ }^{165}$.

A desempenho ou desempenho engloba os itens precisão do teste, sua velocidade de execução, sua robustez e finalmente sua confiabilidade. A precisão é aferida pelas taxa de falsa rejeição (FRR, sigla do inglês "False Rejection Rate", também conhecida como "False Non-Match Rate", FNMR) e a taxa de falsa aceitação (FAR, ou "False Acceptance Rate" também conhecida como "False Match Rate", FMR) e taxa de falha no cadastramento (FTER para "Failure to Enroll Rate") ${ }^{166}$. A taxa de falsa rejeição refere-se à quantidade de pessoas registradas no banco de dados que não são reconhecidas pelo sistema biométrico. Inversamente, a taxa de falsa aceitação refere-se à quantidade de pessoas não registradas pelo sistema que são assim consideradas pelo método. Idealmente, os dois índices teriam que ser iguais a zero, o que infelizmente não ocorre na prática. Há uma relação inversa entre os dois índices. Quanto maior a exigência para que um modelo seja considerado correspondente a outro já arquivado, maior a possibilidade de que uma correspondência real não seja reconhecida. Da mesma forma, quanto menos for exigido para se reconhecer uma amostra, maior o número de amostras não correspondentes consideradas positivas.

\footnotetext{
${ }_{164}$ John R. VACCA, Biometric technologies and verification systems, p. 25 e 26.

165 Eduardo R.A. DEL-CAMPO, Medicina legal, p. 67, Anil K. JANIN, Patrick FLYNN e Arun A. ROSS, Handbook of Biometrics, p. 15.

${ }^{166}$ Douglas VIGLIAZZI, Biometria: medidas de segurança, p. 72; John R. VACCA, Biometric Technologies and Verification Systems, p. 38.
} 
Em suma, quanto maior a FRR (FNMR) menor a FAR (FMR). Alguns fabricantes criaram a "Equal Error Rate" (EER) ou taxa de erro igual que é o ponto em a taxa de falsa aceitação (FAR ou FMR) iguala a taxa de falsa rejeição (FRR ou FNMR). Um sistema que atendesse a este requisito apresentaria a mesma probabilidade de aceitar ou rejeitar erroneamente uma amostra apresentada a ele. Esta simplificação não encontra valor prático na vida real, porque os sistemas biométricos têm que privilegiar um desses dois aspectos em sua utilização. Por exemplo, um sistema de verificação da identidade para uso em caixas eletrônicos deve ter uma baixa FRR e uma FAR mais alta para que os clientes legítimos possam utilizar o equipamento com mais facilidade. Outro sistema que controlasse o acesso de pessoas a um determinado lugar de alta segurança, deveria idealmente ter uma baixa FAR e uma FRR mais elevada, para que a segurança do local pudesse ser privilegiada. As taxas FAR e FRR em conjunto definem a acurácia do sistema biométrico.

A taxa de falhas no cadastramento (FTER) é outro parâmetro de precisão do método e refere-se ao número de amostras que não se consegue processar por qualquer motivo, seja em razão do tipo de característica biológica utilizada, seja por razões técnicas do método. $\mathrm{O}$ número de pessoas que não possuem a parte do corpo exigida para utilizar o método (1 a 3\%) não está contido nesse índice ${ }^{167}$.

A velocidade de execução refere-se ao tempo que o sistema leva para captar a característica biológica e processá-la, tanto no cadastramento quanto na etapa de identificação ou autenticação. Também deve ser avaliado o tempo para a comparação entre as amostras. Atualmente, a maioria dos sistemas biométricos realiza estas funções em segundos. Para que este desempenho seja possível, os processadores e servidores devem ter alta capacidade e velocidade.

A robustez e a confiabilidade referem-se às características físicas do sistema, quanto à operação e facilidade de manutenção do mesmo. Equipamentos frágeis não conseguem atender aos requisitos de confiança em sua utilização pelos usuários.

O segundo requisito de validade dos sistemas biométricos é a universalidade, que vem a ser a característica que permite a utilização do método em um número grande de usuários. $\mathrm{O}$ caractere biométrico ideal é aquele que todos os indivíduos a serem identificados possuem. Como já citado, em geral, de 1 a $3 \%$ das pessoas não apresentam a estrutura orgânica utilizada como caractere biométrico, independentemente do

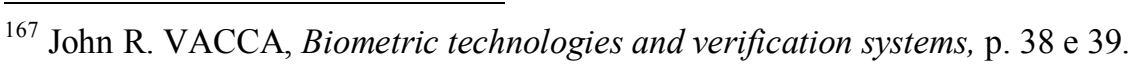


sistema utilizado. Qualquer método que apresente taxas maiores do que isto não pode ser considerado de uso universal.

A mensurabilidade é a capacidade de adquirir os dados sobre o traço biométrico e digitalizá-los, para posterior processamento de características representativas do mesmo ${ }^{168}$.

A aceitação é a capacidade do método ser utilizado pelos usuários sem causar resistência. Qualquer método que cause dor ou constrangimento no cadastramento ou na fase de verificação ou identificação sofrerá grande resistência por parte dos usuários.

Finalmente, como último requisito de validade, mencione-se a segurança, que é capacidade de resistir a possíveis fraudes no sistema. Todo método biométrico, como já visto, depende de uma identificação primária externa a ele, geralmente fornecida por um órgão oficial de identificação. O maior rigor possível no controle dos documentos e dados de identificação daqueles que são cadastrados é a garantia da autenticidade da identificação fornecida pelo teste. Outro ponto importante da segurança é a impossibilidade de acesso ao banco de dados por pessoas não autorizadas, que poderiam alterar os dados ou utilizá-los indevidamente. O segredo dos algoritmos utilizados além da criptografia dos dados dificulta a invasão do sistema por indivíduos não autorizados. Cada método, além disso, deve possuir as salvaguardas próprias para que características biológicas fraudulentas, como fotos de íris ou de impressões digitais de outros indivíduos não sejam utilizadas para induzir o sistema a erro.

Os algoritmos e a criptografia dos métodos biométricos têm sido objeto de intenso trabalho de padronização para garantia da segurança dos mesmos e para possibilitar a troca de informações entre os diversos bancos de dados. Outra preocupação é o estabelecimento de padrões de avaliação de desempenho dos métodos em uso ou dos que estão surgindo. Nos Estados Unidos, diversos grupos de trabalho estão desenvolvendo padrões de desempenho biométrico sob o patrocínio do National Institute of Standards and Technology (NIST) da National Security Agency (NSA) e do American National Standards Institute (ANSI). As indústrias uniram-se com a mesma finalidade no Biometric Consortium (BC). Em nível internacional, o International Organization for Standardization (ISO) e a

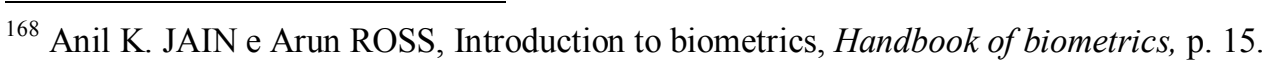


União Européia têm também desenvolvido trabalhos de padronização de tecnologias e equipamentos $^{169}$. No Brasil, ainda não existem trabalhos de monta equivalentes.

Esses institutos procuram prover APIs ${ }^{170}$ que permitam múltiplos níveis de implementação de programas biométricos, prover "frameworks" comuns, suportando múltiplas técnicas biométricas, promover a segurança dos sistemas e prover um processo de desenvolvimento e propriedade independentes do distribuidor ${ }^{171}$.

Há diversas técnicas biométricas correntemente em uso. As mais utilizadas são o reconhecimento das impressões digitais, reconhecimento da face, geometria das mãos e dedos, reconhecimento da íris, reconhecimento dos vasos da retina, dinâmica do andar, dinâmica da digitação, reconhecimento da voz, e reconhecimento da forma de assinar. Há outras técnicas em estudo, como reconhecimento do pulso sanguíneo, identificação do leito ungueal, identificação da salinidade corpórea, reconhecimento da impressão palmar, reconhecimento dos padrões venosos, termografia facial, análise de poros sudoríparos, reconhecimento da apreensão das mãos, odor corpóreo, formato do pavilhão auditivo, luminescência da pele, padrões de ondas cerebrais, identificação por nariz eletrônico, reconhecimento das pegadas, DNA, e dinâmicas do pé. O método de cada uma delas obedece aos algoritmos citados anteriormente. Cada um deles apresenta atualmente graus diferentes de precisão e praticidade, podendo ser úteis em algumas situações, mas não em outras ${ }^{172}$.

\subsubsection{Biometria e ciência forense}

Como já exposto anteriormente, a biometria pode ser considerada a automação de processos identificadores utilizados no passado, especialmente a antropometria de Bertillon. A biometria criou a possibilidade de triar rapidamente indivíduos por suas características físicas, facilitando o trabalho dos peritos forenses. No entanto, o trabalho de avaliar as evidências e identificar os envolvidos é atribuição do perito, não sendo admitidas evidências informáticas puras em juízo. Melhor, por isso, considerar as técnicas biométricas filtros de suspeitos para que os peritos determinem por técnicas específicas a identidade dos

\footnotetext{
169 John R. VACCA, Biometric technologies and verification systems, p. 6 a 11.

170 API (Application programming interface) é um conjunto de rotinas ou padrões estabelecidos por um programa informático para que outros programas possam utilizar suas propriedades. É uma forma de utilizar os recursos de um programa por outro. Por exemplo, o programa Windows possui diversos APIs acessíveis a outros programas para que estes possam utilizar recursos do próprio Windows em suas operações, por exemplo, a data, copiar e colar dados de texto e etc.

${ }^{171}$ Douglas VIGLIAZZI, Biometria: medidas de segurança, p. 5.

172 John R. VACCA, Biometric technologies and verification systems, p. 27 a 37.
} 
mesmos. A perícia da identificação realizada pelos métodos descritos anteriormente tem validade científica e competência técnica superior, sendo esse fato reconhecido em juízo. ${ }^{173}$.

Há diferenças entre a biometria e identificação forense. A primeira diferença é que as técnicas biométricas são sistemas que estabelecem relações entre características apresentadas em determinado momento e modelos informáticos dessas características armazenadas em bancos de dados. O resultado esperado é a correspondência ou não-correspondência entre as duas amostras. O objetivo principal não é a determinação da identidade do portador das mesmas, mas sim, estabelecer relações de semelhança. Já para o perito, o processo de identificação forense visa ao estabelecimento da identidade do vivo, do cadáver ou do material biológico apresentado à sua análise. Por isso, afirmou-se anteriormente que a biometria pode funcionar como um método de triagem entre indivíduos a serem posteriormente identificados pelo perito forense ${ }^{174}$.

Outra diferença está na terminologia envolvida. Na biometria das impressões digitais uma amostra de impressão pode ser comparada aos dados arquivados e as conclusões podem ser: individualização do doador, exclusão de alguém suspeito ou resultado inconclusivo. As duas primeiras conclusões são categóricas: o indivíduo é identificado ou excluído como suspeito. Na resposta inconclusiva, porém, pode-se graduar a resposta pelos termos possível, provável ou muito provável. É nesse tipo de conclusão que as probabilidades são realmente avaliadas, já que o perito deve pesar as evidências a favor e contra a identificação do fragmento dentro do contexto da investigação.

No entanto, a aproximação probabilística deveria ser, segundo alguns autores, sempre utilizada ao invés de respostas categóricas como individualização ou exclusão. O campo paradigma para isso é a identificação pelo DNA. Nessa área, são apresentadas em juízo as probabilidades estatísticas de identificação ou da paternidade, referindo-se ao caso estudado. É sopesando-se as probabilidades estatísticas que uma decisão judicial baseada em um teste de DNA pode aproximar-se de um resultado justo, não havendo respostas categóricas como na datiloscopia ${ }^{175}$.

No campo da identificação datiloscópica sempre se utilizaram as respostas categóricas. Porém, recentemente, casos demonstraram que diversas variáveis,

${ }^{173}$ Damien DESSIMOZ e Christophe CHAMPOD, Linkage between Biometrics and Forensic Science, in Handbook of biometrics, p.427.

${ }^{174}$ Ibid., p. 426.

${ }^{175}$ Ibid., p. 427. 
especialmente relacionadas ao fator humano podem resultar em erros grosseiros na identificação de impressões latentes. Nesse caso, em aplicação do Princípio de Daulbert ${ }^{176}$, análises de diversos especialistas podem divergir da opinião cientificamente dominante e serem aceitas em juízo, inclusive contrariamente à evidência datiloscópica categórica emitida por um especialista na área ${ }^{177}$.

Os autores que defendem apresentações de resultados de identificação em probabilidades e não por respostas categóricas propõem a fórmula da taxa de certeza obtida pela fórmula:

$$
L R=\frac{p(E / S, I)}{p\left(E / S^{\prime}, I\right)}
$$

Onde $L R$ é a taxa de certeza ("likelihood rate"), $E$ é o resultado da comparação entre a fonte e o arquivo de dados do suspeito, $S$ é a posição da acusação,ou seja, que a fonte é do suspeito e $S$ ' é a posição da defesa, ou seja, a fonte não é do suspeito, cotejado pelos dados relevantes para o caso, $I$.

A taxa de certeza leva o perito forense a avaliar as probabilidades de correspondência entre os dados obtidos pelos métodos utilizados à luz das reais circunstâncias do caso concreto e da desempenho do método identificador utilizado. A partir dessa análise, o perito pode apresentar seu laudo pericial focado em probabilidades e não em afirmações categóricas, como individualização ou exclusão ${ }^{178}$.

Uma terceira diferença entre identificação biométrica e forense está na perda de seletividade das características biométricas obtidas em ambiente forense, já que nessas situações, o doador não é cooperativo e a amostra biométrica do local do crime raramente atinge os padrões mínimos de qualidade pata uma comparação segura.

\footnotetext{
176 Daubert v Merrel Dow Pharmaceuticals. Nesse caso a Suprema Corte norte-americana alterou a jurisprudência até então vigente, que declarava ser válida em juízo a opinião do especialista apenas se esta coincidisse com a opinião geral da comunidade científica sobre o assunto. Esse precedente datava de 1923 e era conhecido como "Frye test" por que havia sido estabelecido no caso "Frye vs. United States". O princípio de Daubert inclui outros requisitos ao da aceitação geral da comunidade científica, como a validade do método científico que revelou a opinião do especialista, se esta foi revisada e aprovada por outros especialistas, e a taxa de erro envolvida no processo. Além disso, o juiz pode considerar a opinião irrelevante para o caso. O papel do juiz é de um guardião ("gatekeeper"), trazendo para o processo somente opiniões relevantes e cientificamente confiáveis. Ver Robert EPSTEIN, Fingerprints meet Daubert: the myth of fingerprint "science" is revealed in http://www.fd.org/Publications?SpecTop/fingerprintlawreview.pdf acesso em 25 de janeiro de 2008.

177 Robert EPSTEIN, Fingerprints meet Daubert: the myth of fingerprint "science" is revealed in http://www.fd.org/Publications?SpecTop/fingerprintlawreview.pdf acesso em 25 de janeiro de 2008.

${ }_{178}$ Damien DESSIMOZ e Christophe CHAMPOD, Linkage between biometrics and forensic science, in Handbook of biometrics, p. 429.
} 
Como é sabido, neste trabalho serão analisadas as técnicas biométricas realizadas a partir da análise das estruturas oculares, a saber, o reconhecimento pela íris e pelas estruturas retinianas, e que podem ser utilizadas na identificação forense. A seguir, serão revisadas as bases anatômicas e tecnológicas desses métodos biométricos. 
PARTE II

BIOMETRIA OCULAR - ASPECTOS TÉCNICOS 


\section{CAPÍTULO III - BASES BIOLÓGICAS PARA A BIOMETRIA DAS ESTRUTURAS OCULARES}

\subsection{ANATOMIA DO BULBO DO OLHO ${ }^{179}$}

Os bulbos dos olhos situam-se em cada lado do plano sagital da cabeça, separados pelo nariz na região orbital. Estão contidos na região orbitária, protegidos pela órbita óssea que os contêm. Embora a denominação globo seja comumente usada, os olhos não são exatamente esféricos, sendo mais bem comparados a duas esferas colocadas uma à frente da outra ${ }^{180}$. Por essa razão, o diâmetro antero-posterior é maior que qualquer outro diâmetro ocular. O globo ocular tem como diâmetro médio $24 \mathrm{~mm}$ no eixo anteroposterior, $23 \mathrm{~mm}$ no vertical e $23,5 \mathrm{~mm}$ no horizontal ${ }^{181}$.

A parte anterior do bulbo do olho denomina-se pólo anterior e inclui a córnea, a câmara anterior, a íris, a câmara posterior, a lente (cristalino) e o corpo ciliar. A região exatamente oposta, onde se localiza a retina, o nervo óptico, a corióide (corióide) e a região posterior da esclera é conhecida como pólo posterior. O conteúdo do bulbo do olho posteriormente ao cristalino é preenchido pelo tecido gelatinoso conhecido como corpo vítreo. Este verdadeiro gel totalmente transparente é formado por fibras de colágeno e líquido, conhecidos respectivamente como estroma e humor vítreos.

Tanto a câmara anterior quanto a posterior são preenchidas por um fluido. É o chamado humor aquoso. Este líquido é produzido pelo corpo ciliar na câmara posterior e é drenado na câmara anterior. A íris divide as duas câmaras permitindo através da pupila o fluxo do humor aquoso.

\footnotetext{
179 A nomenclatura aqui utilizada é a da Terminologia Anatômica Internacional, segundo a tradução da Sociedade Brasileira de Anatomia. Esta terminologia foi estabelecida pela Federative Commitee on Anatomical Terminology - FCAT International Federation of Associations of Anatomists - IFAA para unificar e simplificar a nomenclatura internacional então aceita a Nomina Anatomica. Este trabalho vinha sendo realizado desde 1955 por um comitê nomeado pela IFAA para unificar os termos anatômicos, o Internacional Nomenclature Anatomical Commitee - INAC. Em 1989, no XIII Congresso da IFAA realizado no Rio de Janeiro, foi decidido que um novo comitê seria formado para reavaliar a Nomina Anatomica, em lugar do INAC, já que este havia adquirido uma independência considerada indesejável pela Federação Internacional. Assim, foi criado o FCAT, que elaborou a terminologia aqui utilizada. Nos casos em que a terminologia adotou denominação diversa da usada na prática médica, o termo utilizado por esta será apresentado entre parênteses. Sociedade Brasileira de Anatomia Terminologia Anatômica, p.189-195

${ }^{180}$ Eugene WOLFF, Anatomy of the eye and orbit, p.30.

${ }^{181}$ Ibid., p.30
} 
A retina é o tecido neural sensível à luz que é responsável pela formação das imagens que serão transmitidas ao cérebro. No pólo posterior está localizada a região da retina de maior sensibilidade à luz, responsável por cerca de $90 \%$ da acuidade visual: a mácula lútea. Também nessa região tem origem o nervo óptico, a partir de fibras originadas na retina. A nutrição dos estratos mais externos da retina é responsabilidade da corióde, tecido análogo à pia-máter cerebral.

A parede do bulbo do olho é constituída por uma túnica fibrosa denominada esclera. Esta parede contém todas as delicadas estruturas intra-oculares protegendo-as e servindo de meio de inserção de vasos, nervos e músculos do globo ocular, que chegam até ele na órbita óssea.

A órbita óssea situa-se na face, sendo formada por partes de ossos do crânio. Seu formato é aproximadamente trapezoidal ou piriforme, com o ápice voltado para a cavidade do crânio ${ }^{182}$. É formada por segmentos de sete ossos: o osso frontal, o esfenóide, a maxila, o palatino, o zigomático, o lacrimal e o etmóide. Essa estrutura óssea serve de arcabouço e de proteção ao globo ocular. Nela estão contidas todas as estruturas responsáveis pela movimentação, nutrição e sensibilidade do olho. A partir dela é que os olhos comunicamse com o encéfalo. Possui no seu ápice algumas aberturas, a fissura orbital superior, o canal óptico e a fissura orbital inferior, além de diversos pequenos forames vasculares. Essas aberturas permitem a passagem das diferentes estruturas vasculares e nervosas que constituem o conteúdo orbitário. ${ }^{183}$

O conteúdo orbitário consiste na musculatura ocular extrínseca que movimenta os globos oculares, nos vasos venosos e arteriais que os irrigam, nos nervos que são responsáveis pela sensibilidade e funções visuais propriamente ditas e em tecido conectivo que a preenche e sustenta suas estruturas. Esse tecido conectivo é formado por células adiposas e fibrosas.

A musculatura ocular extrínseca (assim denominada para diferenciá-la dos músculos intra-oculares, conhecidos como musculatura ocular intrínseca) é formada por um conjunto de seis músculos estriados: os quatro músculos retos, o superior, o medial o inferior e o lateral e dois músculos oblíquos, o oblíquo inferior e o superior. Os músculos retos, de forma simplificada, giram os olhos para cada uma das quatro direções do

\footnotetext{
${ }^{182}$ Eugene WOLFF, Anatomy of the eye and orbit, p. 1.

183 Ira S. JONES et. al., Patient examination and introduction of orbital disease in Duane's clinical ophthalmology, Vol. 2, cap. 21, p. 1.
} 
olhar, elevação e depressão, rotação medial (adução, que é a rotação para a linha média do corpo) e lateral (abdução, a rotação para a região temporal), ao redor dos eixos horizontal e vertical respectivamente. Os músculos oblíquos giram os olhos ao redor do eixo anteroposterior, em movimento contra ou a favor do relógio (respectivamente exciclodução e inciclodução), ao mesmo tempo elevando-os (oblíquo inferior) ou abaixando-os (oblíquo superior).

Os músculos retos são quase todos quase todos pelo III nervo craniano, que apropriadamente é chamado oculomotor. O oblíquo inferior também é inervado pelo oculomotor. O músculo reto lateral é inervado pelo VI nervo craniano, o abducente e o oblíquo superior é inervado pelo troclear, o IV nervo craniano.

Os músculos inserem-se no globo ocular por meio de tendões fibrosos de tecido semelhante ao da esclera. Suas outras extremidades inserem-se na órbita óssea, especialmente em uma estrutura do ápice da órbita denominada anel tendíneo comum (anel de Zinn). A única exceção é o músculo oblíquo inferior que se insere na maxila, na parede da órbita ${ }^{184}$.

Os principais vasos orbitários são a artéria oftálmica, as veias oftálmicas superior e inferior. A artéria oftálmica é ramo da carótida interna e penetra na órbita junto ao nervo óptico pelo canal óptico situado no ápice da órbita. Seus ramos formam uma grande rede de vasos muito tortuosos que irrigam os tecidos orbitários e a superfície da região frontal. Os principais ramos arteriais são a artéria central da retina, as artérias ciliares posteriores longa e curta e as artérias ciliares anteriores. A artéria oftálmica também origina ramos que irrigam os músculos extrínsecos, a região conjuntival e as pálpebras. A artéria central da retina tem a função de irrigar esta camada celular sensível à luz. As artérias ciliares posteriores e a anterior irrigam a úvea, túnica do globo que tem a íris como uma de suas $\operatorname{partes}^{185}$.

A veia oftálmica superior e a veia oftálmica inferior drenam por meio de uma intrincada rede venosa sem válvulas todas as estruturas posteriores do globo ocular. A veia oftálmica superior recebe o sangue das veias central da retina e ciliares anteriores. A veia oftálmica inferior une-se à veia oftálmica superior em seu caminho em direção ao seio cavernoso, estrutura vascular venosa situada atrás da órbita em íntima relação

\footnotetext{
${ }^{184}$ American Academy of Ophthalmology, Fundamentals and principles of ophthalmology, p. 31-33.

${ }^{185}$ Eugene WOLFF, Anatomy of the eye and orbit, p.406-412.
} 
com diversas outras estruturas vasculares como as veias orbitárias e faciais e a carótida interna, bem como com estruturas nervosas como os pares cranianos orbitários ${ }^{186}$. A veia angular situa-se na região superior da órbita recebendo sangue das veias nasais e drenando-o para a veia oftálmica superior. A veia oftálmica inferior também tem ligações com as veias facial e facial profunda. Essa complexa rede venosa com tantas interligações facilita a drenagem das órbitas e de outras estruturas faciais, já que esse sistema é um sistema de baixa pressão. Se alguma parte do sistema estiver obstruída, o fluxo pode tomar direções alternativas com facilidade ${ }^{187}$.

A rede nervosa orbitária também é rica e complexa. Os principais nervos orbitários são os seguintes: nervo óptico (II nervo craniano), nervo óculo-motor (III), troclear (IV), ramos do nervo trigêmeo (V ), abducente (VI ) e o frontal (VII ).

O nervo óptico, o II nervo craniano, merece destaque pela importância na função visual. Este nervo, na verdade, é um trato de fibras nervosas ${ }^{188}$ originadas das células ganglionares da retina. Forma-se na porção posterior do bulbo do olho, o pólo posterior, possuindo uma bainha com estruturas análogas às das meninges, o que lhe confere uma característica distintiva dos demais nervos $\operatorname{cranianos}^{189}$.O nervo óptico possui quatro partes, a saber, a intracraniana, a do canal, a orbital e a intraocular. Esta última dividese em parte pós-laminar, parte intralaminar e pré-laminar. A parte intra-ocular é o local em que as fibras retinianas que formam o nervo óptico se agrupam e saem do bulbo. Suas divisões referem-se à posição das fibras ao atravessarem a esclera, pela estrutura denominada lâmina crivosa da esclera. O nervo óptico sai da órbita pelo canal óptico passando antes pelo anel tendíneo comum (ver acima) ${ }^{190}$.

O nervo óptico tem estreita relação com as artéria e veia central da retina a partir de sua porção orbitária, sendo que esses vasos penetram no globo na região da porção laminar do nervo, na lâmina crivosa ${ }^{191}$. Na porção intra-ocular do nervo óptico, os vasos se distribuem para todos os quadrantes da retina, irrigando suas camadas mais internas.

\footnotetext{
${ }^{186}$ Eugene WOLFF, Anatomy of the eye and orbit, p.413-415.

${ }^{187}$ Ibid., p.412-417.

${ }^{188}$ American Academy of Ophthalmology, Fundamentals and principles of ophthalmology, p. 63. Trato nervoso é "um feixe de fibras nervosas que têm mesma origem, terminação e função" ("Trato" in Aurélio p. 1993).

${ }^{189}$ Ibid., p. 64.

${ }^{190}$ Eugene WOLFF, Anatomy of the eye and orbit, p. 325.

${ }^{191}$ American Academy of Ophthalmology, Fundamentals and principles of ophthalmology, p.64.
} 
Ao exame fundoscópico ${ }^{192}$ estuda-se a distribuição desses ramos vasculares, distribuição esta que pode servir como método de identificação já que é aleatória, única e razoavelmente imutável. Observando-se o nervo óptico no pólo posterior do bulbo do olho vê-se uma estrutura discóide denominada disco do nervo óptico. No disco do nervo óptico encontra-se uma depressão de tamanho variável denominada escavação. A origem dessa escavação é a reabsorção do tecido embrionário conhecido como papila de Bergmeister conseqüente à atrofia da artéria hialóideia primária existente no período embrionário, o que ocorre por volta do terceiro mês de vida ${ }^{193}$. Essa estrutura adquire importância em doenças que promovem o aumento dessa escavação como conseqüência da destruição das fibras nervosas do nervo óptico, condição conhecida como glaucoma ${ }^{194}$.

O bulbo do olho é formado por três túnicas concêntricas: a túnica fibrosa, a túnica vascular e a interna.

A túnica fibrosa divide-se em uma porção transparente denominada córnea e uma opaca denominada esclera. Ambas são constituídas de células fibrosas e fibras de colágeno, tendo como função a proteção das túnicas vascular e interna (a esclera) e a focalização e transmissão da luz para o processo visual (córnea). A esclera tem coloração esbranquiçada em sua maior parte, sendo que é o que popularmente denomina-se "branco dos olhos". A esclera apresenta diversas aberturas para que vasos e nervos entrem no globo ocular. As fibras esclerais continuam-se com os tendões dos músculos extrínsecos que nela se inserem.

A córnea divide-se da esclera por um sulco demarcatório na região denominada limbo da córnea. A córnea apresenta curvatura maior do que a da esclera, o que lhe confere poder dióptrico maior. A curvatura anterior da córnea é de 7-8 mm e posterior é de 5-6 mm. Sua espessura é maior na proximidade do limbo (ver acima) do que no centro. A transparência da córnea é garantida pela ausência de vasos sangüíneos e pela ação de sua camada interna denominada epitélio posterior (endotélio). As camadas da córnea são em número de cinco, da parte anterior para a posterior: epitélio, lâmina limitante anterior

\footnotetext{
${ }^{192}$ O exame fundoscópico é o realizado para avaliar do fundo do olho, região que se situa no lado oposto ao da córnea que é a parte transparente frontal do olho. Nessa região pode-se visualizar a parte central da retina, seus vasos sangüíneos e a parte intra-ocular do nervo óptico, denominada nesse exame de disco óptico.

${ }^{193}$ Eugene WOLFF, Anatomy of the eye and orbit, p. 437.

${ }^{194}$ M. Bruce SHIELDS, A study guide for glaucoma, p. 77-98;, Deborah PAVAN-LANGSTON, Manual of ocular diagnosis and therapeutics p. 254.
} 
(Bowman), substância própria, lâmina limitante posterior (Descemet) e epitélio posterior $(\text { endotélio })^{195}$.

A segunda túnica do bulbo do olho é a túnica vascular (úvea). Tem três regiões, a saber: a corióde, o corpo ciliar e a íris. As duas últimas situam-se no pólo anterior e a primeira envolve a túnica interna.

A corióde é a porção mais posterior da túnica vascular fornecendo nutrição para as células neurais da retina, de maneira análoga à pia-máter cerebral. Consiste em uma camada esponjosa formada por vasos largos. Distinguem-se da região mais externa para a interna, a supracorióide, o espaço pericorióideo e os vasos sanguíneos da corióide, esta última formada por vasos microscópicos cuja lâmina basal tem contato com a lâmina basal do estrato pigmentoso da retina, com quem forma a membrana de Bruch $^{196}$. Esta membrana tem importante função protetora da retina. No estroma da corióide encontramos fibras de colágeno e inúmeros melanócitos, que podem agrupar-se formando os nevos de corióde ${ }^{197}$.

O corpo ciliar é uma estrutura intermediária entre a corióde e a íris, com as quais, como já visto, forma a úvea anterior. Situa-se próximo à junção entre a córnea e o restante da esclera. Quando seccionado, tem estrutura triangular, dispondo-se em anel $360^{\circ}$ na região de implantação da lente (cristalino), ligando-se firmemente à esclera. Em seu interior aloja-se o músculo ciliar e uma rica rede vascular. O músculo ciliar é inervado pelo III nervo e participa do mecanismo da acomodação ${ }^{198}$, que é responsável pela focalização das imagens próximas ao olho. Esse músculo insere-se na esclera na região de inserção da íris, próximo à transição entre a córnea e o restante da esclera. Os vasos aportam líquido e sais minerais que serão secretados ativamente no humor aquoso, que como já visto, preenche a região anterior do olho, o segmento anterior. Para aumentar a superfície de filtração vascular o corpo ciliar apresenta inúmeras pregas denominadas processos ciliares. O revestimento do corpo ciliar constitui-se de um tecido pigmentado mais interno e um tecido não pigmentado

\footnotetext{
195 American Academy of Ophthalmology, Fundamentals and principles of ophthalmology, p. 42-43.

${ }^{196}$ Eugene WOLFF, Anatomy of the eye and orbit, p. 62.

197 Nevo é uma formação geralmente congênita, proliferativa, que pode ser mais ou menos pigmentada. Sua importância está na possibilidade de malignização que apresenta. Os nevos de corióde são formados pelos melanócitos que estão presentes nessa parte do olho, podendo também, como os da pele, malignizar-se.

${ }_{198} \mathrm{O}$ processo da acomodação ou focalização é o aumento do poder dióptrico do cristalino para focalizar imagens próximas dos olhos, por exemplo, durante a atividade de leitura. Esse complexo mecanismo desenvolve-se por meio da contração do músculo ciliar que relaxa a tensão sobre a cápsula cristaliniana, tensão esta, que mantinha a curvatura anterior do cristalino com raios menores. O aumento da curva anterior do cristalino pode aumentar o poder de focalização da imagem próxima em até $14 \mathrm{D}$, em olhos de crianças. É justamente a perda da capacidade do cristalino aumentar sua curvatura em razão do envelhecimento tecidual que causa a presbiopia, a chamada "vista cansada". Milton KATZ, The human eye as an optical system in Duane's clinical ophthalmology, Vol. 1, cap. 33, p. 49-50.
} 
sobreposto ao primeiro, em contato com as estruturas vasculares do corpo ciliar. A lâmina pigmentada é denominada epitélio retiniano porque é na verdade a continuação do estrato pigmentoso da retina, e estende-se até a margem pupilar (liserée).

A terceira porção da túnica vascular é a íris que é a única visível a olho nu. É a parte colorida do olho. Devido à importância da íris neste estudo, essa estrutura será vista com mais detalhe a seguir.

A túnica interna do bulbo é formada pela retina, pelo nervo óptico e os vasos sanguíneos da retina. Como já dito anteriormente, a retina é a camada sensível à luz. Tem uma estrutura extremamente complexa, e é por sua vez formada por diferentes estratos. Também será vista em separado a seguir.

\subsection{ANATOMIA DA ÍRIS}

A íris é a porção mais anterior e a única porção visível a olho nu da túnica vascular do bulbo do olho. Comumente reconhecida como a parte colorida dos olhos, tem participado do processo de identificação há muito tempo pela facilidade de acesso ao exame desarmado e por sua especificidade pessoal $^{199}$.

A íris faz parte do segmento anterior do olho, delimitando juntamente com a lente (cristalino) a câmara anterior e a posterior. A câmara anterior situa-se entre a córnea e a íris, e câmara posterior situa-se no espaço delimitado pela parte posterior da íris, o corpo ciliar e a lente. Estas câmaras, como já visto anteriormente, são preenchidas pelo humor aquoso, produzido pelo corpo ciliar. Se a córnea é comparável a uma tampa de relógio, a íris é seu mostrador, situando-se paralelamente ao plano sagital da face. Em comparação às outras partes da túnica vascular, portanto, não tem disposição concêntrica em relação à parede do bulbo, mas sim perpendicular a ela.

Constitui-se em um disco delgado com uma abertura central denominada pupila, conhecida popularmente como "menina dos olhos". Essa abertura é de diâmetro variável a depender da luminosidade e da distância focal do objeto fixado pelo olho, funcionando a íris como um diafragma que controla a quantidade de luz que entra no bulbo. Quanto maior a luminosidade, menor o diâmetro pupilar o que acarreta aumento da

\footnotetext{
${ }^{199}$ Hélio GOMES, Medicina legal p. 61.
} 
profundidade de campo ${ }^{200}$. A diminuição do diâmetro pupilar também faz parte do reflexo da acomodação, o que diminui a aberração esférica da imagem focalizada ${ }^{201}$.

A íris insere-se no corpo ciliar em sua porção mais delgada, conhecida como raiz da íris, no ângulo da câmara anterior, região importante por ser o sítio de drenagem do humor aquoso. A margem da pupila está em contato com a cápsula anterior da lente.

A anatomia superficial da face anterior da íris é dividida em duas partes por uma região denominada tradicionalmente como colarete. São elas o anel maior e o anel menor da íris. O colarete é o limite de absorção da membrana pupilar que obstruía a pupila no embrião, e que desaparece por volta do oitavo mês de gestação ${ }^{202}$. O anel menor é conhecido como a zona pupilar da íris e o maior como a zona ciliar da íris.

A íris dos olhos pouco pigmentados permite a visualização das estruturas irianas com mais facilidade. Desde a raiz até a pupila ocorrem os cordões do estroma, alguns vasos e alguns nervos. Estes cordões e vasos têm aspecto sinuoso em "zigzag" permitindo a dilatação ou contração da pupila. O tecido iriano é de natureza conectiva e é denominado estroma. Este tecido é rico em células pigmentares que conferem a cor da íris a depender de variáveis raciais, genéticas e aleatórias. As íris mais pigmentadas têm tecido estromal mais espesso, de natureza mais homogênea e aveludada, ao passo que nos olhos menos pigmentados o estroma é mais ralo, permitindo como já se disse, a visualização dos cordões, vasos e nervos do estroma.

O estroma iriano não é recoberto por um epitélio, sendo que sua superfície irregular apresenta algumas variações de relevo dignas de nota. Há falhas lacunares do estroma que permitem a visualização dos cordões e vasos naquela região denominadas criptas. Sobre as criptas, por vezes visualizam-se pontes de estroma denominadas trabéculas. As criptas podem situar-se tanto na zona ciliar como na pupilar, sendo, porém mais comuns na primeira. Algumas criptas apresentam um revestimento de tecido estromal transparente, donde a denonimação de pseudocriptas ${ }^{203}$. O estroma iriano é bastante frouxo permitindo a

\footnotetext{
${ }^{200}$ A profundidade de campo de visão é o limite de deslocamento espacial entre um objeto e o olho sem que sua imagem perca a nitidez para o observador. Esse limite é influenciado pelo tamanho da pupila da seguinte forma, quanto maior o diâmetro pupilar menor a profundidade de campo, pois a maior difusão da luz dentro do bulbo do olho, permitida por uma pupila maior, ocasiona maior dispersão da imagem na retina, com a conseqüente menor nitidez da mesma. Robert MOSES, Acomodación in Adler's fisiología del ojo, p.285-288.

${ }^{201}$ Eugene WOLFF, Anatomy of the eye and orbit, p. 80.

${ }^{202}$ Ibid., p. 446.

${ }^{203}$ Archimede BUSACCA, Manuel de biomicroscopie oculaire, p. 118.
} 
passagem do humor aquoso por entre suas células. Em algumas íris pigmentadas há estrias radiais na região da zona ciliar, por vezes até na zona pupilar, que representam áreas de espessamento do estroma onde não houve absorção tecidual para a formação das $\operatorname{criptas}^{204}$. Outras alterações no relevo iriano são as dobras de contração criadas pelas ações dos músculos da íris, a serem vistos adiante. Em termos anatômicos, todas essas estruturas são referidas como pregas da íris.

A íris possui dois músculos lisos, o dilatador e o esfíncter da pupila. O primeiro, de inervação simpática ${ }^{205}$, situa-se na face posterior da íris, abaixo do epitélio pigmentado, com o qual se confunde por apresentar também células pigmentadas. Este músculo possui fibras de disposição radial que, ao se contraírem, dilatam a pupila. $\mathrm{O}$ esfíncter tem inervação parassimpática, e situa-se no estroma profundo, próximo à margem pupilar. Suas fibras dispõem-se em círculos ou espirais a partir da pupila, que ao se contraírem, ocasionam seu fechamento. Os dois feixes de fibras musculares encontram-se no anel maior da íris, na zona ciliar ${ }^{206}$. A ação da musculatura iriana ocasiona outras marcas da face anterior da íris, as dobras de contração.

A vascularização da íris forma-se a partir das artérias ciliares posteriores e das artérias ciliares anteriores. Ramos dessas artérias se anastomosam na região do corpo ciliar e formam o círculo maior da íris, a partir do qual os vasos radiais partem no interior do estroma iriano. Na região da pupila há algumas anastomoses incompletas o que leva alguns autores a descrever nessa região o círculo menor da íris ${ }^{207}$.

Os nervos irianos correm juntamente com os vasos ao longo dos cordões da íris. São derivados dos nervos ciliares longos e $\operatorname{curtos}^{208}$.

Em corte sagital, a íris apresenta quatro camadas, da face anterior para a posterior: a camada limitante anterior, ou de Henle, o estroma, a membrana posterior e o epitélio pigmentado. A camada limitante anterior ou de Henle não possui uma camada celular pavimentosa, sendo simplesmente uma obliteração do tecido conectivo do estroma da íris. É essa camada a principal responsável pela coloração iriana porque a maior ou menor presença de melanócitos ou de tecido em sua composição irão determinar a tonalidade da cor

\footnotetext{
${ }^{204}$ Archimede BUSACCA, Manuel de biomicroscopie oculaire, p. 118-119.

205 In vitro pode-se demonstrar uma dupla inervação tanto para o dilatador quanto para o esfíncter da pupila American Academy of Ophthalmology, Fundamentals and principles of ophthalmology, p. 51.

${ }^{206}$ Eugene WOLFF, Anatomy of the eye and orbit, p. 87.

207 Ibid. p.85-86.

${ }^{208}$ Ibid., p.86.
} 
dos olhos ${ }^{209}$. O estroma é formado de fibras colágenas, matriz de mucopolissacarídeos, melanócitos e células não pigmentadas ${ }^{210}$. No interior do estroma encontram-se os vasos que formam a porção de sustentação do tecido e nervos, além do músculo esfíncter da pupila. A membrana posterior, também chamada de epitélio anterior ${ }^{211}$, apresenta alguns grânulos de pigmentação e fibras musculares que formam o dilatador da pupila. A camada mais interna é o epitélio pigmentado (ou retiniano) que apresenta intensa pigmentação e é contínuo com o epitélio pigmentar da retina. Esta camada estende-se até a pupila formando uma borda rendilhada ou denteada nessa região denominada liséré $e^{212}$.

A face posterior da íris apresenta pregas radiais denominadas dobras radiais de Schwalbe, além de outras dobras circulares menos proeminentes ${ }^{213}$.

A cor da íris, como já mencionado, depende de diversos fatores. De início, os bebês de pele clara não têm, em suas íris, pigmentos suficientes para determinar uma cor definida, tendo em geral, olhos azulados, devido a um efeito semelhante à coloração azulada dos vasos sangüíneos visualizados sob a pele clara ${ }^{214}$. Com o crescimento, ocorre a migração das células pigmentares até o estroma, determinando a maior ou menor intensidade de sua cor. Os bebês de pele escura, por sua vez, já têm desde o nascimento células pigmentadas em suas íris, o que determina a coloração escura de seus olhos desde a mais tenra idade. Também nesses indivíduos, o número de células pigmentadas aumenta com o crescimento. A cor predominante final depende da quantidade de tecido e pigmento presentes, sendo que os olhos mais claros, os azuis, quase não apresentam pigmentação no estroma. Têm, portanto, a cor azulada devido à combinação do efeito dos cordões esbranquiçados vasculares do estroma e do epitélio pigmentar posterior. Embora a determinação da cor da íris seja em parte genética, o resultado final do fenótipo depende de muitos fatores, não podendo ser prevista de maneira simplista. Em geral, as íris claras têm herança genética recessiva.

A topografia da íris, porém, não apresenta determinação genética, sendo rigorosamente diferente de olho para olho, no mesmo indivíduo e nos olhos dos gêmeos idênticos.

\footnotetext{
${ }^{209}$ Eugene WOLFF, Anatomy of the eye and orbit, p.84.

${ }^{210}$ American Academy of Ophthalmology, Fundamentals and principles of ophthalmology, p. 50.

${ }^{211}$ Nome criticado por alguns, ver Eugene WOLFF, Anatomy of the eye and orbit, p. 87.

${ }^{212}$ Archimede BUSACCA, Manuel de biomicroscopie oculaire, p. 122.

${ }^{213}$ Eugene WOLFF, Anatomy of the eye and orbit, p. 82.

${ }^{214}$ Ibid., p. 89.
} 
A íris pode sofrer efeitos do envelhecimento. A margem pupilar perde sua pigmentação apresentando então uma coloração esbranquiçada, denominada degeneração hialina da margem pupilar. A porção pupilar também se atrofia, levando ao surgimento de um degrau mais evidente entre o tecido ao redor da pupila e o restante da íris (pupila em cratera). Nessa região atrófica pode surgir uma dispersão ou diminuição pigmentar chamada de dispersão pigmentar de $\operatorname{Vogt}^{215}$.

Algumas condições clínicas também alteram a superfície da íris. O glaucoma de ângulo estreito evolui em crises de hipertensão ocular que acarretam lesões à face anterior da íris, distorcendo sua superfície. Também o glaucoma neovascular pode alterar a anatomia original da íris por induzir o crescimento de vasos sobre a mesma. Alterações inflamatórias irianas, as iridociclites, podem acarretar aderências entre a íris e as demais paredes da câmara anterior modificando seu relevo. Também essas reações inflamatórias podem descolorir a íris, como na Iridoclite heterocrômica de FUCHS. Há raros quadros de atrofia iriana progressiva idiopática que alteram a face anterior da íris de forma intensa. Medicamentos podem alterar a cor dos olhos aumentando sua pigmentação como a Pilocarpina e os derivados de prostaglandinas, ambos, medicamentos antiglaucomatosos ${ }^{216}$.

Essas possíveis mudanças da face anterior da íris são fatores de imprecisão da biometria iriana, o que não pode ser esquecido na avaliação desse método de identificação.

\subsection{ANATOMIA DA RETINA}

A retina é a túnica mais interna do globo ocular, sendo formada pelas células sensíveis à luz, os fotorreceptores, as células neurais que participam na transmissão do estímulo visual e a neuroglia retiniana, que dá suporte nutricional e estrutural às outras células. Comparando-se o olho a uma câmara fotográfica, a retina corresponderia ao filme fotográfico, ou ao CCD de uma câmara digital ${ }^{217}$.

Como já foi dito anteriormente, a parte central da retina situa-se no pólo posterior, região oposta à porção frontal do bulbo do olho, o segmento anterior. No pólo posterior visualizamos o disco do nervo óptico, a mácula (ponto central de fixação do olhar que é a porção mais sensível à luz da retina) e os vasos arteriais e venosos que se distribuem a

\footnotetext{
215 Archimede BUSACCA, Manuel de biomicroscopie oculaire, p. 125-126.

${ }^{216}$ Debora PAVAN-LANGSTON, Manual of ocular diagnosis and therapy, p.246, 259-262.

217 "Charge coupled device", dispositivo que transforma a energia luminosa em sinais elétricos para serem posteriormente transferidos para outra forma de registro, seja informático, seja impresso.
} 
partir da papila. A retina estende-se do pólo posterior até a região do corpo ciliar, terminando em uma região denominada ora serrata.

A retina divide-se em duas camadas: a retina neurossensorial e o epitélio pigmentar retiniano ${ }^{218}$. A retina neurossensorial é uma fina camada translúcida que tem na sua maior espessura $0,5 \mathrm{~mm}$ (no disco óptico). O epitélio pigmentado situa-se mais próximo à parede do globo ocular, situando-se em estreita relação com a corióide, a camada vascular do olho (ver acima). Essas duas camadas estão firmemente ligadas apenas ao redor do nervo óptico e próximo ao corpo ciliar. Todas as outras áreas estão em aposição e mantêmse no local pela ação da pressão do gel ocular, o humor vítreo, da função metabólica das células em contacto das duas camadas e pela matriz celular entre elas ${ }^{219}$.

A retina neurossensorial é formada por células de três tipos, as neuronais, as gliais e as vasculares ${ }^{220}$. Estas células estão distribuídas topograficamente em dez estratos distinguíveis histologicamente ${ }^{221}$. As células neuronais são os fotorreceptores, as células horizontais, as células bipolares e as celulares ganglionares. As células gliais mais importantes são as de Muller. As vasculares formam os vasos retinianos que se situam nas camadas mais internas da retina ${ }^{222}$.

Os fotorreceptores são células sensíveis à luz de dois tipos, os cones (sensíveis à cor e à luminosidade maior) e os bastonetes (sensíveis à baixa luminosidade). Esses nomes advêm da forma de cada tipo celular. Estas células são responsáveis pela transformação do estímulo luminoso em impulso nervoso a ser transmitido ao cérebro pelo nervo óptico. Tal processo envolve complexas reações eletro-químicas que são realizadas com a utilização de pigmentos fotossensíveis produzidos por essas células. A distribuição dessas células da retina não é homogênea. Na mácula, onde como já foi visto, ocorre a fixação ocular, há um predomínio de cones. Na periferia, há um predomínio de bastonetes que permitem a visão em condições de menor luminosidade. A transmissão do impulso visual é realizada com a participação das demais células neurais, a saber, as horizontais, as bipolares e as ganglionares, que se distribuem pelas camadas da retina. $\mathrm{O}$

\footnotetext{
218 James L. FEDERMAN et al., Retina and Vitreous in Textbook of ophthalmology, Part 2 Anatomy, passim.

219 Ibid, passim.

${ }^{220}$ American Academy of Ophthalmology, Fundamentals and principles of ophthalmology, p. 56-57.

221 Essas camadas são, de fora para dentro do bulbo do olho, o epitélio pigmentar, a camada dos cones e bastonetes, a membrana limitante externa, a camada nuclear externa, a camada plexiforme externa, a camada nuclear interna, a camada plexiforme interna, a camada ganglionar, a camada de fibras nervosas e a membrana limitante interna. Stephen J. RAY ed., Retina, vol. 1, cap. 4, passim.

${ }^{222}$ American Academy of Ophthalmology, Fundamentals and principles of ophthalmology, p. 56-57
} 
mecanismo de transmissão é extremamente complexo e ainda não totalmente compreendido $^{223}$.

As células gliais de Muller formam estruturalmente as camadas da retina, fornecendo suporte e nutrição para os elementos neurais da retina, da mesma forma que a glia do sistema nervoso central ${ }^{224}$. Sua membrana celular forma as camadas limitantes interna, que separa a retina do vítreo, e externa, que ancora os fotorreceptores em sua $\operatorname{posição~}^{225}$.

Os elementos vasculares da retina são formados por ramos da artéria e veia centrais da retina, que se dispõem mais superficialmente na porção interior da mesma. Estes vasos são responsáveis pela nutrição das camadas retinianas mais internas. A nutrição das camadas mais externas da retina (as mais próximas da parede do olho) é realizada pela circulação da corióide.

Esses vasos entram no globo ocular junto com o nervo óptico, sendo bem visíveis na papila, que é a estrutura inicial do nervo. A partir da papila os vasos saem e deixam o globo em trajetos radiais, que são os mais variados possíveis, sendo que a disposição dos mesmos é única para cada olho e absolutamente aleatória de indivíduo para indivíduo. Além disso, o aspecto dessa vascularização é constante ao longo da vida o que permite sua utilização como método de identificação biométrica como será visto adiante.

O epitélio pigmentado envolve os fotorreceptores auxiliando em sua função por meio da eliminação dos restos do metabolismo do mecanismo da visão. Além disso, ajuda no suporte dessas estruturas. Suas células são formadas por diversas estruturas especializadas tanto na eliminação dos metabólitos quanto na manutenção da quantidade de líquido na retina, por isso são polarizadas. Exercem também um efeito de barreira à passagem de substâncias plasmáticas da corióide para a retina, por meio de sua membrana basal. Esta faz parte da membrana de Bruch, que é formada também por substâncias colágenas e elásticas e da membrana basal dos vasos da corióide.

Este epitélio é assim chamado porque suas células têm pigmento, localizados em estruturas denominadas melanossomos ${ }^{226}$. O pigmento participa do mecanismo de absorção da luz e troca de calor. Trata-se de epitélio não é homogêneo em

\footnotetext{
${ }^{223}$ Adolph I.COHEN, Retina y nervio óptico in Adler's fisiología del ojo, p. 348-384.

${ }^{224}$ Ibid., p. 57.

${ }^{225}$ Eugene WOLFF, Anatomy of the eye and orbit, p.118-119.

${ }^{226}$ Ibid.,p. 55.
} 
todas as áreas retinianas, variando suas estruturas com a especialização da retina. Anatomicamente tem continuidade com o epitélio pigmentado do corpo ciliar e da íris, embora seja muito menos pigmentado que os epitélios uveais. Por apresentar pigmentos de mais de um tipo, contribui, juntamente com a corióide, para a formação da cor observada durante o exame da retina.

A cor das estruturas retinianas depende da quantidade de pigmento do epitélio pigmentado e da corióide, da quantidade de sangue na corióide bem como da disposição de seus vasos, e do tipo e intensidade da luz empregada em sua visualização ${ }^{227}$.

$\mathrm{O}$ aspecto anatômico da retina sofre alterações ao longo da vida. No recém-nascido, a retina é menos pigmentada adquirindo a coloração igual à do adulto nos primeiros anos de vida. As alterações vasculares relacionadas à idade e a doenças circulatórias alteram a coloração do fundo do olho e o aspecto e a posição dos vasos retinianos, o que, sem dúvida, contribui para a mudança do aspecto global da retina ao longo do tempo. Tais mudanças têm de ser levadas em consideração nas análises seriadas da imagem retiniana, eis que são fatores de imprecisão do método.

Descritas as bases biológicas para a biometria ocular, passa-se à análise de suas bases tecnológicas.

${ }^{227}$ Arno NOVER, O fundo de olho, p.39. 


\section{CAPÍTULO IV. BASES TECNOLÓGICAS PARA A BIOMETRIA OCULAR}

\subsection{OBTENÇÃO E PROCESSAMENTO DA IMAGEM DAS ESTRUTURAS OCULARES PARA FINS BIOMÉTRICOS}

A biometria das estruturas oculares é realizada por meio da utilização de imagens da íris ou da retina captadas por uma câmera digital. Uma vez captada, a imagem é processada digitalmente pela câmera e transformada por um algoritmo em um modelo ("template") que será armazenado em um banco de dados informático.

A captação da imagem ocorre em dois momentos distintos: no registro inicial da imagem para o banco de dados ("enrollment") e no momento em que alguém se apresenta ao sistema para ter sua identidade verificada ou autenticada ("matching"). A câmera que capta essas imagens deve ter sensibilidade suficiente para a obtenção de uma de imagem com a definição que o método exige.

O software específico do método também é utilizado nesses dois momentos e deve rapidamente converter as imagens digitalizadas por meio do algoritmo próprio, criptografar e armazenar os dados no banco de dados do sistema. Na segunda fase, que é a da validação ou reconhecimento, o algoritmo também desenvolve uma comparação entre o modelo apresentado e o arquivado, estabelecendo ou não a correspondência entre eles.

A fase de reconhecimento ("matching") pode ser feita sem utilizarse um banco de dados. Para isso, é necessário que aquele que se apresenta para identificação possua um dispositivo de memória que registre os dados digitais de sua estrutura ocular processados pelo mesmo algoritmo. Assim, o sistema terá a capacidade de confirmar a correspondência da estrutura ocular analisada com os dados contidos no registro apresentado.

A biometria ocular utiliza câmeras digitais. Esses aparelhos funcionam com um sistema óptico semelhante a uma câmera convencional, ou seja, possuem lentes e diafragma com diâmetros e velocidades de abertura ajustáveis para maximizar a qualidade da imagem a ser registrada. As diferenças entre os dois tipos de câmeras estão nos sistemas de captura e armazenamento dessa imagem.

A câmera convencional registra a imagem em um filme fotográfico, que é uma película recoberta de compostos de prata fotossensíveis. Uma vez que a luz incida 
sobre esse filme, reações químicas são desencadeadas e compostos de prata em emulsão em diferentes camadas registram a luminosidade, a cor e os contornos da imagem fotografada. Após esta fase, o filme deve ser processado para transferir a imagem inicial para um papel apropriado, processo chamado de revelação e ampliação fotográficas.

Uma câmera digital captura a imagem por meio de um dispositivo denominado "dispositivo de carga acoplado" ("charge coupled device" CCD) e a armazena e processa digitalmente. Os sensores CCD registram a cor por meio de filtros, que podem ser comparados às diversas camadas de emulsão de um filme fotográfico. Esse processo desenvolve-se em etapas.

Inicialmente, a exposição à luz é convertida em carga elétrica por meio de fotodiodos. Fotodiodos são elementos microeletrônicos compostos por materiais semicondutores que alteram sua condutividade elétrica ou geram uma corrente ao serem atingidos por energia luminosa. Materiais semicondutores apresentam condutividade elétrica variável de acordo com as condições a que estão submetidos, como a temperatura, o potencial elétrico do sistema e no caso dos fotodiodos, a quantidade de energia luminosa que recebem.

Atualmente, a quase totalidade dos semicondutores é fabricada com silício (no passado foi também utilizado o germânio). Esses elementos não conduzem a energia elétrica em seu estado natural, não são, portanto, condutores, pois apresentam uma estrutura cristalizada sem elétrons livres. Para que se transformem em semicondutores, o Silício e o Germânio são misturados a pequenas quantidades de outros elementos que alteram essa estrutura estável (processo denominado dopagem). Acrescentando-se boro ou índio ao silício, obtêm-se um cristal receptor de elétrons, denominado cristal P (de positivo). Acrescentando-se fósforo obtêm-se um cristal doador de elétrons, denominado cristal $\mathrm{N}$ $(\text { negativo })^{228}$. Esses dois tipos de cristais estão combinados no fotodiodo do CCD para que quando a energia luminosa o atinja, sua condutividade se altere e a corrente elétrica passe por ele.

A disposição de milhares desses fotodiodos permite que os fenômenos elétricos surgidos em cada um deles sejam traduzidos pelo processador da câmera

\footnotetext{
${ }^{228}$ O boro e o índio combinam-se com os átomos de silício ou germânio criando espaços sem elétrons na estrutura atômica denominados lacunas enquanto o fósforo ao combinar-se, gera um elétron excedente. A combinação de cristais com lacunas e elétrons pode criar uma corrente. Esse é, grosso modo, o princípio do diodo semicondutor, do qual o fotodiodo é espécie.
} 
em uma informação digital na linguagem binária 1 ou 0 (bits e bytes ${ }^{229}$ ). A informação armazenada é sobre a cor daquele ponto da imagem, sua luminosidade, brilho e etc. O menor ponto de uma imagem captada por fotodiodos e digitalizada é denominado pixel. Pixel é um neologismo formado pelas palavras inglesas "Picture" (pix) "Element" (el), e pode ser traduzido como elemento de imagem. Quanto mais pontos de imagens uma câmera conseguir captar e processar, maior a nitidez da imagem resultante. Na prática, cada pixel da imagem é formado por fotodiodos que respondem a diferentes cores, ou comprimentos de onda de luz.

A transformação da imagem em linguagem digital permite que ela seja armazenada em um disco rígido, em um cartão de memória, ou um dispositivo de mídia como um CD ou um "pen-drive". Também permite que essa informação digitalizada seja transmitida pela Internet ou por um cabo de TV ou mesmo por ondas eletromagnéticas. É possível também que programas de computador processem a imagem digitalizada modificando-a.

Decodificada em linguagem informática, a imagem digitalizada da estrutura ocular obtida na biometria é processada por um programa específico do método com diversos algoritmos. Esses algoritmos processarão a análise da qualidade dos dados obtidos e o armazenamento da combinação única de caracteres que permitirá a identificação posterior do indivíduo. Essa combinação é o modelo ("template") específico da estrutura orgânica avaliada pelo método biométrico. Quanto mais simples esse modelo, ou seja, quantos menos bytes ele contiver, maior a rapidez do seu processamento informático.

Por exemplo, os modelos biométricos da íris têm 512 bytes. Esse número, que é considerado pequeno, permite grande velocidade de processamento da informação pelos computadores do sistema. A verificação de um indivíduo leva apenas dois segundos. Em um processador de $300 \mathrm{MHz}, 100.000$ íris são analisadas por segundo; em um de $2.2 \mathrm{Ghz}$, um milhão em 1,7 segundo $^{230}$.

O uso de computadores para armazenamento e processamento das informações é, portanto, essencial à biometria das estruturas oculares como a qualquer outra

\footnotetext{
229 "Bit" vem da expressão inglesa "binary digit". Bytes são grupos de 8 bits, utilizados para aumentar a capacidade de armazenamento de informações.

${ }^{230}$ John R. VACCA, Biometric technologies and verification systems, p. 75.
} 
modalidade biométrica. No caso da biometria da íris, a velocidade do processador é a principal limitação de desempenho do método ${ }^{231}$.

\subsection{ANÁLISE INFORMÁTICA DOS DADOS BIOMÉTRICOS OCULARES}

A biometria das estruturas oculares só se tornou possível após o desenvolvimento de modelos estatísticos e matemáticos para o processamento informatizado das características oculares. O processamento informático dos dados biométricos é a base da operacionalidade, confiabilidade e sensibilidade desses métodos, razão pela qual, a história dos softwares e algoritmos confunde-se com a própria história da biometria ocular ${ }^{232}$. A total compreensão do tema por sua complexidade escapa ao objetivo desse texto, mas serão analisados alguns aspectos desses componentes biométricos oculares.

A biometria da íris tornou-se factível pelo desenvolvimento do método matemático de processamento das imagens da íris por John Daugman, físico e especialista em visão computacional ${ }^{233}$, ex-professor de Harvard hoje em Cambridge. Seu algoritmo é utilizado pela maior parte dos sistemas de reconhecimento de íris em operação, sendo que a patente do mesmo é da Iridian Technology Inc. Algumas das empresas que incorporam esses algoritmos em seus sistemas são as acima elencadas LG, a MatsushitaPanasonic, IrisGuard e a SecuriMetrics ${ }^{234}$. Segundo o próprio inventor, entretanto, novos algoritmos estão atualmente em desenvolvimento em diversos centros e empresas ${ }^{235}$.

Os algoritmos desenvolvidos por Daugman são algoritmos de processamento de imagem. A imagem captada por meio de câmeras que utilizam luz infravermelha é inicialmente submetida a um processo chamado de segmentação. O objetivo da segmentação é delinear a íris e a pupila e mapear as porções da íris encobertas pelas pálpebras e cílios ou borradas por reflexos causados por óculos ou lentes. A segmentação é realizada por um método de estimativa de borda circular (“circular boundary estimation").

\footnotetext{
${ }^{231}$ LG Electronics U.S.A., "Iris recognition".

${ }^{232}$ James R. MATEY et al. , Iris recognition in less constrained environments in Advances in biometrics, p. $111 \mathrm{e}$ 112.

233 Visão computacional (Visão por computador) é a área da ciência que se dedica a desenvolver teorias e métodos voltados à extração automática de informações úteis contidas em imagens. Tais imagens são capturadas por dispositivos eletrônicos de captação de imagem, como câmera de vídeo, scanner, etc. Departamento de Informática da Universidade Estadual de Maringá http://www.din.uem.br acesso em 4 de janeiro de 2007.

${ }^{234}$ John DAUGMAN. How iris recognition works. p. 1.

${ }^{235}$ Ibid., p.73 e 74.
} 
Algoritmos de estimativa de borda são fórmulas matemáticas que analisam imagens digitalizadas isolando determinados componentes das mesmas. Como as imagens da íris apresentam bordas circulares, a fórmula matemática utilizada por Daugman nessa fase foi uma série equações discretas de Fourrier ${ }^{236}$.

Após esta fase, a imagem passa por um processo chamado normalização. A normalização desdobra as informações da imagem iriana em arco para uma forma em faixa, através de um processo pseudopolar de coordenadas que mapeiam a íris em unidades radiais de 0 a $2 \pi$. Essa transformação leva em conta irregularidades da pupila, podendo, no entanto, apresentar distorções por mudanças destas variáveis ${ }^{237}$.

O próximo passo é a codificação propriamente dita, que utiliza um algoritmo de onduletas de Gabor que processam os dados da imagem em 128 posições em ângulo e 8 posições em rádios com dois bits em cada posição. Para superar problemas de não confiabilidade desses pontos, um segundo cálculo é realizado para os mesmos. A soma do total desses bits que é 4096 bits ou 512 bytes. Posteriormente, este modelo pode ser submetido a um sistema de criptografia para que os dados fiquem menos vulneráveis à manipulação por terceiros ${ }^{238}$.

A comparação entre o modelo obtido no momento da identificação e o armazenado ("matching") é realizada pelo método estatístico "distância de Hamming", que compara os dois modelos e estabelece uma relação entre o número de diferenças entre eles e o número de comparações realizadas. Se este relação for menor que 0,33 a probabilidade das íris serem as mesmas é muito grande e a autenticidade ou a identidade pode ser estabelecida ${ }^{239}$.

Os primeiros equipamentos para biometria retiniana não processavam propriamente imagens da retina, mas sim reflexos gerados pelos tecidos do fundo de olho, a retina e a corióide ${ }^{240}$. Foram as dificuldades técnicas envolvidas na obtenção das imagens que levaram Hill e seus associados a optarem por submeter os reflexos retinianos e não as imagens do fundo de olho a algoritmos geradores de modelos biométricos. Mas, além

\footnotetext{
${ }^{236}$ James R. MATEY et al, Iris recognition in less constrained environments in Advances in Biometrics, p. 113.

${ }^{237}$ David USHER, Yasunari TOSA e Marc FRIEDMAN, Ocular biometrics: simultaneous capture and analysis of the retina and iris in Advances in biometrics, p. 141.

${ }^{238}$ Ibid., p. 113 e 114. Essas expressões matemáticas são de grande complexidade para leigos, mas comumente utilizadas em visão computacional.

${ }^{239}$ David USHER, Yasunari TOSA e Marc FRIEDMAN, Ocular biometrics: simultaneous capture and analysis of the retina and iris in Advances in biometrics, p. 114.

${ }^{240}$ Robert B. HILL, Retina identification in Biometrics personal identification in networked society, p. 123-142.
} 
disso, a análise dos reflexos elimina a necessidade de um sistema de focalização mais preciso prevenindo diferenças causadas por problemas refracionais dos olhos examinados nas imagens obtidas $^{241}$.

Esse reflexo gera um sinal unidimensional de uma região circular ao redor da mácula. O sistema correlaciona informações de contraste de duas formas: uma no domínio freqüência e outra no domínio tempo por meio de um tipo de transformada discreta de Fourier (FFT ou fast Fourier transforms). O modelo biométrico resultante apresenta grande simplicidade tendo apenas 48 bytes $^{242}$.

Para a comparação entre um modelo a ser validado/identificado e um armazenado no arquivo, inicialmente equalizam-se os dois modelos e após esta etapa, é feita a comparação entre eles com transformadas de Fourier no domínio tempo. Correlações acima de 0,7 são consideradas indicativas de identidade entre as amostras comparadas ${ }^{243}$.

O novo sistema de biometria retiniana que está sendo apresentado pela companhia Retica Incoporated utiliza outros parâmetros. Os caracteres biométricos desse novo método são os vasos sanguíneos retinianos ao redor do disco óptico. Sua aquisição é feita por meio de uma imagem retiniana obtida por novas câmeras de procedimentos médicos oftalmológicos avançados. A luz utilizada está na faixa do infravermelho e não causa perturbação ou dano ao usuário. A imagem será processada para: 1- reconhecer esses vasos, 2- seguir seu trajeto e 3-gerar por meio do algoritmo do método um modelo biométrico capaz de atender as exigências de identificação. Essas etapas são evidentemente realizadas por procedimentos de processamento de imagens de visão computacional semelhantes aos descritos para a biometria da íris. Esse novo sistema foi especialmente desenvolvido para ser realizado em combinação com a biometria da íris, provendo assim o primeiro método multibiométrico multimodal exclusivamente baseado em traços biométricos oculares. Os algoritmos utilizados para a biometria da íris também foram desenvolvidos pela companhia. Não é possível conhecer ainda esses algoritmos, bem como os retinianos por questões comerciais relacionadas às patentes do método ${ }^{244}$.

\footnotetext{
${ }^{241}$ Os erros de refração, a saber, miopia, hipermetropia e astigmatismo causam distorções nas imagens das estruturas do fundo de olho, independentemente do sistema de imagem utilizado. Ver Debora PAVANLANGSTON, Manual of ocular diagnosis and therapeutics. Capítulo 14.

${ }^{242}$ Robert B. HILL, Retina identification in Biometrics persona identification in networked society, p. 128.

${ }^{243}$ Ibid., p. 134.

${ }^{244}$ David USHER, Yasunari TOSA e Marc FRIEDMAN, Ocular biometrics: simultaneous capture and analysis of the retina and iris in Advances in biometrics p. 133-155.
} 
Os procedimentos informáticos da biometria ocular utilizam-se também de grandes sistemas operacionais como o Windows ${ }^{\circledR}$ e outros, permitindo a compartilhamento das informações e das operações entre sistemas distintos. 


\section{CAPÍTULO V. OPERACIONALIZAÇÃO DA BIOMETRIA OCULAR}

\subsection{TIPOS DE BIOMETRIA OCULAR}

As duas técnicas de biometria de estruturas oculares são a biometria da íris e a biometria da retina. Ambas representam evoluções de propostas mais antigas de identificação que não puderam ser desenvolvidas na época de sua descoberta.

\subsubsection{Biometria da íris}

A íris sempre chamou atenção do homem por sua coloração variada e pela sua conformação única. Antigas civilizações acreditavam poder descobrir informações sobre os indivíduos pela análise de suas íris, prática que permanece até hoje com o nome de iridologia. A primeira referência científica de identificação por características da íris vem do sistema de Bertillon, citado acima, que incluiu em seu método a observação e anotação das características da íris esquerda dos indivíduos ${ }^{245}$.

Em 1949 o oftalmologista britânico James Doggart sugeriu que as características variadas da íris poderiam ser suficientemente exclusivas para serem usadas na identificação humana. Em 1987, dois oftalmologistas americanos, Flom e Safir conseguiram patentear $\mathrm{O}$ conceito de identificação pela íris, embora não constasse da patente nenhum método efetivo para realizar essa identificação. Em 1989, esses oftalmologistas propuseram a John Dougman, professor de visão computacional em Harvard, que criasse um método para realizar essa identificação, o que foi efetivamente desenvolvido por ele. Dougman é, por isso, considerado o inventor da identificação pela íris. Após percalços comerciais, o método alcançou um patamar de custos e operacionabilidade tal que viabilizou sua utilização em maior escala ${ }^{246}$.

O padrão de variação da superfície iriana é muito grande por que sua estrutura é formada, como já visto, por muitas camadas e porque sua embriogênese obedece a um padrão aleatório. Estima-se que a variabilidade de padrões irianos é da ordem de 10 elevado a $78^{247}$. É por isso que uma íris nunca é igual a outra, mesmo que ambas sejam do mesmo indivíduo.

\footnotetext{
${ }^{245}$ Ver item 2.3 supra, p. 37. John DAUGMAN, Iris recognition, in Handbook of Biometrics, p. 72.

246 John R. VACCA, Biometrics technologies and verification systems, p. 74, John DAUGMAN, Iris Recognition, in Handbook of biometrics, p. 72 e 73.

${ }^{247} \mathrm{http}: / /$ www.lgiris.com acesso em 9 de janeiro de 2008.
} 
A biometria da íris apresenta as seguintes vantagens:

- a íris tem estrutura estável ao longo da vida, protegida dentro de um órgão sem contato com o mundo externo;

-é um método de identificação eficiente, isoladamente ou em combinação com outros sistemas biométricos;

- apresenta um baixo número de falhas no registro inicial (FTER faillure to enroll rate), 7 \%, seja pela facilidade na obtenção do registro, seja pela quase universalidade da presença da íris em pelo menos um dos olhos;

- é um método rápido;

- apresenta um padrão biométrico confiável por ser dificilmente fraudável;

- é um método não invasivo;

- apresenta baixas taxas de falsa rejeição (FNMR) 2,5 \% e falsa aceitação (FMR) $<0,0001 \%$. Sua taxa de "equal error" é igual a 1 em 1,2 milhão;

- é o método mais adequado para identificação “1-n” atualmente em operação;

As desvantagens, por outro lado, são seu custo relativamente elevado e sua taxa de não-aceitação por alguns usuários ${ }^{248}$.

\subsection{2.- Biometria da retina}

A biometria retiniana também tem antecedentes históricos. Levinsohn apresentou um método de identificação pelas estruturas únicas do fundo de olho registradas em fotografias que não tinha, à época, possibilidades técnicas de ser aplicado em larga escala ${ }^{249}$. Em 1935, Simons e Goldenstein chamaram a atenção para o caráter único do padrão vascular de cada olho. Nos anos 50, Tower estudou as retinas de gêmeos idênticos demonstrando a unicidade de seus padrões vasculares retinianos, considerando inclusive que, entre todos os parâmetros, este era o menos semelhante entre gêmeos. Em 1975, Robert B. Hill, retomando os conceitos de Simons, Goldenstein e Tower, estudou um método biométrico de identificação pelos vasos retinianos, utilizando inicialmente equipamento oftalmológico clínico. Posteriormente, o método foi aperfeiçoado com a utilização de equipamentos mais

\footnotetext{
${ }^{248}$ John R. VACCA, Biometric technologies and verification systems, p. 79 a 81 e 450.

${ }^{249}$ Eduardo R.A. DEL-CAMPO, Medicina legal, p. 58. Ver item 3.2 acima.
} 
aceitáveis por parte do usuário, e colocou-se no mercado. Problemas técnicos e comerciais têm limitado a ampliação do uso dessa técnica. Recentemente, novas empresas retomaram a biometria retiniana com a utilização de novas tecnologias, inclusive em combinação com a biometria da íris ${ }^{250}$.

A exclusividade de cada padrão vascular retiniano é garantida pelo alto grau de aleatoriedade envolvido no processo de vasculogênese embrionária ${ }^{251}$. Esse padrão é muito estável ao longo da vida, alterando-se, no entanto, em casos de graves retinopatias vasculares (por exemplo, retinopatia diabética avançada, oclusões venosas e etc.).

A biometria da retina apresenta as seguintes vantagens:

- é o mais exclusivo caractere biométrico, com taxas de falsa rejeição e positivação próximas a zero;

- não pode ser fraudado por estrutura sem-vida;

- apresenta modelo biométrico de pequenas dimensões facilitando sua informatização;

- é estrutura estável e protegida por ser interna;

As desvantagens são as seguintes:

- percepção de ameaça à saúde por parte do usuário (que é falsa);

- requer escaneamento a pequenas distâncias;

- requer grande cooperação por parte do usuário;

- lentes de contato e óculos podem atrapalhar a captação do traço biométrico;

- Custo muito elevado ${ }^{252}$.

Essas desvantagens dificultam a implementação da biometria retiniana na prática, sendo que só se conhece sua utilização por sistemas com alto nível de segurança, como por exemplos, recursos militares. Os novos equipamentos de biometria

${ }^{250}$ Robert B. HILL, Retina identification in Biometrics personal identification in networked society, p. 124. John R. VACCA Biometrics technologies and verification systems, p. 87 e 88, David USHER, Yasunari TOSA e Marc FRIEDMAN, Ocular biometrics: simultaneous capture and analysis of the retina and iris in Advances in biometrics p. $133-153$.

${ }^{251}$ David USHER, Yasunari TOSA e Marc FRIEDMAN, Ocular biometrics: simultaneous capture and analysis of the retina and iris in Advances in biometrics p. 137.

${ }^{252}$ John R. VACCA, Biometric technologies and verifications systems, p. 90 e 91. 
retiniana utilizam-se de novas tecnologias de captação de imagem médicas e prometem contornar algumas dessas desvantagens ${ }^{253}$.

Comparando-se as duas técnicas de biometria ocular, podem-se apontar, no momento, as vantagens do sistema de biometria da íris em todos os aspectos em relação à biometria retiniana, o que explica sua maior presença no mercado. Realmente, é o sistema de identificação pela íris que tem sido utilizado, isoladamente ou em combinação com outros métodos de identificação ou autenticação, em diversos aeroportos e fronteiras no controle de imigração, no controle de acesso físico a determinadas instalações, na autenticação de identidade em caixas eletrônicos ("ATMs"), como meio de controle de uso de aparelhos como celulares, como forma de autenticação de beneficiários a recursos governamentais, como controle da presença física de apenados em sistemas prisionais, como controle de acesso em escolas e universidades, entre outros ${ }^{254}$.

Analisam-se, a seguir alguns equipamentos hoje disponíveis para a realização das técnicas biométricas oculares.

\subsection{EQUIPAMENTOS UTILIZADOS NA BIOMETRIA OCULAR}

As câmeras digitais e os computadores utilizados na biometria ocular devem preencher os requisitos padrões do sistema.

Na biometria da íris, as câmeras podem ser monocromáticas já que iferenças em tons de cinza na imagem são suficientes para seu processamento pelo algoritmo específico. Este processo requer uma imagem de 70 a 140 pixels. A maior parte dos sistemas, porém, utiliza uma câmera digital monocromática de 480 x 640 pixels de resolução (equivalente a uma câmera fotográfica de 0,3 megapixels), porque a iluminação de trabalho do sistema é a NIR (700 a 900 nm), ou seja, a operação dessas câmeras realiza-se com luz infravermelha, inofensiva ao olho humano, segundo normas da ANSI $^{255}$.

\footnotetext{
253 David USHER, Yasunari TOSA e Marc FRIEDMAN, Ocular biometrics: simultaneous capture and analysis of the retina and iris in Advances in biometrics p. 133 - 153.

${ }^{254}$ John DAUGMAN, Iris recognition, in Handbook of biometrics, p. 71 e 72. John R. VACCA Biometrics technologies and verification systems, p. 81 e 82.

${ }^{255}$ DAUGMAN, John. How iris recognition works. p. 2, David USHER, Yasunari TOSA e Marc FRIEDMAN, Ocular biometrics: simultaneous capture and analysis of the retina and iris in Advances in biometrics, p. 143. NIR é a faixa de onda infravermelha mais próxima desse comprimento de onda. É invisível para olhos humanos, e é a luminosidade mínima requerida para a operação do equipamento.
} 
O sistema de captação pode ser estático ou dinâmico. Os sistemas estáticos são mais dependentes da colaboração do usuário, já que ele mesmo se posiciona em relação à câmera. São utilizados espelhos, telas que reproduzem a imagem do olho ou miras para orientar o usuário no momento da obtenção da imagem. A maior parte dos equipamentos inclui também gravações sonoras de instruções para o usuário ${ }^{256}$.

Já os sistemas dinâmicos utilizam mecanismos de varredura da face para identificação dos olhos podendo iniciar o processo pela simples aproximação do usuário. Esses equipamentos utilizam lentes de grande angular, mas atualmente estão em minoria no mercado em razão de seu custo ainda mais elevado ${ }^{257}$.

As etapas de utilização do algoritmo e de manejo dos dados são realizadas por computadores equipados com processadores de alta desempenho, embora para pequenos sistemas de identificação processadores com características usuais sejam suficientes. Citem-se, exemplificativamente, o sistema biométrico para íris Irispass-M® fabricado pela Oki Electric Industry do Japão exige um processador de no mínimo $2 \mathrm{GHz}$, memória RAM mínima de 512 Mb e a utilização de Windows ${ }^{\circledR} 2000$ ou superior, exigências hoje modestas tendo-se em vista os computadores disponíveis no mercado. Já há também equipamentos que possuem a capacidade de armazenar dados biométricos irianos e identificar um determinado número de usuários sem a necessidade de utilização de um computador externo às câmeras ${ }^{258}$.

A biometria da retina exige uma câmera digital dotada de um conjunto óptico mais complexo. Isto se deve à dificuldade de focalização da retina em condições de pequeno diâmetro pupilar, já que o método é realizado sem a dilatação da pupila. No início, as câmeras utilizadas eram adaptações de equipamentos diagnósticos para a retina o que acarretava diversos problemas. Tais câmeras têm preço elevado e exigem maior luminosidade para sua operação, o que diminui a tolerância do usuário, além de quase sempre exigirem a participação de um técnico para sua operação.

Mais recentemente, equipamentos mais simples e específicos para o método foram desenvolvidos. Passou-se utilizar a faixa das ondas infravermelhas, invisíveis. Com isso a colaboração do usuário tornou-se mais fácil, porque o tempo de captura da imagem diminuiu. Atualmente, os equipamentos requerem apenas a fixação do olhar em

\footnotetext{
${ }^{256}$ John R. VACCA, Biometric technologies and verification systems, p. 76.

${ }^{257}$ Ver modelo LG Irisaccess3000® "Demo"em http://www.lgiris.com. Acesso em 04 de janeiro de 2008.

${ }^{258}$ Como por exemplo, os Panasonic BM-ET200® e 330®e o SecureMetrics Píer $®$.
} 
um ponto de luz (led) de baixa luminosidade, estando o usuário de $10 \mathrm{~cm}$ a $1 \mathrm{~m}$ do equipamento $^{259}$.

O algoritmo da biometria retiniano é obtido após a digitalização da imagem por um processo em tudo semelhante ao já descrito para a biometria da íris. No método biométrico retiniano hoje em uso, a imagem não precisa detalhar as estruturas existentes na retina, mas sim captar o reflexo dos raios infravermelhos na retina e corióide. $\mathrm{O}$ algoritmo do método avalia as variações desse reflexo em uma área circular considerando que os vasos da retina alteram o reflexo obtido. O modelo obtido é ainda menor que o iriano, com cerca de 96 bytes, o que facilita a manipulação das informações pelo sistema informatizado utilizado. $^{260}$

As duas formas de biometria ocular permitem a geração de um cartão ou mídia com o modelo biométrico criado pelo algoritmo específico. Dessa forma, é possível a verificação da identidade pretendida pelo portador do cartão.

Atualmente, existem no mercado diversos fabricantes de equipamentos para a biometria ocular, bem como companhias especializadas em projetar, instalar e certificar esses equipamentos em diferentes cenários, além de companhias que desenvolvem software específico do método. Há demanda por esses sistemas tanto na vida civil quanto em funções oficiais patrocinadas por agências de segurança governamental. $\mathrm{Na}$ vida civil, os sistemas de biometria ocular são utilizados no controle de acesso a determinados locais de circulação limitada, na autenticação/verificação de usuários de sistemas informáticos de acesso qualificado e na liberação de recursos financeiros a guarda de instituições. Já as entidades da administração pública utilizam os recursos da biometria ocular, não só para as finalidades descritas anteriormente, como também no controle do fluxo de pessoas por suas fronteiras, no registro de indivíduos para fins criminais, na confirmação da disponibilidade de certos benefícios aos seus reais destinatários e no combate ao terrorismo ${ }^{261}$.

São fabricantes de equipamentos para a biometria da íris, pode-se citar, entre outros, a LG Eletronics (Coréia), a Matsushita Electric Industrial Co., fabricante dos equipamentos Panasonic (Japão), a Oki Electric Industry (Japão), a SecuriMetrics Incorporated (Estados Unidos), a IrisGuard Inc. (Reino Unido) e a IrisTech Incorporated

\footnotetext{
259 John R. VACCA, Biometric technologies and verification systems, p.88 e 89; sítio da Retica Systems, http://www.retica.com

260 Ibid., p. 91. Novos sistemas de biometria retiniana em lançamento, no entanto, elaboram seus modelos biométricos pela análise da imagem retinianas dos vasos sangüíneos ao redor da papila.

${ }^{261}$ John R. VACCA, Biometric technologies and verification systems, p. 12.
} 
(Estados Unidos), que além de equipamentos desenvolve também softwares e algoritmos específicos e a Retica Systems Inc. (Estados Unidos). Quanto às empresas planejadoras de sistemas biométricos baseados na íris, citem-se a Iridian Technologies, (Estados Unidos) que certifica e desenvolve software para biometria da íris, Daon (Estados Unidos), ImageWare Systems Inc. (Estados Unidos), entre outras.

A maioria dos sistemas de biometria iriana no mercado usa os algoritmos do sistema IrisCode ${ }^{\circledR}$, cujas patentes pertencem a Iridian Technologies. $\mathrm{O}$ criador desse algoritmo, como já visto, é John Daugman, professor de Cambridge. Serão vistos a seguir alguns equipamentos que utilizam esse software.

A LG produz os equipamentos IrisAcces $4000 \AA$, que permitem o controle de acesso por meio da biometria de ambas as íris de forma isolada ou em combinação com outros sistemas de segurança, como a verificação simultânea de cartões de identificação e senhas. O sistema inclui as câmeras para o registro inicial no sistema e o hardware e o software para sua operação. Esse equipamento captura a imagem da íris de forma passiva, isto é, o usuário deve apresentar-se para as câmeras e fixar o olhar em sua direção para que a biometria iriana seja realizada. O software IrisAccelarator ${ }^{\circledR}$ permite a análise de 12 milhões de modelos biométricos de íris a partir dos dados capturados pelas câmeras do IrisAccess ${ }^{\circledR}$. A companhia afirma ser a líder mundial em implementação da tecnologia da biometria da íris ${ }^{262}$.

A Matsushita produz equipamentos de controle de acesso por biometria da íris semelhantes aos da LG. São os modelos Panasonic BM-ET 200® e BM-ET $330 \AA$. Ambos podem operar isoladamente armazenando dados de 50 (modelo 220) até 1000 usuários (no modelo 330). Em rede, o sistema opera com até 10.000 registros. Não há modelos com associação de tecnologias de identificação, no entanto. $\mathrm{O}$ fabricante não produz, tampouco hardware específico para o sistema. São basicamente câmeras de captura passiva da imagem que operam com software fornecido por outras empresas ${ }^{263}$.

A Oki Eletric Industry produz o Irisspass-M ${ }^{\circledR}$, câmera capaz de captar a imagem de uma ou de ambas as íris e que processa a informação biométrica por meio

\footnotetext{
${ }^{262}$ Informações disponíveis no sítio da companhia http://www.lgiris.com acesso em 03 de janeiro de 2007. A companhia produzia também o IrisAccess $3000^{\mathrm{TM}}$, ora descontinuado, que possuía um mecanismo ativo de captura da imagem iriana, dirigindo suas câmeras para os olhos do usuário assim que ele entrava no campo de ação do equipamento.

263 Informações do sítio do fabricante http://www.panasonic.com/business/security/products/biometrics.asp, acesso em 04 de janeiro de 2008.
} 
de software da Iridian Technologies. É também um sistema de câmeras passivas de captura de imagem iriana $^{264}$.

A SecuriMetrics produz equipamentos portáteis de captura de imagem e armazenamento de modelos biométricos irianos em sistemas com base de dados próprios ou de uma rede de computadores. São eles o Píer ${ }^{\circledR}$ totalmente portátil que opera com uma base de dados interna de 200.000 modelos de íris ou em rede ligado a um computador, o que permite a comparação dos dados obtidos com milhões de modelos armazenados no sistema; o Píer-T, que é uma câmera portátil de obtenção da imagem iriana para processamento que opera ligada a um computador, o HIIDE® series 4, que é um equipamento portátil para identificação multibiométrica de indivíduos, utilizando a combinação de dados da íris e das papilas dérmicas, podendo armazenar dados de 10.000 indivíduos para comparação posterior, sem ajuda de um computador ou ligado a um deles, e o Multi-Modal Biometric Demonstration Device (MMBD9)®, que é uma base informática montada em um computador para múltipla operação de dados biométricos, da íris, das papilas dérmicas e outros. Esses equipamentos têm tido larga aplicação nas operações de guerra do Iraque e na repressão do crime nos Estados Unidos, já que sua mobilidade é muito útil para operações de campo $^{265}$.

A Iris Guard Inc. produz a câmera IrisGuard IGH100®, com tecnologia Sony e que apresenta como diferencial a possibilidade de ser utilizada de forma portátil. Este equipamento está sendo utilizado em aeroportos como o de Dubai, no Golfo Pérsico e em instalações governamentais de imigração britânicas ${ }^{266}$.

Outras companhias também produzem equipamentos para biometria iriana, utilizando-se de softwares e algoritmos próprios, como a IrisTech, que os aplica em seu sistema de câmeras denominado Neoris $2000 \AA$, que tem como diferencial a possibilidade de captação da imagem facial e iriana simultaneamente ${ }^{267}$ e a Retica Systems, que produz o Mobile-eyes ${ }^{\circledR}$ um equipamento portátil para biometria ocular que opera ligado a um computador que utiliza software da companhia para armazenamento e comparação dos

\footnotetext{
264 Informações do fabricante em seu sítio http://www.oki.com/jp/FSC/iris/en/index.html, acesso em 03 de janeiro de 2008 .

${ }^{265}$ Informações do sítio da companhia http://www.securimetrics.com/solutions/index.html, acesso em 04 de janeiro de 2008 .

${ }^{266}$ Informações do sítio da companhia http://www.irisguard.com , acesso em 05 de janeiro de 2008.

${ }^{267}$ Informações do sítio da companhia http://www.iritech.com/index.html acesso em 04 de janeiro de 2008.
} 
modelos biométricos ${ }^{268}$. Estas empresas, no entanto, têm ainda participação marginal no mercado.

Equipamentos para a biometria da retina são ainda bastante raros. A primeira companhia que os produziu foi a EyeDentify, Inc. (Estados Unidos) que utilizou inicialmente a tecnologia de câmeras retinianas de uso médico. Os primeiros equipamentos testados, como já citado anteriormente, apresentavam grande dificuldade de interação com o usuário, tornando o processo excessivamente demorado e pouco tolerado. Tais dificuldades impediram seu efetivo lançamento no mercado.

Posteriormente, foi aperfeiçoada a tecnologia de obtenção da imagem retiniana por meio de luz infravermelha, o que melhorou grandemente a desempenho do sistema e em 1981 foi lançado o primeiro sistema biométrico com possibilidades comerciais o EyeDentification 7.5®. Embora mais apropriado para utilização prática, ainda se valia de um sistema complexo e caro demais o que restringiu sua implementação ao controle de acesso de recursos militares de alta segurança. A mesma companhia, por essas razões, lançou o ICAM 2001®, um sistema aperfeiçoado de biometria retiniana que permitia o armazenamento de 3000 modelos biométricos.

No entanto, mais problemas obrigaram a empresa a praticamente encerrar a produção de equipamentos para biometria retiniana ${ }^{269}$. No momento, outra companhia entrou no mercado de biometria da retina, a Retica Systems (Estados Unidos), sucessora da Retinal Technologies, LLC que desenvolve um sistema de biometria da retina com tecnologia de hardware e software próprios, produzindo também equipamentos que combinam a biometria retiniana com a da íris, denominado comercialmente Cyclops ${ }^{\circledR}{ }^{270}$.

\subsection{MODO DE OPERAÇÃO DA BIOMETRIA OCULAR}

A operação da biometria ocular é realizada de maneira semelhante pelos diversos aparelhos hoje existentes. Algumas condições devem ser observadas para a maior eficiência do método. Como os sistemas irianos e também os retinianos dependem de captação da imagem, a iluminação e os reflexos no ambiente têm de ser controlados. Para a

\footnotetext{
${ }^{268}$ Informações do sítio da companhia http://www.retica.com/site/technology/index.html acesso em 04 de janeiro de 2008.

269 John R. VACCA, Biometric technologies and verification systems, p. 88.

${ }^{270}$ David USHER, Yasunari TOSA e Marc FRIEDMAN, Ocular biometrics: simultaneous capture and analysis of the retina and iris in Advances in biometrics, p. 133 a 155.
} 
biometria da íris, existem padrões de iluminação e operação estabelecidos, como o padrão ANSI/INCITS (American National Standard for Information Technology) ${ }^{271}$ que visa a padronização de dados informáticos da íris entre diversas plataformas e para isso estabelece condições mínimas de qualidade das imagens iriana. Já para a biometria da retina não há ainda padrões estabelecidos, porém, para o último equipamento comercialmente viável a iluminação do ambiente deveria evitar o fechamento excessivo da pupila (miose) ${ }^{272}$.

O usuário aproxima-se do aparelho a uma distância de 30 a $90 \mathrm{~cm}$ e focaliza uma mira iluminada que serve para fixação e centralização dos olhos. O usuário é orientado por uma gravação em quase todos os sistemas. A maior parte dos aparelhos de biometria iriana avaliam as duas íris simultaneamente, mas há os que fazem a leitura de um olho por vez. A instalação mais comum é montada em posição vertical exigindo que o usuário permaneça em pé à frente deles. Alguns fabricantes, entretanto, produzem modelos portáteis, como o PIER $\AA$ e o IrisGuard ${ }^{\circledR}$. Usualmente, a rapidez de captação da imagem e a ausência de iluminação desagradável ao usuário na biometria da íris tornam o método bastante tolerado, ao passo que os sistemas em operação para a biometria da retina exigem maior cooperação pelo tempo maior dessa captação, especialmente na fase de registro inicial do modelo ${ }^{273}$.

A captação das imagens e o processamento do modelo biométrico levam cerca de 1 segundo para a biometria da íris em todos os modelos. A comparação entre os modelos biométricos também é muito rápida, podendo ser comparados 1.000.000 de modelos por segundo em um processador de $2 \mathrm{Ghz}^{274}$.

A captação do reflexo retiniano pelo equipamento EyeDentification $7.5 \circledR$ é feita monocularmente, e o tempo de captação pode ser relativamente longo. Não se conhecem ainda as condições exatas de operação do sistema biométrico irido-retiniano a ser comercializado pela Rética Inc. o Cyclops.

\footnotetext{
${ }^{271}$ David USHER, Yasunari TOSA e Marc FRIEDMAN, Ocular biometrics: simultaneous capture and analysis of the retina and iris in Advances in biometrics, p. 146.

${ }^{272}$ Robert B. HILL, Retina identification in Biometrics persona identification in networked society, p. 136.

${ }^{273}$ John R. VACCA, Biometric technologies and verification systems, p. 88.

${ }^{274} \mathrm{Ibid}$., p. 75.
} 


\subsection{UTILIZAÇÃO DA BIOMETRIA OCULAR}

A biometria da íris está, no momento, sendo utilizada nos seguintes cenários:

- controle de acesso a locais de uso restrito como instalações industriais, condomínios, instituições governamentais, escolas e outros;

- controle de fronteiras e de imigração em países do Golfo Pérsico;

- facilitação de reconhecimentos de passageiros em diversos aeroportos do mundo, como alguns do Canadá, Estados Unidos e países do Golfo Pérsico;

- controle de utilização de celulares e equipamentos eletrônicos;

- confirmação do olho a sofrer algum tratamento invasivo, estando o sistema biométrico incorporado ao equipamento a ser utilizado;

- controle de internos em presídios dos Estados Unidos;

- alguns caixas eletrônicos ${ }^{275}$.

Quanto à biometria da retina, tem-se conhecimento de que vem sendo ela utilizada apenas em algumas instalações militares norte-americanas de alto grau de segurança $^{276}$.

Uma das possíveis aplicações das técnicas de biometria ocular consiste na sua utilização em perícias judiciais. É do que se tratará na próxima parte.

\footnotetext{
${ }^{275}$ John R. VACCA, Biometric technologies and verification systems, p. 81 a 83 .

${ }^{276}$ Ibid., p. 92.
} 
PARTE III

BIOMETRIA OCULAR

E PERÍCIA JUDICIAL 


\section{CAPÍTULO VI. PERÍCIA E BIOMETRIA OCULAR}

Perícia é todo exame solicitado por autoridades competentes e feito por técnicos qualificados para analisar elementos materiais mais ou menos permanentes trazidos em um processo. As perícias comprovam a veracidade dos fatos alegados pelas partes e pela autoridade policial a pedido da autoridade que conduz o feito ${ }^{277}$. Perito é o especialista em alguma área do conhecimento humano que pode cientificamente comprovar e interpretar um fato, examinar uma pessoa ou alguma coisa a partir dos conhecimentos específicos que $\operatorname{possui}^{278}$.

Assim é que cada área de conhecimento conta com um tipo de perito diferente. Há peritos em engenharia, em informática, em ciências contábeis, em química e também em medicina. Perícia médico-legal é aquela que requer conhecimentos e habilitação médica para sua realização, especificamente a médico-legal ${ }^{279}$.

As técnicas biométricas podem tanto servir de instrumento para uma perícia como serem objeto de perícia. Assim, podem-se utilizar técnicas de identificação biométrica na perícia médico-legal ou judiciária da identidade, mas também, o uso de biometria por qualquer instituição pode ser objeto de perícia, com o objetivo de avaliar a qualidade técnica e validade científica do procedimento realizado.

Como exemplo de uso da biometria como técnica de identificação, usada em perícia, pode-se citar o uso de escaneamento de papilas digitais por escaner biométrico em um indivíduo vivo ou morto para comparar o modelo obtido com os dados de um arquivo. Ou ainda, o uso de biometria da íris para verificar a presença de todos os sentenciados que cumprem pena em determinada instituição em determinado momento. É uma perícia que pode ser considerada médico-legal ou simplesmente a aplicação de uma técnica de identificação judiciária.

Como exemplo de perícia da técnica biométrica, pode-se citar a verificação da validade da recusa de acesso de alguém baseada em leitura biométrica da retina a uma determinada localidade protegida. Ou ainda, a verificação da validade da não liberação de recursos financeiros a alguém que se declara seu proprietário baseada na não validação de

\footnotetext{
${ }^{277}$ Hélio GOMES, Medicina legal, p. 28.

${ }^{278}$ Eduardo R.A. DEL-CAMPO, Medicina legal, p. 14.

${ }^{279}$ Odon Ramos MARANHÃO, Curso básico de medicina legal, p. 31 e 32.
} 
sua identidade por equipamento biométrico iriano. Essa é uma perícia que compete mais a um perito em informática e eletrônica do que propriamente a um perito médico-legal ou judiciário.

Serão vistos a seguir alguns aspectos desses dois tipos de perícia com relação à biometria ocular.

\subsection{PERÍCIA DA IDENTIDADE PELA BIOMETRIA DAS ESTRUTURAS OCULARES}

A perícia para identificação médico-legal tem por finalidade a identificação de determinada pessoa viva ou morta ou de partes de um corpo. Também tem a finalidade de determinar determinados parâmetros biotipológicos, como espécie, sexo, fenótipo, idade, e outros. Esses parâmetros, como já visto anteriormente, têm importância em diversas áreas jurídicas, como a penal, a civil, a previdenciária, a trabalhista e outras ${ }^{280}$.

A biometria não se presta a uma identificação pessoal absoluta. A única técnica biométrica que poderia pretender esse objetivo seria a biometria dos caracteres genéticos do DNA, que é ainda de difícil realização. O que mais se aproxima de uma biometria do DNA é a confecção de cartões de identificação com o "DNA fingerprint" do indivíduo para que após a coleta de seu material biológico, alguém pudesse ser identificado pelo estudo bioquímico de seu DNA, o que demora algumas horas ${ }^{281}$.

A biometria ocular, seja a da íris, seja a da retina, ainda pouco oferece para a identificação médico-legal. A rigor, uma correspondência entre o modelo biométrico apresentado e o arquivado diz apenas isto: os modelos têm grande probabilidade de corresponderem a caracteres biométricos idênticos, mas que não identificam por si só ninguém. A identificação é necessariamente externa ao sistema, certificada por instituição oficial de fé pública para tanto, e associada ao modelo biométrico realizado no registro inicial.

Além disso, as biometrias oculares requerem que o indivíduo esteja vivo para sua aplicação. Tanto para a íris, quanto para a retina, a opacidade dos meios oculares que surge no pós-morte prejudica o exame, em razão da tela viscosa e da opacificação corneana que ocorrem respectivamente em poucos minutos e em 6 a 8 horas da

\footnotetext{
${ }^{280}$ Hermes R. ALCÂNTARA, Perícia medico judicial, p. 24.

${ }^{281}$ John R. VACCA, Biometric technologies and verification systems, p. 245 e 246.
} 
morte $^{282}$. No caso da íris, se retirada a córnea, seria possível realizar a leitura de sua superfície, porém, os parâmetros biométricos padrão estariam alterados devido às alterações anatômicas que essa manobra acarreta. Já para a retina, a ausência de circulação imediata no pós-morte impede a realização do método. Saliente-se aqui que tanto a biometria da íris, quanto a da retina requerem padrões de fixação ocular ativos e voluntários por parte do usuário, o que obviamente implica que o indivíduo a ser identificado esteja vivo.

Já para a perícia judiciária da identidade, a biometria de estruturas oculares oferece maior valor. Quase todos os requisitos de validade científica de um método de identificação são por elas atendidos: a unicidade, a imutabilidade (perenidade), a variabilidade (classificabilidade) e a praticabilidade ${ }^{283}$, cabendo algumas ressalvas quanto ao requisito da imutabilidade.

Além de atenderem esses requisitos, as biometrias oculares atendem também a outros, próprios dos sistemas biométricos, como por exemplo, a desempenho do método, a universalidade dos traços biométricos oculares, a mensurabilidade desses traços, sua aceitação pelo usuário e a segurança em sua utilização demonstrada pela dificuldade de fraudes contra o sistema.

Em uma perícia judiciária da identidade pela biometria ocular devem-se, no entanto, levar-se em consideração algumas diferenças entre a identificação judicial padrão, que é a datiloscópica e a identificação biométrica.

Os procedimentos biométricos em geral, incluindo-se os oculares, são essencialmente sistemas de autenticação e não de identificação. Em outras palavras, esses sistemas realizam a comparação "um para um" (1-1) em preferência à comparação "um para muitos" (1-n). Mesmo quando se compara um modelo biométrico para identificar seu fornecedor, na verdade, o sistema faz operações um a um entre o modelo que se pretende reconhecer e todos os modelos armazenados. Não é possível interromper-se a comparação em algum ponto, mas somente ao final do processo após a comparação entre todos os modelos e aquele em questão pois, somente então, poder-se-á concluir se aqueles traços biométricos correspondem ou não a algum dos armazenados no arquivo de dados ${ }^{284}$.

\footnotetext{
${ }^{282}$ Hélio GOMES, Medicina legal, p. 106; Flamínio FÁVERO, Medicina legal, vol. 2 página 95.

${ }^{283}$ Ver item 2.3.1 supra, p. 46 a 48.

${ }^{284}$ Damien DESSIMOZ e Christophe CHAMPOD, Linkage between biometrics and forensic science, in Handbook of biometrics, p. 425 a 459.
} 
Isso ocorre porque o método de comparação (matching) dos sistemas biométricos é fundamentalmente estatístico. Como já foi visto acima, os algoritmos de verificação entre os modelos biométricos utilizam-se de fórmulas e métodos de pareamento estatísticos e determinam a correspondência por meio de limiares de probabilidade. Por exemplo, no "matching" pelos IrisCodes, de Daugman, uma distância de Hamming menor que 0,33 corresponde a identidade entre os modelos ${ }^{285}$.

Assim, baseado na biometria da íris, um perito judicial só pode afirmar o grau de probabilidade da identidade de alguém. O método biométrico deve fornecer então essa probabilidade e talvez algumas identidades alternativas com menor probabilidade de correspondência. $\mathrm{O}$ mesmo se aplica à biometria da retina.

O perito judicial deve expressar o resultado de suas perícias pela razão de verossimilhança ("likelihhod ratio") de sua conclusão em todos os domínios em que a certeza não é alcançável. Essa razão é uma relação entre a probabilidade de validade e a probabilidade de não validade de uma prova em determinado contexto judicial. No caso da identificação biométrica, a razão de verossimilhança é obtida relacionando-se a taxa de concordâncias e discordâncias entre a amostra biométrica a identificar e a existente no arquivo, consideradas as circunstâncias do caso, e as chances que essa amostra não seja de alguém no arquivo. No fundo, a razão de verossimilhança exige que o perito leve em consideração as circunstâncias de cada caso para determinar a identidade de alguém com base em sistemas biométricos, e não utilizar exclusivamente os cálculos próprios de cada algoritmo em seu laudo pericial ${ }^{286}$.

O perito judicial deve também conhecer idealmente as condições de operação do método biométrico ocular para avaliar a validade das identificações por eles realizadas. Os padrões de qualidade e aferição que ora estão em desenvolvimento para a íris devem nortear sua interpretação, sendo que se a operação do sistema tiver sido inadequada, as conclusões não são possíveis nem mesmo no plano das probabilidades. Por evidente, é requerido do perito um conhecimento mínimo da tecnologia de imagem e de informática utilizada no método para melhor avaliar a razão de verossimilhança. A precisão na confecção do registro inicial, a segurança do banco de dados e a qualidade no sistema de captação do

\footnotetext{
${ }^{285}$ James R. MATEY et al., Iris recognition in less constrained environments in Advances in Biometrics, p.114.

${ }^{286}$ Damien DESSIMOZ e Christophe CHAMPOD, Linkage between biometrics and forensic science, in Handbook of biometrics, p. 425 a 459.
} 
modelo biométrico a ser testado devem também ser objeto da atenção do perito na confirmação ou não da resposta biométrica ocular obtida.

\subsection{PERÍCIA DA VALIDADE DO SISTEMA DE IDENTIFICAÇÃO BIOMÉTRICO}

Os sistemas de identificação biométricos devem obedecer a padrões mínimos de operação para que seus resultados sejam válidos. Os sistemas de captação de imagem, de processamento de dados, os algoritmos de codificação do modelo biométrico, a captação da amostra a ser validada, o algoritmo de comparação e os critérios de reconhecimento ou de recusa de autenticação devem atender às exigências das instituições e dos usuários envolvidos. Além disso, cada sistema biométrico é adequado para uma determinada atividade, sendo fundamental avaliar-se a pertinência do método para a finalidade pretendida. Uma perícia desses sistemas é necessária sempre que as decisões tomadas a partir dos dados por eles fornecidos sejam apreciadas em juízo.

Para essa perícia, o perito pode basear-se nos padrões internacionais para as técnicas biométricas que estão sendo elaborados por entidades como a NIST (National Institute for Standards and Technology dos Estados Unidos) e ISO (International Standard Organization) em fóruns internacionais sobre essas técnicas ${ }^{287}$.

Padronização é uma resposta à necessidade de interoperabilidade entre sistemas. A padronização tem efeitos importantes no mercado de qualquer equipamento, permitindo o surgimento de fornecedores independentes dos fabricantes originais, impedindo assim, monopólios e "lock-ins". Além disso, a padronização permite a integração entre diferentes módulos de tecnologia facilitando a atualização ("up grade”) de equipamentos e o surgimento de novos fornecedores. Um efeito negativo da padronização, por outro lado, é a diminuição do estímulo para o surgimento de patentes, pois é a exclusividade na exploração dos sistemas que estimula a inovação tecnológica ${ }^{288}$.

As duas organizações já citadas, a NIST nos Estados Unidos e a ISO no plano internacional, têm trabalhado na elaboração de padronização tecnológica para biometrias de todas as modalidades. Há também outras organizações chamadas de SDO (standard development organizations) trabalhando em padrões biométricos como o

\footnotetext{
${ }^{287}$ Patrick GROTHER, Biometric Standards, in Handbook of Biometrics, p. 511.

${ }^{288}$ Ibid., p. 509.
} 
International Biometric Group e a International Biometric Industry Association ${ }^{289}$, porém, com repercussão menor.

A NIST tem trabalhado nos Estados Unidos com organizações governamentais como o United States Biometric Consortium e a INCITS (International Comitee for Information Technology Standards) para estabelecer padrões biométricos considerados essenciais para a segurança nacional de seu país após os atentados ocorridos em 11 de setembro de 2001, especialmente para controle de acesso nas fronteiras do país. Um dos primeiros resultados foi a plataforma BioAPI que permite a conexão e troca de dados entre diferentes sistemas biométricos.

Essas organizações norte-americanas têm liderado o esforço internacional para padronização de sistemas biométricos como forma de aplicação de sua política de segurança interna. Assim, o comitê americano de padronização biométrica conhecido como M1, lidera o subcomite 37 (SC 37) da ISO denominado Biometrics ${ }^{290}$.

Alguns dos trabalhos de padronização em realização no subcomitê são a padronização do vocabulário biométrico, da interface entre sistemas, do BioAPI, dos testes de conformidade, dos "frameworks" (quadros) de troca de informação biométrica, sistemas multimodais, de pontos particulares em datiloscopia, imagem facial e finalmente, das imagens irianas. Há também padronização dos testes de desempenho, de segurança e de questões jurídicas e sociais ${ }^{291}$.

Baseados nesses padrões, que são publicados por essas associações e vendidos, o perito pode avaliar se o sistema biométrico objeto de sua perícia é confiável e válido, fornecendo decisões passíveis de serem aceitas em juízo. O desempenho dos técnicos que operam esse sistema também pode ser avaliado pelos mesmos padrões.

Quanto à perícia específica dos sistemas de biometria ocular, há mais dados padronizados para a biometria da íris, por ser essa técnica mais difundida que a biometria retiniana. No entanto, os padrões genéricos de biometria podem ser utilizados na avaliação de um sistema de biometria da retina, bem como a verificação dos equipamentos, condições de utilização e operação.

\footnotetext{
${ }^{289}$ Ver sites dessas instituições http://www.biometricgroup.com e http://www.ibia.org.

${ }^{290}$ John R. VACCA, Biometric technologies and verification systems, p. 57-70.

${ }^{291}$ Patrick GROTHER, Biometric standards, in Handbook of Biometrics, p. 512-527.
} 


\subsection{IDENTIFICAÇÃO CIVIL E CRIMINAL E BIOMETRIA OCULAR}

A identificação civil, como já citado, é o processo de identificação para o exercício de certos direitos na vida privada. Para contrair o casamento, por exemplo, cada um dos noivos deve comprovar sua identidade. Na celebração dos contratos, os participantes devem identificar-se por meio de documentos civis idôneos. Para abertura de contas correntes em instituições bancárias e em algumas transações, o cliente deve identificarse.

A identificação criminal é a realizada pelo Estado no exercício de seu direito/dever de punir na defesa dos bens jurídicos de dignidade penal. Abrange não só a identificação dos acusados como também das vítimas. As normas penais, tanto as de direito material como as processuais estabelecem as circunstâncias e as situações em que essa identificação é imprescindível, limitando sua realização entre outras razões pelo princípio da presunção de inocência ${ }^{292}$ (artigo 5º LVII, da Constituição da República, de 1988).

As técnicas de biometria ocular, especialmente a da íris, são de grande utilidade para a vida civil, já que se prestam perfeitamente para a validação da identidade (em termos biométricos, na comparação 1-1). Para as operações financeiras como saques em caixas automáticos, por exemplo, a biometria da íris pode com grande acerto e rapidez validar a identidade do usuário. O controle de acesso a alguns locais também pode utilizar a biometria da íris com segurança.

Seria também possível a utilização das técnicas biométricas na identificação civil realizada pelos órgãos oficiais. Nas cédulas de identidade ou em outros documentos equivalentes poderiam ser incluídos dados de biometria para que o indivíduo pudesse também comprovar sua identidade com técnicas biométricas. Algumas iniciativas oficiais para a criação de documentos com recursos de autenticação biométrica já estão em curso no Brasil.

É de se ressaltar, o início da utilização da tecnologia biométrica de autenticação da identidade nas eleições brasileiras. O Tribunal Superior Eleitoral por meio da resolução 22.688/2008 determinou o recadastramento eleitoral em três municípios de diferentes regiões colhendo, na oportunidade, além dos dados de identidade usuais, registros biométricos das impressões digitais de todos os dedos de cada eleitor. Formou-se assim um

\footnotetext{
${ }^{292}$ Mário Sérgio SOBRINHO, A identificação criminal, p. 75 e 76.
} 
banco de dados biométricos que foi utilizado na autenticação do voto eletrônico em urnas equipadas com dispositivos biométricos de impressões digitais nas eleições municipais daqueles municípios em 2008. A experiência visava, segundo o Tribunal, a padronização do método para que em dez anos todas as urnas do país estejam adaptadas aos sistemas biométricos por impressões digitais. Espera-se, assim, obter uma segurança maior nos pleitos, por evitar-se dessa forma que outras pessoas votem em lugar do eleitor. Aliás, a biometria da íris, também serviria perfeitamente a esse papel.

O desenvolvimento do projeto levará à criação de um banco de dados nacional de impressões digitais que poderá servir para que outros documentos possam ser beneficiados desse mecanismo de autenticação e identificação biométrica ${ }^{293}$.

A identificação criminal pela biometria da íris tem aplicação mais restrita, já que para esta importa mais a identificação 1-n, ou a determinação da identidade de cada indivíduo em confronto com todos os demais. Essa identificação depende da formação de um banco de dados biométricos irianos para sua efetiva realização. Se a identificação civil passasse a ser feita com dados biométricos, esse banco de dados poderia ser montado. No momento, nos Estados Unidos o FBI iniciou um banco de dados biométricos de apenados e suspeitos. Esse banco de dados inclui a biometria da íris de suspeitos e criminosos detidos no Afeganistão e Iraque ${ }^{294}$.A biometria ocular, no entanto, pode ser útil no controle do acesso e deslocamento dos internos e visitantes nos sistemas prisionais, desde que seus modelos biométricos sejam arquivados anteriormente.

\footnotetext{
${ }^{293}$ Os municípios escolhidos foram Fátima do Sul em Mato Grosso do Sul, Colorado D’Oeste em Rondônia e São João Batista em Santa Catarina. Os três municípios possuem por volta de 14.000 eleitores de condições sócio-econômicas e escolaridade semelhantes. Além disso, todos teriam que passar por um processo de recadastramento eleitoral motivado por outras razões. Foram fornecidos todos os equipamentos necessários para o cadastramento biométrico e também treinamento para o pessoal que o operou. A experiência mostrou-se bem sucedida e deve ampliar-se nos próximos pleitos. Identificação biométrica in http://www.tse.jus.br/internet/eleicoes/index.htm acesso em 15 de janeiro de 2009.

294 "FBI prepara maior banco de dados biométricos do planeta" in http://www.htmlstaff.org/ver.php?id=15281 acesso em 20 de janeiro de 2008.
} 


\section{CAPÍTULO VII. UTILIZAÇÃO DA BIOMETRIA OCULAR COMO MEIO DE PROVA JUDICIÁRIA.}

A utilização da biometria ocular como meio de prova aceita em juízo depende em uma análise global de sua confiabilidade e de sua segurança. O perito que utilizá-la como forma de identificação ou que avaliar a validade de uma identificação biométrica feita por outros perante o juiz deve ter em mente que, como qualquer outra técnica, a confiabilidade e a segurança dessa modalidade biométrica não são absolutas.

Cabe salientar que, dadas às características anatômicas da íris e da retina, bem como da tecnologia utilizada, é possível afirmar que a variabilidade, unicidade e classificabilidade das amostras atendem perfeitamente aos critérios científicos dos métodos de identificação humana utilizados para funções forenses. Desse ponto de vista, a biometria das estruturas oculares é um método extremamente confiável. No entanto, como se verá a seguir, não é possível afirmar que os caracteres utilizados na biometria da íris e da retina são imutáveis, havendo em certas situações mudanças suficientes para justificar um procedimento de recadastramento dos indivíduos ao longo do tempo.

Serão vistos agora alguns outros aspectos da confiabilidade e da segurança da biometria ocular. Mais uma vez, os principais dados disponíveis referem-se à biometria da íris, sistema em utilização mais difundido na atualidade que o sistema de biometria retiniano.

\subsection{CONFIABILIDADE DA BIOMETRIA OCULAR.}

A confiabilidade da biometria da íris tem sido comprovada por numerosos estudos técnicos desde o início de sua utilização prática ${ }^{295}$. Grupos independentes como o International Biometrics Group têm realizado testes com os diferentes equipamentos e programas informáticos existentes, comprovando que os equipamentos utilizados apresentam taxas de desempenho elevadas na identificação positiva e negativa. Os testes realizam todas as fases da identificação em voluntários e também com dados obtidos em bancos de dados irianos padrão, tais como o CASIA 1.0, 2.0, e 3.0, UPOL e UBIRIS ${ }^{296}$.

\footnotetext{
${ }^{295}$ Independent test of iris recognition technology, final report 2005 DAUGMAN, John. Probing the uniqueness and randomness of IrisCodes: results from 200 billion iris pairs comparisons ...

${ }^{296}$ Patrick J. FLINN in Handbook of biometrics, p. 541. Os bancos de dados de modelos biométricos têm a finalidade de servirem como padrões de estudo da desempenho de vários sistemas biométricos, havendo também
} 
Além disso, a utilização da biometria da íris em serviços de imigração de aeroportos e portos por alguns países (como os Emirados Árabes Unidos e o Reino Unido) permitiu a realização de bilhões de comparações entre modelos armazenados e a serem identificados, tendo-se demonstrado um nível de desempenho elevado do método para essas finalidades ${ }^{297}$.

Esses estudos obtiveram uma taxa de falsa rejeição (FNMR) de 2,5 \% e de falsa aceitação (FMR) $<0,0001 \%$ ( 1:1.200.000). A taxa de "equal error" foi igual a 1 em 1,2 milhão ${ }^{298}$. Tais índices permitem afirmar que a possibilidade de erro na identificação pela biometria da íris é muito próxima de zero.

No entanto, há situações em que resultados não satisfatórios podem ocorrer. Por exemplo, a inadequada captação da imagem pela câmera do sistema não permite um desempenho eficiente da biometria da íris. De fato, a captação da imagem iriana pelo sistema é o mais influente fator a gerar falhas na identificação pela íris ${ }^{299}$. A qualidade da imagem pode ser afetada por um grande número de fatores, como distância do olho para a câmera, iluminação do local, movimentos oculares ou maus posicionamentos dos olhos, presença de lentes e próteses, doenças que diminuam a transparência dos meios ópticos do olho e outros fatores.

Alguns fatores dependentes do equipamento informático utilizado também diminuem a confiabilidade do método. Por exemplo, o tempo em que os dados são captados e processados pode levar a baixa colaboração do indivíduo durante o processo. Outro fator é o "volume de captura" da imagem, ou seja, a área de focalização do indivíduo que o equipamento necessita abranger para adequadamente registrar os dados da imagem.

Com a evolução dos equipamentos de captura de imagem e de recursos de informática, esses fatores tendem a ser menos críticos na operação da biometria ocular, mas, no momento, representam fatores de erro muito importantes. Tais dificuldades são potencializadas pela má operação do sistema por pessoal não habilitado.

os bancos de impresses digitais, face, voz e etc. São registrados os modelos e os exemplos para teste, i.e. a foto da iris, a amostra da fala e etc.

${ }^{297}$ John DAUGMAN, Probing the uniqueness and randomness of IrisCodes: results from 200 billion iris pairs comparisons...

${ }^{298}$ John R. VACCA, Biometric technologies and verification systems, p. 79 a 81 e 450.

299 James R. MATEY et al, Advances in biometrics, p. 131. 
Um exemplo da associação desses fatores de erro ocorreu no Reino Unido quando da implementação do sistema IRIS (Iris Recognition Immigrant System) de identificação de imigrantes. Em sua primeira avaliação o sistema apresentou uma taxa de falha no cadastramento (FTER) de $60 \%$, falhas atribuídas exclusivamente à má utilização da tecnologia utilizada ${ }^{300}$. O adequado treinamento dos operadores e a rigorosa verificação das condições de operação asseguram a obtenção das altas taxas de confiabilidade que o método apresenta, o que no exemplo do Reino Unido, ocorreu posteriormente.

A íris humana sofre alterações anatômicas com o processo do envelhecimento. Seu relevo torna-se mais pobre em conseqüência da perda de substância do estroma. Assim, as criptas, traves, colarette modificam-se, o que altera a imagem captada pelo sistema biométrico diminuindo as chances de pareamento com as amostras armazenadas. Em alguns casos o IrisCode pode tornar-se significativamente diferente. Sua pigmentação também se altera, havendo perda de pigmentos ${ }^{301}$.

Condições patológicas também alteram o relevo iriano. Indivíduos que apresentam glaucoma de ângulo estreito e glaucoma pigmentar, por exemplo, exibem grandes alterações do tecido iriano, suficientes para alterar o IrisCode. A iridociclite heterocrômica de Fuchs, doença inflamatória da íris, acarreta a perda da pigmentação e do relevo iriano suficiente para dificultar a biometria. Alguns medicamentos de uso crônico podem modificar a superfície e coloração da íris, como o antiglaucomatoso Pilocarpina. Cirurgias do segmento anterior, como a facoemulsificação para correção de catarata ou a trabeculectomia para o tratamento de glaucoma, podem levar a dificuldades suficientes para alterar a precisão do método ${ }^{302}$. Pupilas dilatadas por medicamentos também diminuem sua precisão $^{303}$.

As alterações da retina dependentes tanto do envelhecimento quanto de situações patológicas (diabetes, hipertensão, vasculites e outras) podem impor restrições à confiabilidade da biometria retiniana, revelando que a perenidade dos caracteres utilizados nesse método de identificação também é relativa ${ }^{304}$.

\footnotetext{
${ }^{300}$ John LETTICE, UK iris airport biometric system flunks its exams disponível em http://www.theregister.co.uk/2007/01/11/project_iris_evaluation_report/.

${ }^{301}$ Ver item 3.2 supra, p. 64.

${ }^{302}$ R. ROIZENBLATT et al. Iris recognition as a biometric method after cataract surgery.

${ }^{303}$ Karen HOLLINGSWORTH et. al Pupil dilation degrades iris biometrics performance

${ }^{304}$ Ver item 3.3 supra, p. 67.
} 
Essas restrições à confiabilidade da biometria ocular devem ser analisadas juntamente as restrições à segurança em sua utilização, o que será visto a seguir.

\subsection{SEGURANÇA DA BIOMETRIA OCULAR}

A segurança é a ausência de riscos ou perigos. Em sistemas informáticos, o termo segurança refere-se à capacidade do sistema de proteger suas informações e recursos com respeito a sua integridade e sigilo ${ }^{305}$. Ao se abordar a segurança na biometria deve-se ter em mente que o sistema opera em um ambiente considerado hostil, ou seja, em um ambiente em que a possibilidade de atentados à segurança é constante. A necessidade de identificar alguém, aliás, decorre da impossibilidade de confiança irrestrita na autoidentificação.

Os sistemas biométricos são vulneráveis em todas as fases de sua operação havendo possíveis ataques específicos a cada uma delas. É evidente que as defesas devem ser desenvolvidas levando-se em conta essas fases. A prevenção das vulnerabilidades é possível, porém, uma das características dos ataques é sua infinita variabilidade que depende de um trabalho criativo por si só impossível de antecipar.

Maltoni et al. classificam os ataques nos seguintes tipos gerais ${ }^{306}$ :

Circunvenção é um ataque que decorre do acesso obtido por meios técnicos aos dados e recursos de operação básica do sistema biométrico, alterando ou furtando os modelos armazenados ou corrompendo sistemas decisórios. É o mais difícil de ser tecnicamente efetuado por implicar um grande conhecimento de todo o sistema a ser fraudado e por ser mais facilmente identificável.

Contaminação é o uso de informações biométricas legítimas para acessar o sistema, seja por capturar os dados a revelia (p.ex. gravar a voz do indivíduo sem consentimento) seja utilizando os dados legítimos em um sistema diferente daquele para o qual foram originariamente fornecidos (impressão digital para acesso em um local utilizada em uma ATM).

Fraude ou coerção é a participação voluntária ou forçada do detentor da característica biométrica no ataque ao sistema. Sua realização independe da indução de alterações no sistema operacional.

\footnotetext{
${ }^{305}$ Andy ADLER, Biometric system security in Handbook of biometrics, p. 382.

${ }^{306}$ D. MALTONI et al, Handbook of fingerprint recognition.
} 
Recusa de serviço (Denial of Service) é um ataque que visa a interrupção do acesso do sistema biométrico por meio de sobrecarga do sistema seja por excesso de dados fornecidos, seja por dados corrompidos que forcem a lentificação de sua desempenho. O objetivo é forçar a utilização de um outro sistema de identificação mais exposto a fraudes (e.g. falhas na identificação por impressões digitais que levem a utilização de senhas).

Repúdio é a negação do acesso ao sistema pelo fraudador sob qualquer alegação (p.ex. afirmação de que seus dados originais foram roubados ou alterados no sistema por "hackers").

Os sistemas biométricos oculares apresentam algumas vantagens contra alguns desses ataques. A contaminação é mais difícil de ser realizada nos sistemas biométricos oculares já que a captação da imagem ocular para processamento biométrico é altamente dependente da colaboração do seu doador e das condições ambientais de sua obtenção, o que diminui a possibilidade de obter o IrisCode de alguém sem que o usuário perceba. Além disso, os sistemas biométricos requerem a presença do olho vivo e não apenas de sua imagem. A recusa de serviço é evitada pelo pequeno tamanho do modelo biométrico ocular, possibilitando uma grande facilidade de seu processamento sem sobrecarregar o sistema.

Ainda assim, os sistemas biométricos oculares compartilham com todos os outros sistemas a possibilidade de ataques por circunvenção, fraude, coerção e repúdio, impondo-se assim a necessidade de monitoração constante desses sistemas por operadores habilitados para minimizar os riscos que esses ataques acarretam.

Uma forma de fraude é especialmente importante nos sistemas biométricos oculares. É a utilização de artifícios para impossibilitar a captação de imagens de qualidade para serem processadas. Como a qualidade da imagem é a mais importante limitação ao sistema biométrico ocular, o usuário de má-fé pode dificultar a obtenção de qualquer imagem aceitável para não ser submetido a esse método de identificação. È um tipo misto de repúdio e de falta de serviço. Por exemplo, a não colaboração com a fixação ocular, uso de lentes de contacto, fechamento total ou parcial dos olhos durante o teste, alteração de cílios e outros artifícios podem impedir a biometria ocular e forçar o uso de outros métodos menos seguros. Essa possibilidade de fraude tem sido combatida por meio do aperfeiçoamento do equipamento utilizado e pela monitoração da operação da biometria. 
Um ponto importante na segurança da biometria é a garantia da privacidade do sistema. Os dados armazenados não devem ser franqueados a pessoas não autorizadas. Esses dados, idealmente, não devem permitir a reconstituição do caractere biológico que os gerou, permitindo assim, a possível produção de um modelo para utilização fraudulenta ou a revelação de informações pessoais a serem preservadas.

Quanto à possibilidade de reconstrução do modelo de íris ou retina que gerou o modelo biométrico, os sistemas oculares estão entre os mais seguros, sendo extremamente difícil reproduzir o aspecto da superfície da íris a partir de seu irisCode, em razão dos algoritmos necessários para sua formulação apresentarem grande variabilidade matemática.

O sistema biométrico deve ser tão eficaz no reconhecimento quanto na negação da identidade. Essas habilidades dependem não só dos equipamentos e da técnica, mas também das características físicas dos usuários que podem ser classificados quanto à facilidade de serem reconhecidos, confundidos ou de fraudarem o sistema biométrico. $\mathrm{Na}$ verdade, quanto maior a unicidade e classificabilidade de um método de identificação, menor a chance de ocorrerem falhas dependentes das características individuais do traço biométrico.

Doddington et al. classificam os usuários em 4 tipos: os carneiros, ovelhas, cabritos, e lobos. Os carneiros constituem a maioria podendo ser facilmente identificados ou não-reconhecidos pelo sistema. Os cabritos são a minoria de difícil reconhecimento causando o aumento da taxa de falsa rejeição (FRR). As ovelhas são os indivíduos facilmente imitáveis levando ao aumento da taxa de falsa aceitação (FAR). Os lobos são os indivíduos facilmente confundidos com outros também levando a um aumento da taxa de falsa aceitação. A identificação das ovelhas e dos lobos de um dado sistema é uma preocupante fonte de fraudes para qualquer sistema biométrico, não estando os sistemas oculares isentos ou especialmente vulneráveis a esses problemas ${ }^{307}$.

Em resumo, ao analisarem-se os dados de confiabilidade e segurança da biometria ocular pode-se dizer que é um método que apresenta confiabilidade e segurança suficientes para sua utilização na perícia judicial da identidade, desde que observadas as condições de sua utilização.

${ }^{307}$ G. DODDINGTON et al. Sheep, goats, lambs and wolves: analysis of individual differences in speaker recognition performance in Proceedings of the International Conference on Auditory-visual speech processing, Sidney, Australia, 1998. 
Serão vistos, a seguir, alguns aspectos da perícia judicial utilizando e avaliando a biometria das estruturas oculares. 


\section{CAPÍTULO VIII. PRIVACIDADE E BIOMETRIA OCULAR}

A crescente utilização das técnicas de identificação biométricas após os atentados de 11 de setembro tem causado críticas de entidades de defesa dos Direitos Humanos. E, neste aspecto, a biometria ocular acompanha as demais modalidades biométricas, não apresentando especificidades importantes. Alguns autores temem a utilização universal da biometria na identificação e acompanhamento das pessoas invadindo sua privacidade e desrespeitando assim um direito personalíssimo.

Definem-se direitos da personalidade como os relacionados à pessoa, como o direito ao seu corpo, ao seu nome, sua imagem e qualquer outro aspecto referente à sua identidade ${ }^{308}$. São direitos tidos como irrenunciáveis, sendo garantidos na Constituição em seu artigo $5^{\circ}$, em diversos incisos. Os direitos da personalidade fundamentam-se na dignidade humana, e seu reconhecimento fez parte da evolução histórica rumo à promoção da dignidade individual de cada homem como meta e limite para o Estado.

$\mathrm{O}$ direito à privacidade é o que garante a cada indivíduo a discricionariedade quanto à divulgação de informações a seu respeito. Cada ser humano é digno porque tem autonomia de decisão e ação, incluído nessa autonomia o controle dos dados de sua vida e corpo. O fornecimento dos mesmos só pode ocorrer pela vontade e no interesse de seu possuidor. É evidente, no entanto, que como acontece em relação a qualquer direito, admitem-se situações em que direitos superiores, por exceção, tomem lugar do direito à privacidade, permitindo a revelação de dados privados do indivíduo.

O fornecimento de dados biométricos para identificação pode ameaçar a privacidade dos que os fornecem. Inicialmente, porque esses dados serão armazenados e custodiados por terceiros. O banco de dados que os armazenam são passíveis de serem acessados por sistemas informáticos fraudadores que podem copiar ou alterar os dados iniciais. A utilização das informações biométricas que, em última análise, são características biológicas, pode escapar dos limites iniciais de identificação, servindo a outros propósitos. Outras instituições, inclusive governamentais, podem utilizar os modelos biométricos em cenários inicialmente diferentes daqueles para os quais foram cedidos, permitindo acesso indevido a dados biológicos de terceiros.

\footnotetext{
${ }^{308}$ Carlos Alberto BITTAR, Os Direitos da personalidade, Forense Universitária.
} 
A principal conseqüência da violação ao direito à privacidade é a ameaça que a perda da privacidade traz à autonomia do cidadão. Sistemas de identificação que prescindem da participação voluntária do indivíduo já são hoje possíveis, especialmente pela biometria da face. As biometrias da íris e da retina também estão sendo aperfeiçoadas para identificar indivíduos à distância, como em alguns filmes de fícção científica ${ }^{309}$. Essa forma de identificação pode limitar o direito de ir e vir de forma significativa.

Em uma sociedade em que se admite esse controle, a relação entre cada indivíduo e o Estado torna-se diferente. A confiança entre esses dois agentes desenvolvese em outro patamar. Tal efeito colateral dos sistemas biométricos é o mais temido, sendo a principal crítica à sua utilização ampliada.

Para garantir que técnicas biométricas não permitam a violação da privacidade, algumas medidas foram adotadas. Inicialmente, os bancos de dados biométricos obedecem a uma rigorosa política de guarda de sigilo, semelhante às existentes em outros bancos de dados. A quebra desse sigilo sujeita os responsáveis às penas da lei.

Salvaguardas técnicas de segurança foram desenvolvidas para preservar esse sigilo. Por exemplo, os dados armazenados obedecem a algoritmos criptografados para evitar sua decifração por invasores do sistema ("hackers"). Esses mesmos dados, como já visto, não permitem a reconstituição anatômica e funcional do órgão que descrevem, i.e., o IrisCode não permite a reconstrução da imagem da íris que o gerou. Os dados biométricos, além disso, não incluem informações orgânicas além daquelas referentes à identificação, não sendo possível a partir deles, diagnosticar doenças ou deficiências dos usuários.

Os modelos biométricos podem conter outras informações adicionais, como nome do indivíduo, gênero, idade e outros dados pessoais. Se esses dados secundários contiverem informações que os usuários não queiram revelar, essas informações podem ser apagadas ou alteradas e já existem algoritmos para essas operações para a maioria dos sistemas biométricos ("cancelable biometrics").

$\mathrm{Na}$ formulação de um sistema biométrico ideal é necessária uma combinação de opacidade e transparência. A opacidade refere-se à guarda de sigilo e à cadeia de confidencialidade que os bancos de dados biométricos tem que observar. A transparência é

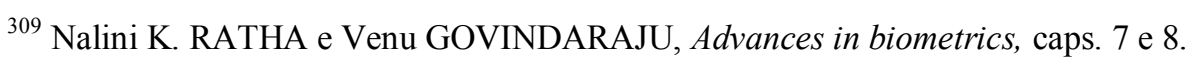


a possibilidade de acesso a seus dados que deve ser disponibilizada a todos os usuários. Em outras palavras, tanto os que podem ter acesso quanto o que deve estar acessível deve ser controlado primordialmente pelo indivíduo usuário do sistema ${ }^{310}$.

No Brasil, o habeas data constitui-se um remédio constitucional para que os indivíduos controlem esses bancos de dados, especilamente em caso de risco de alterações indevida em seus dados.

Por outro lado, não se pode esquecer que os sistemas biométricos são também poderosas armas para a defesa da privacidade dos indivíduos. A verificação mais precisa da identidade protege os recursos financeiros e pessoais de todos contra os que os ameaçam. Exemplos dessas situações são facilmente encontrados no acesso a recursos financeiros sob guarda de instituições financeiras, no controle da entrada de pessoas em certos lugares, na proteção contra a utilização não autorizada de equipamentos e etc.

No plano internacional, o 11 de setembro motivou o surgimento de medidas de controle de fronteiras e de suspeitos mais rigorosas, geralmente realizadas com técnicas biométricas. Alguns desses sistemas têm inclusive utilizado biometria da íris. A resistência a essas medidas, iniciada por grupos de proteção dos direitos humanos tem sido contornada pela promulgação de leis ("Patriotic Act") ou por decisões judiciais que as interpretam como constitucionalmente válidas especialmente nos Estados Unidos.

É, assim, preocupante que a tecnologia biométrica seja utilizada como forma de violação de direitos humanos tão duramente conquistados. Fruto exclusivo do avanço tecnológico contemporâneo, a biometria deve primordialmente promover a segurança dos indivíduos em todos os seus aspectos, inclusive frente às forças do Estado, quando estas os ameaçam.

Por essa razão, embora as leis hoje em vigor permitam de certa forma coibir os abusos, leis específicas sobre o uso de métodos biométricos devem ser promulgadas para que o controle de sua formulação e utilização seja eficaz e abrangente, protegendo a todos dentro dos limites de um Estado Democrático de Direito.

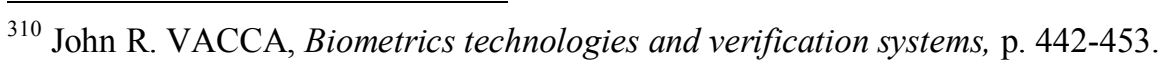




\section{CONCLUSÃO}

O reconhecimento da identidade do homem é um direito que decorre da dignidade humana reconhecida na individualidade de cada pessoa pelas sociedades democráticas. No passado, identificar confundia-se com estigmatizar como forma de punição ou de exclusão. Mesmo recentemente, as técnicas de identificação prestavam-se principalmente ao controle social dos marginalizados ou excluídos, sendo operadas em sua maioria por forças policiais ou de repressão. É importante conhecer o histórico das técnicas de identificação para evitar que as eficientes técnicas atuais não sejam utilizadas em atentados mais graves à dignidade humana.

As técnicas de identificação biométricas são automatizações de técnicas utilizadas no passado. Essa automatização tornou-se possível com o desenvolvimento dos recursos eletrônicos e da informática. A íntima ligação entre informática e biometria reflete-se nos problemas sobre os quais os estudiosos da biometria se debruçam, que são, em sua maioria, relacionados aos equipamentos e programas informáticos utilizados. Por essa razão, a maior parte dos especialistas na área são especialistas em informática e matemática aplicada. É necessário que os médicos legistas e operadores do Direito voltem sua atenção às possibilidades e limites dessas técnicas para disciplinar seu uso em aplicações jurídicas e civis.

Uma das preocupações é com a utilização de sistemas de identificação informatizados em atividades que violem o Direito à Privacidade. A eficiência dos novos equipamentos permite, de fato, diversas formas novas de violação à privacidade $\mathrm{e}$ intimidade das pessoas. Neste ponto, os operadores do Direito devem procurar conhecer as possibilidades abertas por essas novas tecnologias a fim de discipliná-las por meios legais capazes de conter sua utilização inadequada.

As técnicas biométricas utilizam traços biológicos ou comportamentais captados por meios eletrônicos. Dados informáticos desses traços denominados "templates" ou modelos - são armazenados em um banco de dados informatizado e posteriormente comparados com dados de amostras semelhantes. A finalidade dessa comparação é a demonstração da semelhança dos modelos novos com algum dos armazenados ou a demonstração de que nenhum dos modelos armazenados corresponde à nova amostra obtida. Com esse procedimento, é possível demonstrar a correspondência ou a 
incongruência entre os modelos e assim, afirmar estatisticamente a identidade ou nãoidentidade de alguém. É importante ter em mente que uma resposta biométrica é estatisticamente verdadeira, mas não uma demonstração inequívoca da identidade de alguém. No entanto, essa resposta probabilística está mais afinada com as atuais tendências das provas periciais em juízo, que hoje se baseiam em dados estatísticos e não em respostas do tipo sim ou não.

Há diferentes técnicas biométricas diferenciando-se pelo traço biométrico utilizado. Há a biometria das impressões digitais, da face, da geometria da mão, da íris, da retina, das veias da mão, do andar, do ritmo de digitação, da voz, da geometria da orelha e um número cada vez maior de novas tecnologias. Cada uma delas tem encontrado maior ou menor aplicação prática por razões econômicas e pragmáticas.

Neste trabalho, foram estudadas as técnicas de biometria que utilizam traços oculares da íris e da retina para identificação humana. Demonstrou-se que no momento somente a biometria da íris tem utilizações práticas, ficando a biometria da retina somente como um registro histórico de uma técnica que começa a ser agora retomada.

A biometria da íris é precisa, confiável e com desempenho suficientemente eficiente para recomendá-la como meio de verificação da identidade em universos com grande número de indivíduos registrados. Isso ficou demonstrado em sua principal utilização no momento que é o controle de entrada de imigrantes em aeroportos. Essa utilização da biometria da íris propiciou o impressionante número de 200 bilhões de comparações de modelos biométricos com grande taxa de acerto. Para essa finalidade, a biometria da íris demonstrou superioridade de desempenho inconteste em comparação com as outras técnicas biométricas. Suas desvantagens são seu custo elevado, maior dificuldade de operação e necessidade de controle restrito das condições de operação com o equipamento atual.

A biometria da íris apresenta alguns fatores de imprecisão que devem ser conhecidos para seu controle e prevenção. Há também preocupações quanto à segurança em sua operação e quanto à guarda dos dados armazenados no sistema biométrico. Como sistema informático, os ataques que os sistemas biométricos sofrem são os mesmos a que todas as redes de computadores estão sujeitos. A segurança dos sistemas biométricos confunde-se, portanto com a segurança informática. 
A Biometria da íris, por fim, demonstrou ser suficientemente confiável e segura para que sua utilização no sistema jurídico como método de identificação seja aceita sem reservas ao lado de outras técnicas já consagradas. Cabe, evidentemente aos peritos avaliar se o método seguido foi tecnicamente válido, dentro das normas de eficiência e segurança já demonstradas, para que as evidências trazidas pela aplicação do método biométrico da íris sejam de valor para a apreciação em juízo. 


\section{ANEXO - GLOSSÁRIO}

Ácidos nucléicos Compostos químicos encontrados no núcleo e no citoplasma das células cuja função principal é armazenar informações hereditárias e controlar o funcionamento do metabolismo celular.

Alelo Cada um dos tipos de um determinado gene.

Algoritmo Seqüência de operações matemáticas ou informáticas que comanda a execução de uma tarefa.

API (Aplication programming interface) Interface de programação de aplicativos Conjunto de rotinas e padrões oferecidos por um determinado programa informático para utilização de algumas de suas funções por outros programas.

Astigmatismo Erro refracional causado pela irregularidade das curvaturas da córnea que causam distorção das imagens próximas e distantes do olho.

Bastonetes Células fotorreceptoras encontradas na retina responsáveis pela visão em condições de menor luminosidade. São também responsáveis pela visão em tons de cinza (preto e branco).

“Bits” Menor unidade de informação computacional. É a abreviação de "binary digit". Pode ser de dois tipos 0 e 1 .

Bulbo ocular Globo ocular na nova nomenclatura anatômica.

“Bytes” Conjunto de 8 bits, utilizado em computação por razões práticas.

Calcâneo Principal osso do calcanhar.

Cariótipo Conjunto de cromossomos de uma célula, visualizado durante a divisão celular.

Carpo A região do punho que é composta de 8 ossos.

CCD ("Charged-coupled device"). Dispositivo que capta imagens e as converte em sinais elétricos para serem processados como imagens fotográficas ou de vídeo. Corresponde ao filme fotográfico utilizado em uma câmera convencional. As câmeras digitais possuem este dispositivo para captação e posterior digitalização das imagens.

Células adiposas Células que armazenam gordura.

Células gliais Células componentes do tecido nervoso que servem à sustentação, defesa e nutrição dos neurônios.

Células neurais Neurônios, que são as células que realizam as atividades neurológicas.

Código genético Seqüência de nucleotídeos (porções de ácidos nucléicos) que codificam as reações do metabolismo das proteínas e da hereditariedade de cada célula. 
Cones Células fotorreceptoras da retina que respondem a luminosidade mais intensa, sendo responsáveis pela visão de cores.

Corióide Túnica vascular do olho que nutra a retina e tem porções especializadas como a íris e o corpo ciliar. Era denominada pela antiga terminologia coróide.

Corpo ciliar Porção da corióide que produz o humor aquoso e sustenta a lente.

Corpo vítreo Tecido protéico gelatinoso e transparente que preenche o bulbo do olho.

Corte sagital Plano que divide o corpo em duas metades verticalmente, a metade direita e a esquerda.

Criptografia Técnica de escrever em forma secreta por meio de um código.

"Denial of service" (DoS) Funcionamento inadequado de um sistema informático fraudulentamente provocado, seja por excesso de informações apresentadas, seja por informações incorretas que não podem ser processadas.

Digitalização Técnica de transformar dados de algo em linguagem informática para seu processamento por sistemas informáticos.

Diodo Dispositivo produzido com a utilização de semicondutores para controlar a passagem de elétrons em determinados sistemas.

DNA/RNA Cada um dos dois tipos de ácidos nucléicos, com funções diferentes dentro do mecanismo de vida celular.

Dopagem Sistema de produção de materiais semicondutores que permite o controle da passagem dos elétrons por esses materiais apenas sob determinadas condições.

EER Taxa de igualdade entre a taxa de falsa aceitação (FAR ou FMR) e a de falsa rejeição (FRR ou FNMR).

“Enrollment” Registro de dados em um sistema informático.

Erro de refração Alteração de foco dos sistemas ópticos do olho que causa visão dimnuída por borramento das imagens que chegam à retina. São de três tipos miopia, hipermetropia e astigmatismo.

Esclera Túnica fibrosa do bulbo ocular de coloração branca visível ao redor da córnea.

Estimativa de borda circular (circular boundary estimation) Operação de matemática computacional destinada a definir dados circulares de uma imagem digitalizada.

Estroma Tecido de suporte de um órgão qualquer.

$\boldsymbol{F A R / F M R}$ Taxa de falsa aceitação de um modelo biométrico (false acceptance rate ou false match rate).

FBI Federal Bureau of Investigation, o equivalente americano da Polícia Federal Brasileira. 
Fenótipo Apresentação final de um dado caractere geneticamente determinado. Esse aspecto é particularmente influenciado por fatores não genéticos ou ambientais.

Ferrete Sistema de marcação cutânea por um ferro incandescente.

“Flash memory" Sistema de memória informática que armazena dados sem a necessiadade de fonte de energia.

Flebográfico Registro de imagem de um sistema venoso.

Fotodiodo Diodo responsivo à energia luminosa.

Fotografia sinalética Fotografia padronizada para permitir a comparação entre duas fotos obtidas em momentos diferentes.

Fotorreceptores Células sensíveis à energia luminosa.

“Frameworks" Em português "arcabouço". Refere-se a uma forma de integração entre diferentes programas informáticos baseada em um trabalho de abstração genérico que utiliza partes comuns a todos eles.

$\boldsymbol{F R R / F N M R}$ Taxa de falsa rejeição de um sistema biométrico (false rejection rate ou false non-match rate).

FTER Taxa de falha no arquivamento ou obtenção do caractere biométrico (failure to enroll rate).

Gametas Cada uma das células reprodutivas, espermatozóide e óvulo.

Genes Seqüências de ácidos nucléicos do núcleo das células agrupados em cromossomos que determinam características dos indivíduos podendo transmiti-las a seus descendentes. Também controlam o metabolismo e estrutura celular por meio da produção de proteínas.

Genótipo Conjunto de características genéticas de cada indivíduo.

Glaucoma Doença ocular crônica que pode levar a perda da visão e que é associada ao aumento da pressão intra-ocular.

“Hackers" Invasores de sistemas informáticos que procuram perturbar sua operação ou roubar dados e recursos controlados pelo sistema vitima da invasão.

Hemácias Glóbulos vermelhos do sangue.

Hipermetropia Erro refracional que ocasiona dificuldade visual de imagens próximas do olho sem perturbar a visão dos objetos que estão mais distantes.

Humor aquoso Líquido que preenche as câmeras anteriores do olho.

Iridociclite Inflamação da íris e do corpo ciliar. 
Lábio leporino Lábio superior que apresenta uma fenda vertical resultado de uma alteração genética e que se expressa desde o nascimento. O palato também pode estar fendido.

“Lock-ins” Barreiras de entrada de novos concorrentes no mercado que caracterizam um monopólio.

Mácula Porção central e de maior acuidade visual na retina, ponto de fixação da visão.

"Match Server" Computador utilizado para realizar a comparação entre os modelos biométricos apresentados e os armazenados no sistema.

“Matching” Comparação entre o modelo armazenado e o apresentado ao sistema biométrico. Pareamento.

Melanossomos Vesículas intracelulares que armazenam pigmentos.

Metatarso Porção da palma da mão em que se situam diversos ossos que se articulam com os dedos.

Mídia São os meios físicos de suporte de arquivos informáticos. Ex.: CDs, DVDs, PenDrives e etc.

Miopia Erro de refração que causa turvação das imagens de objetos distantes do olho sem perturbar a imagens dos que estão próximos.

Musculatura ocular extrínseca Músculos responsáveis pelos movimentos dos olhos.

Musculatura ocular intrínseca Músculos internos do olho que são responsáveis pela focalização das imagens na retina ao modificarem a curvatura da lente (cristalino).

Músculo estriado Músculo dos movimentos voluntários. Recebe esse nome pelo seu aspecto microscópico.

Ora serrata Porção intermediária da corióide em que ocorre a inserção da retina e do vítreo.

Órbita Cavidades ósseas do crânio que abriga o bulbo do olho.

Palato Céu da boca.

$\boldsymbol{p B}$ Pares de bases. São as pares de nucleotídeos que formam o DNA.

Pelve Região da bacia onde se encontram órgãos do sistema gênito-urinário.

"Pen drive” Dispositivo de armazenamento portátil de arquivos informáticos que utiliza os sistemas "flash memory" e "USB". Seu nome deriva de seu aspecto semelhante à uma caneta.

Pia-máter Camada fibrosa que envolve o sistema nervoso central e permite seu contato com as estruturas que o envolvem.

“Pixel” Abreviação de "Picture element" pontos de uma imagem digitalizada. 
Polimorfismo Propriedade de genes de apresentarem diversos tipos diferentes, fazendo com que o caractere possa ter grandes variações.

Pólo anterior Porção anterior do olho formada pela córnea, a íris e a lente.

Pólo posterior Porção posterior do olho onde se encontra o centro da retina e o disco óptico.

“Polymerase chain reaction” (PCR) Técnica de polimerização de DNA que permite a multiplicação das cadeias das amostras para facilitar sua manipulação.

Processador Equipamento informático que processa dados, computador.

Processo estocástico Processo que ocorre seguindo princípios aleatórios.

Retina Túnica ocular sensível à luz que recobre o interior do bulbo ocular.

Saturnismo Doença causada pelo acúmulo de chumbo no organismo.

Scanner Equipamento destinado a examinar arquivos ou imagens e digitalizar os dados para um programa informático.

Segmentação Operação que isola parte de uma imagem digitalizada do total captado.

Semicondutores Materiais que conduzem eletrôns apenas sob determinadas condições.

Servidor Computador central em uma rede de computadores.

Silicose Doença causada pelo acúmulo de sílica no organismo, comum em determinados trabalhadores.

Sistema de histocompatibilidade Conjunto de proteínas geneticamente determinadas existentes na superfície de leucócitos e demais células do organismo que serve para reconhecimento do que é próprio ou estranho a ele.

Sistema HLA Um dos sistemas de histocompatibilidade.

Sistema NIR Luz que pode ser utilizada em equipamentos que iluminam o olho para captação de imagens ou exames sem lesar as estruturas oculares (near infrared)

Sistemas Sangüíneos (ABO, $R \boldsymbol{h}, \boldsymbol{M N})$ Proteínas da superfície das hemácias e algumas outras células, geneticamente determinadas que são responsáveis pelo sucesso ou pela rejeição das transfusões sangüíneas.

STR Seqüência curta de repetições de ácidos nucléicos utilizados em testes de DNA (short tamdem repeat).

Tecido conectivo Tecido que preenche estruturas corporais.

“Template” Modelo ou gabarito de algo que é possível de ser armazenado como dados informatizados. 
Trato nervoso Feixe de fibras nervosas que têm mesma origem, terminação e função.

Transformação discreta de Fourrier (FFT) Equações matemáticas complexas que utilizam derivadas e integrais utilizadas na transformação de dados informáticos.

USB (“Universal serial bus") Sistema de interface universal utilizado na conexão entre equipamentos e computadores.

Visão computacional Ciência que estuda o processamento de imagens digitalizadas em informática, visando extrair informações das mesmas.

VNTR Seqüência de nucleotídeos utilizados nos testes de identificação pelo DNA (variable number tandem repeat) 


\section{BIBLIOGRAFIA}

ABBAGNANO, Nicola (Ed.). Dicionário de filosofia. Tradução de Alfredo Bosi. 2 ed.. São Paulo: Martins Fontes, 1998.

ALCÂNTARA, Hermes Rodrigues de. Perícia médica judicial. Rio de Janeiro: Editora Guanabara 2, 1982.

ALMEIDA JR. Antônio Ferreira; COSTA Jr. João Batista de O. Lições de Medicina Legal. 14 ed. São Paulo: Cia. Editora Nacional. 1977.

ALVES, Alaôr Caffé. Lógica: pensamento formal e argumentação: Elementos para o discurso jurídico. Bauru: Edipro, 2000.

AMERICAN ACADEMY OF OPHTHALMOLOGY. Fundamentals and principles of ophthalmology. (Basic and clinical science course). Section 2. 1996-1997. San Francisco:AAO, 1996.

External disease and cornea. (Basic and clinical science course). Section 8. 1996-1997. San Francisco:AAO, 1996.

BAMSHAD, Michael J.; OLSEN, Steve E. Ambigüidades que limitam uma definição de raça. Scientific American Brasil $\mathrm{n}^{\mathrm{o}}$ 20, janeiro de 2004, Disponível em http:// www2.uol.com.br/sciam/conteudo/materia/matéria_38html. Acesso em 23 de abril de 2004.

BAUMAN, Zygmunt. Identidade. Rio de Janeiro: Jorge Zahar Editor, 2005.

BITTAR, Carlos Alberto. Os direitos da personalidade. Rio de Janeiro: Forense Universitária, 1995.

BOCK Ana Maria. B.; FURTADO Odair; Maria de Lourdes T. TEIXEIRA. Psicologias. Uma introdução ao estudo de psicologia. 13a ed.. São Paulo: Ed. Saraiva, 2005.

BONACCORSO, Norma. Análise Forense de DNA. Disponível em http://www.peritocriminal.com.br/dnaforense.htm. Acesso em 28/04/2007.

BONNET, Emílio Frederico Pablo. Medicina legal. 2 ed. Buenos Aires: Lopez Libreiros, 1993. 
BRAUNWALD, Eugene et al. Harrison's manual of medicine. 15 ed. Boston: McGraw-Hill, 2002.

BUSACCA, Archimede. Manuel de biomicroscopie oculaire. Paris: Editions Doin, 1966.

CABANIS, E.A.; LeGALL J.Y.; ARDAILLOU R. Personal identification with biometric and genetic methods. Bull Acad. Natl. Med. 2007 Nov; 191(8); 1779-82. French

CARVALHO, Maria Rosário G. de. Breves reflexões suscitadas pelo artigo "Política de cotas raciais, os 'olhos da sociedade' os usos da antropologia: o caso do vestibular da Universidade de Brasília (UNB)" Horizonte antropológicos ano 11, nº 23, p. 265-267, jan/jun 2005.

CASTELLS, Manuel. O poder da identidade. A era da informação: economia, sociedade e cultura. Vol. 2. 6 ed. São Paulo: Editora Paz e Terra, 2008.

CHEDIAK, Karla. O problema da individuação na biologia à luz da determinação da unidade de seleção natural Scietle studia. Vol. $3 \mathrm{n}^{\circ} 1$ p.67-78, 2005. Disponível em http:// www.scientiaestudia.org.br/revista/PDF/3.01.03.pdf. Acesso em 23 de março de 2007.

COMPARATO, Fábio Konder. A afirmação histórica dos direitos humanos. São Paulo: Ed. Saraiva, 1999.

COMTE-SPONVILLE, André. Dictionnaire philosophique. Paris: PUF, 2001.

CROCE, Delton; CROCE JR., Delton. Manual de medicina legal. $5^{\text {a }}$ ed. Revista e ampliada. São Paulo: Ed. Saraiva, 2004.

DANTAS, George Felipe L. Os novos passaportes biométricos. Disponível em http://www.fenapef.org.br/htm/com_noticias_exibe.cfm?Id=45788. Acesso em 20 de janeiro de 2008.

DASS, S.C.; ZHU, Y.; JAIN, A.K. Validating a biometric authentication system: sample size requirements. IEEE Trans. Pattern Anal. Mach. Intell. 2006 Dec; 28(12) 1902-319.

DAUGMAN, John. How iris recognition works. Universidade de Cambrigde, 2004. Disponível em www.CL.cam,uk/users/jgd1000. Acesso em 19 de dezembro de 2007.

Probing the uniqueness and randomness of IrisCodes: results from 200 billion iris pairs comparisons.

Disponível em 
http://www.cl.cam.ac.uk/ jgd1000/ProcIEEEnov2006Daugman.pdf. Acesso em 14 de novembro de 2008.

New methods in iris recognition. IEEE Trans System Man. Cybern. B. Cybern. 2007 Oct; 37(5): 1167-75 Review

DODDINGTON, G.; LIGGETT W.; MARTIN, A.; PRYBOCKI, N.; REYNOLDS, D. G. Sheep, goats, lambs and wolves: an analysis of individual differences in speaker recognition performance in Proceedings of the International Conference on Auditory-visual speech processing, Sidney, Australia, 1998.

DUANE, Thomas D.; JAEGER, Edward A. Clinical ophthalmology. rev.. Philadelphia: Harper \& Row, 1984.

DEL-CAMPO, Eduardo Roberto Alcântara. Medicina legal. (Coleção curso e concurso). 2 Ed. rev. e atual. São Paulo: Ed. Saraiva, 2006.

DESSIMOZ D.; RICHIARDI J.; CHAMPOD C.; DRYGAILO A. Multimodal biometrics for identity documents (MBioID). Forensic Sci. Int. 2007 Apr 11;167(2-3);154-9.

EPSTEIN, Robert. Fingerprints meet Daubert: the myth of fingerprint "science" is revealed. Disponível em http://www.fd.org/Publications?SpecTop/fingerprintlawreview.pdf . Acesso em 25 de janeiro de 2008.

FÁVERO, Flamínio. Medicina legal. 9 ed.. São Paulo: Livraria Martins Editora, 1973.

FEDERMAN, James L. et al. Retina and vitreous v. 9 in Textbook of ophthalmology, electronic edition. Boston: Mosby, 1994.

FIGINI, Adriano Roberto da Luz et al. Identificação humana. 2 ed. Campinas: Editora Milllenium, 2003.

NOVA ENCICLOPÉDIA ILUSTRADA FOLHA. São Paulo: Folha da Manhã, 1996.

GARCÍA-PABLOS DE MOLINA; Antonio; GOMES, Luiz Flávio. Criminologia. 4 ed. revista, atualizada e ampliada. São Paulo: Revista dos Tribunais, 2002.

GOFFMAN, Erving. Estigma notas sobre a manipulação da identidade deteriorada. 4 ed.. Rio de Janeiro LTC S.A. 1988. 
A representação do eu na vida cotidiana. 14 ed.. Petrópolis: Vozes, 1975.

GOMES, Hélio. Medicina legal. 33 ed., rev. e ampl. Rio de Janeiro: Freitas Bastos Editora, 2004.

HOLLINGSWORTH, Karen; BOWYER, Kevin; FLINN, Patrick. Pupil dilation degrades iris biometrics performance ScienceDirect. Disponível em http://www.sciencedirect.com/science?_ob=ArticleURL\&_udi=B6WCX-4T708F3$1 \&$ user $=10 \&$ rdoc $=1 \&$ fmt $=\&$ orig $=$ search\& sort $=\mathrm{d} \&$ view $=\mathrm{c} \&$ version $=1 \&$ urlVersion $=$ $\underline{0 \& \text { userid }=10 \& \mathrm{md} 5=\mathrm{d} 6 \mathrm{ceba} 1 \mathrm{de} 4 \mathrm{e} 30 \mathrm{fe} 17 \mathrm{f} 79 \mathrm{f0} 1213 \mathrm{fc} 4078 .}$. Acesso em $14 \mathrm{de}$ novembro de 2008.

BRASIL Instituto Nacional de identificação. Processos de identificação. Disponível em http://www.dpf.gov.br/centrais/ini/ini_continuacao.htm. Acesso em 24 de março de 2007.

INTERNATIONAL BIOMETRIC GROUP. Independent testing of iris recognition technology final report, may 2005. Disponível em http://www.biometricgroup.com/reports/public/reports/ITIRT_report.htm. Acesso em $14 \mathrm{de}$ novembro de 2008.

IRITECH INCORPORATED. Biometric technology. Disponível em http://www.iritech.com/index.html. Acesso em 04 de janeiro de 2008.

JAIN, Anil K., Technology: biometric recognition. Nature 2007 Sep 6; 449 (7158): 38-40.

JAIN, Anil K.; FLYNN, Patrick; ROSS, Aun (Editors) A. Handbook of biometrics. New York: Springer-Science+Business Media, 2008.

JAIN, Anil K.; BOLLE Ruud; PANKATI, Sharath (Edit.) Biometrics personal identification in networked society. London:Springer, 1999.

JOBIM, Luiz Fernando; COSTA, Luís Renato da Silveira; SILVA, Moacyr da. Identificação Humana. Volume II. Campinas:Editora Millenium, 2006.

JUNQUEIRA, Luiz Carlos Uchoa; CARNEIRO, José. Histologia básica. 10 ed.. Rio de Janeiro: Guanabara-Koogan, 2004. 
KANG. B.J.; PARK, K.R. Real-time image restoring for iris recognition systems. IEEE Trans System Man. Cybern. B. Cybern. 2007 Dec 37(6); 1555-66.

KANSKI, Jack J. Clinical ophthalmology a systemic approach. 5 Ed. Oxford: ButterworthHeinemann. 1995.

L.G. Electronics. "Iris recognition”. Cranbury: Iris Technology Division, 2003. Disponível em http://www.lgiris.com LG Íris Recognition Technology. Acesso em 03 de janeiro de 2008.

LALANDE, André. Vocabulário técnico e crítico de filosofia. Tradução de Fátima Sá Correia et al. 3 ed.. São Paulo: Martins Fontes, 1999.

LETTICE, John. UK airport iris biometric system flunks its exam. Disponível em http://www.theregister.co.uk/2007/01/11/project_iris_evaluation_report/. Acesso em $14 \mathrm{de}$ novembro de 2008.

MALTONI, Davide.; MAIO, D.; JAIN Anil .K.; PRABHAKAR Saliu. Handbook of fingerprint recognition. Londres: Springer-Verlag, 2003.

MARANHÃO, Odon Ramos. Curso básico de medicina legal. 8 ed.. São Paulo: Ed. Malheiros, 2005.

MOENSSENS, Andre A. "The reability of fingerprinting identification: a case report". Disponível em http://www.forensic-evidence.com/site/ID/pollak2002.html. Acesso em 25 de agosto de 2007.

MOSES, Robert A. Adler's fisiología del ojo Aplicación clínica. 8 ed. Trad. Diana A.F. de Camardelli. Buenos Aires:Editorial Médica Panamericana, 1988.

NAU, J.Y. The heavy threat of human biometry (1) Rev Méd Suisse 2007 Jun 13:3 (115); 1547

NAVARRO, Pedro Luis Kantek Garcia. “AFIS". Disponível em http://www.pr.gov.br/batebyte/edicoes/2001/bb111/afis.htm. Acesso em 25 de agosto de 2007.

NOVER, Arno. O fundo do olho. Técnica de exploração e achados característicos. Tradução de Hildegard T. Buckup. 4 ed. rev. e ampl. São Paulo: Manole, 1981. 
MATSUSHITA ELETRIC INDUSTRIAL CO. Biometrics. Disponível em http://www.panasonic.com/business/security/products/biometrics.asp. Acesso em 04 de Janeiro de 2008.

OKI ELETRIC INDUSTRY. Irispass. Disponível em http://www.oki.com/jp/FSC/iris/en/index.html. Acesso em 04 de Janeiro de 2008.

PARK K.R. New automated iris acquisition method. Appl Opt. 2005 Feb 10; 44(5); 713-34.

PAU, Hans. Differential diagnosis of eye diseases.. English Edition. 2 ed. New York:Thieme. 1988.

PAVAN-LANGSTON, Deborah. Manual of ocular diagnosis and therapeutics. 5 ed. Philadelphia: Lippincott Willians\& Wilkins. 2002.

PENA, Sérgio Danilo. Aristóteles, nosso contemporâneo Ciência hoje. Disponível em http://www.cienciahoje.uol.com.br/54575. Acesso em 23 de março de 2007.

Pequena história da individualidade genética. Ciência hoje. Disponível em http://www.cienciahoje.uol.com.br/59470 acesso em 24/03/2007

POTHEN, D. J.; PARMANTO, B. Biometric authentication: privacy protection or invasion? $J$ AHIMA 2001 Jul-Aug; 72(7): 24,26.

PROENÇA H.; ALEXANDRE, L.A. Toward noncooperative iris recognition: a classification approach using multiple signatures. IEEE Trans Pattern Anal Mach Intell. 2007 Apr 29(4): 607-12.

RATHA, Nalini K.; GOVINDARAJU, Venu (editores). Advances in biometrics. New York: Springer-Science+Business Media, 2008.

RICHARDS, Edwards P. Phenotype v. genotype: Why identical twins have different fingerprints? Disponível em http://www.forensic-evidence.com/site/ID/ID Twins.html. Acesso em 04 de maio de 2007.

ROIZENBLATT, Ricardo; SCHOR, P.; DANTE; F.; ROIZENBLATT; J.; BELFORT JÚNIOR, R. Iris recognition as a biometric method after cataract surgery. Biomed Eng Online 2004 jan 283:2 
RUSSEL, Bertrand. História do pensamento ocidental. A aventura dos pré-socráticos a Wittgenstein. Tradução de Laura Alves e Aurélio Rebello. Rio de Janeiro: Ediouro, 2001.

RYAN, Stephen J. editor. Retina, vol. 1. Electronic edition. Boston: Mosby, 1994.

SAMPAIO, Sebastião A.P.; Raymundo M. CASTRO; Evandro A. RIVITTI. Dermatologia Básica, 3 ed.. São Paulo: Livraria Editora Artes Médicas, 1983.

SCHUCKERS, S. A.; SCHIMID, N.A.; ABHYANKAR A.; DORAIRAJ, V.; BOYCE, C. K.; HORNAK, L. A. On techniques for angle compensation in non ideal iris recognition. IEEE Trans Sits Man Cyber. B. Cyber. 2007 Oct; 37(5): 1176-90.

SECURIMETRICS INCORPORATED. Iris Recognition. Disponível em http://www.securimetrics.com/iris/index.html. Acesso em 04 de janeiro de 2008.

SHECAIRA, Sérgio Salomão. Criminologia. São Paulo: Revista dos Tribunais, 2004.

SILVA, Tomaz Tadeu (org.). Identidade e diferença. A perspectiva dos estudos culturais. Petrópolis: Editora Vozes, 2000.

SEVERINO, Antônio Joaquim. Metodologia do Trabalho Científico. 22 ed. rev. ampl. São Paulo: Cortez Editora. 2003.

SHIELDS, M. Bruce. A study guide for glaucoma. Baltimore:Williams \&Wilkins, 1982.

SMITH, A.D., Biometrics based service marketing issues: exploring acceptability and risk factors of iris scans associated with registered travel programs. Int. J. Electron Health 2008;4(1):43-66.

SOBRINHO, Mário Sérgio. Identificação criminal. São Paulo: Revista dos Tribunais, 2003.

TOURINHO FILHO, Fernando da Costa. Manual de processo penal. 4 ed. revista atualizada e aumentada. São Paulo: Ed. Saraiva. 2002.

VACCA, John R. Biometrics technologies and verification systems. Burlington: ButterworthHeinemann, 2007.

VATSA M.; SINGH R.; NOORE A. Improving iris recognition performance using segmentation, quality enhancement, match score fusion, and indexing. IEEE Trans System Man. Cybern. B. Cybern. 2008 Aug.; 38 (4):1021-35. 
VIGLIAZZI, Douglas. Biometria: medidas de segurança. 2 ed.. Florianópolis:Visual Books, 2006.

VELOSO DE FRANÇA, Genival. Medicina legal. 7 ed.. Rio de Janeiro: Ed. Guanabara Koogan, 2004.

VON NOORDEN, Gunter. Atlas of strabismus. 4 Ed. Saint Louis:Mosby, 1983.

WILDE, Oscar. The picture of Dorian Gray. Londres:Penguin Books, 2006.

WOLFF, Eugene. Anatomy of the eye and orbit. Revisão de Roger Warwick. 7 ed. Philadelphia: W.B. Saunders Company, 1976. 


\section{RESUMO}

A presente dissertação aborda o processo de identificação por biometria das estruturas oculares, analisando suas bases biológicas e tecnológicas e sua aplicabilidade e confiabilidade para utilização jurídica. Está dividida em três partes. Na primeira, são analisados aspectos do conceito de identidade em suas diversas acepções e do processo de identificação médico legal por meio da utilização de diferentes métodos. Na segunda, passa-se a estudar a biometria da íris e da retina, abordando suas bases biológicas e tecnológicas. $\mathrm{Na}$ terceira e última parte, estuda-se a aplicabilidade e confiabilidade da biometria ocular para finalidades jurídicas, como método de perícia da identidade. 


\section{SUMMARY}

The purpose of this work is to study the identification process by ocular biometrics, from its biological and technological basis to its forensic and legal system applications. It is divided into three sections. The first section discusses the concept of identity and the identification methods used by forensic professionals. The second section discusses the ocular biometrics methods using iris and retinal traits, emphasizing their biological as well as their technological basis. The third and last section discusses the reliability and applicability of these biometrics modalities as identification methods in legal and forensic issues. 